\title{
ESUSA: U.S. ENDANGERED SPECIES DISTRIBUTION FILE
}

\author{
John Nagy and Charles E. Calef
}

October 1979

NATIONAL CENTER FOR ANALYSIS OF ENERGY SYSTEMS

DEPARTMENT OF ENERGY AND ENVIRONMENT

BROOKHAVEN NATIONAL LABORATORY UPTON, NEW YORK 11973 


\section{DISCLAIMER}

This report was prepared as an account of work sponsored by an agency of the United States Government. Neither the United States Government nor any agency Thereof, nor any of their employees, makes any warranty, express or implied, or assumes any legal liability or responsibility for the accuracy, completeness, or usefulness of any information, apparatus, product, or process disclosed, or represents that its use would not infringe privately owned rights. Reference herein to any specific commercial product, process, or service by trade name, trademark, manufacturer, or otherwise does not necessarily constitute or imply its endorsement, recommendation, or favoring by the United States Government or any agency thereof. The views and opinions of authors expressed herein do not necessarily state or reflect those of the United States Government or any agency thereof. 


\section{DISCLAIMER}

Portions of this document may be illegible in electronic image products. Images are produced from the best available original document. 


\title{
ESUSA: \\ U.S. ENDANGERED SPECIES DISTRIBUTION FILE
}

\author{
John nagy and Charles E. Calef
}

October 1979

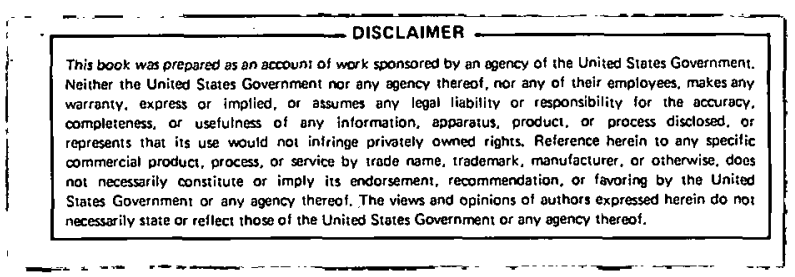

\author{
BIOMEDICAL AND ENVIRONMENTAL ASSESSMENT DIVISION \\ NATIONAL CENTER FOR ANALYSIS OF ENERGY SYSTEMS \\ DEPARTMENT OF ENERGY AND ENVIRONMENT \\ BROOKHAVEN NATIONAL LABORATORY \\ ASSOCIATED UNIVERSITIES, INC.
}

UNDER CONTRACT NO. DE-AC02-76CH00016 WITH THE

UNITED STATES DEPARTMENT OF ENERGY 


\section{DISCLAIMER}

This husk was prepared ao an account of work spunsured by all ayency of the United States Government. Neither the United States Government nor any agency thereof, nor any of their empluyees, makes any warranty, express or implied, or assumes any legal liability or responsibility for the accuracy, completeness, or usefulness of any information, apparatus, product, or process disclosed, or represents that its use would not infringe privately owned rights. Reference herein to any specific commercial prod-

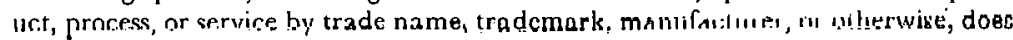
not necessarily constitute or imply its endorsement, recommendation, or favoring by the United States Government or any agency therenf. The views and opinions of authors expressed herein do not necessarily state or reffer.t those of the United States Govcrnment ui any agency thereof.

Printed in the United States of America Available from

National Technical Information Service

U.S. Department of Commerce

5285 Port Royal Road Springfield, VA 22161

Price: Printed Copy $\$ 4$, Microfiche $\$ 3$. 
TABLE OF CONTENTS

$\underline{\text { PAGE }}$

TABLE OF CONTENTS.......................

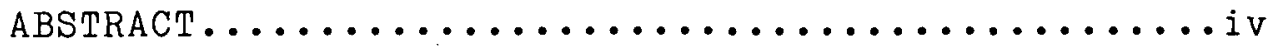

ACKNOWLEDGEMENTS..................... v

I. FILE CHARACTERISTICS.....................

I.1 PHYSICAL.....................

I.2 LOGICAL.......................

II. DATA PRESENTLY ON FILE.................. 2

III. TAXONOMIC GROUP NUMBER................. 4

IV. FEDERAL LEGAL STATUS CODES............... 5

V. TYPES OF RANGE INFORMATION INCLUDED........... 6

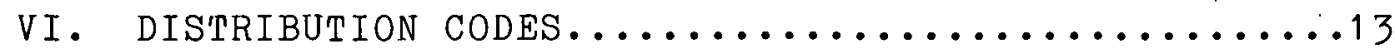

VI.1 FEDERAL INFORMATION PROCESSING STANDARDS...13

VI.2 NON-STANDARD DISTRIBUTION CODES.........15

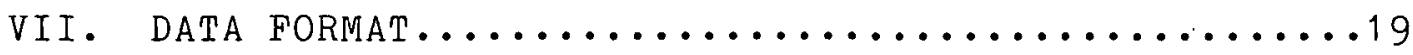

VII.1 A CARD - Common name, Species group, Legal status...................

VII.2 B.CARD - Scientific name, family.......22

VII.3 C CARDS - Designated critical habitat.....23

VII.4 D CARDS - Present range..............24

VII.5 E CARDS - Potential range for possible reintroduction....................

VII.6 F CARDS - Historic range.............26

VII.7 G CARDS - Priorities, Federal Register citations.........................

VII.8 H CARDS - Sources of geographic distribution information.......28 
VIII. SYNONYMS............................. 29

IX. POSSIBLE EXPANSTONS OF FILE............... 31

X. RELATEd DATA FILES....................... 32

XI. SAMPLE PRINTOUTS...................... 33

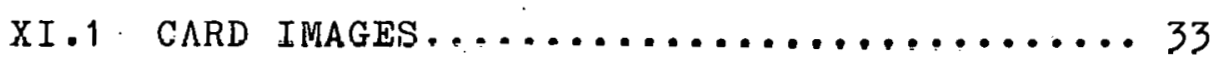

XI.2 ONE PAGE SPECIES INFORMATION DUMP...... 34

$\mathrm{XI} .3$ ONE LINE PER SPECIES SUMMARY......... 35

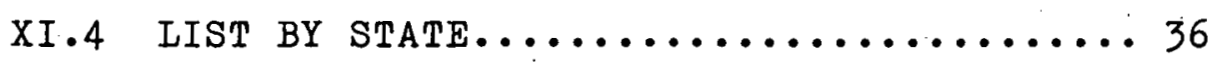

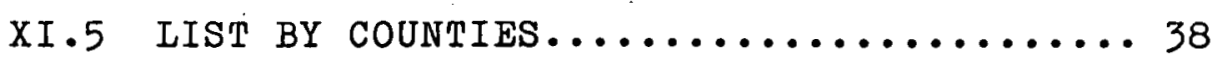

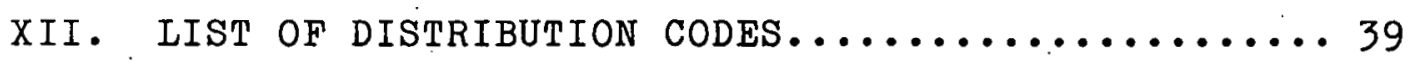

XIII. REFERENCES......................... 64 


\section{ABSTRACT}

This paper describes a file containing distribution data on endangered species of the United States of Federal concern pursuant to the Endangered Species Act of 1973. Included for each species are (a) the common name, (b) the scientific name, (c) the failily, (d) the group (mammal, bird, etc.), (e) Fish and Wildlife Service (FWS) listing and recovery priorities, ( $f$ ) the Federal legal status, ( $g$ ) the geographic distribution by counties or islands, (h) Federal Register citations and (i) the sources of the information on distribution of the species. Status types are endangered, threatened, proposed, formally under review, candidate, deleted, and rejected. Distribution is by Federal Information Processing Standard (FIPS) county code and is of four types: designated critical habitat, present range, potential range, and historic range.

The file has found use in two general ways. The first is to produce simple lists of species, with or withoul selection or ordering by species type, status, or geographic area. Examples have included the enumeration of candidate species within each FWS region ordered by priority and enumeration of species occurring in coastal counties. The second application is any project correlating endangered species with location information expressed by county. Examples are Forest Service or Bureau of Land Management proposed wilderness areas and energy facility siting models. 


\section{ACKNOWLEDGEMENTS}

The idea that the organization of county distribution information on federally listed endangered species combined with similiar information on future energy facilities would be a useful tool in energy planning and environmental assessment was conceived by Laniel Shreeve, now at Northeast Missouri State University. It is from this ground breaking work that the current monster developed.

We were aided in the work of collecting data by. H. Rachel Lederman, a student at Cornell University, and Teresa.Ayres, formerly of the Office of Endangered Species. The project is essentially a computer based information system. Therefore, someone must enter the data into the computer. The bulk of this horrendous task was done with astounding accuracy, not to mention pleasant spirit, by Joan congemi.

Finally, we would like to thank Jodi Earle and Sharon Zuhoski for the preparation of this manuscript, especially the first ninety-nine times. 


\section{FILE CHARACTERISTICS}

\section{1 PHYSICAI CHARACTERISTICS}

\begin{tabular}{|c|c|}
\hline Organization & $\begin{array}{l}\text { Biomedical and Environmental } \\
\text { Assessment Division } \\
\text { Brookhaven National Laboratory } \\
\text { Upton, NY } 11973\end{array}$ \\
\hline Medium & $\begin{array}{ll}\text { type } & \text { punched cards } \\
\text { width } & 80 \text { columns } \\
\text { number used } & 80 \text { columns }\end{array}$ \\
\hline Character code & IBM 026 Punch (.BCD") \\
\hline Control characters & $\begin{array}{l}\text { END-OF-DECK signaled by }-1 \text { in columns } \\
77-78 \text { of an "A" card }\end{array}$ \\
\hline Date of creation. & $\begin{array}{l}\text { updated first week of every calendar } \\
\text { quarter }\end{array}$ \\
\hline Date of obsoléscence & end of each calendar quarter \\
\hline Number of records & $\begin{array}{l}\text { approximately } 30,000 \text { cards } \\
\text { (about } 5,000 \text { species) }\end{array}$ \\
\hline Privacy & no restrictions of any kind \\
\hline
\end{tabular}

\section{I.2 LOGICAL CHARACTERISTICS}

File Name

F1le ID number

File date

File structure

Documentation

Subject

Collating sequence

Record characteristics

Data elements
ESUSA

nonc,

beginning of the current calendar quarter

see section VII

BNL 51129

geographical distribution

of endangered species

see section VII

see section VII

gee eection II 


\section{DATA PRESENTLY IN FILE}

1) Common Name

2) Scientific Name

Liberal use is made of synonyms in parentheses to aid researching species

3) Family

4) Taxonomic Group Code

(See Section III.)

5) Federal Legal Status

(See Section IV.)

6) Distribution by Counties

(See Sections V \& VI.)

A) Designated Critical Habitat

This is an area determined by rulemaking to contain those physical and biological elements necessary for the specie's survival. The data base does not distinguish between final and proposed rulemakings. Refer to the Federal Register references (See 7 Below).

B) Present Range

Exact meaning varies with species grúu and existence of recent field surveys. Discussed further in section $V$.

If the species is believed to be extinct world wide, the word 'extinct' will appear under present.

- range. If the species is extirpatca over its forrer range under U.S. jurisdiction, the word 'extirpated' will appear.

Tho word 'unknown' means that the BNL project does not have definitive reference material on hand (not that nobody anywhere knows).

C) Potential. In the sense of possible re-introduction ? not 'maybe it's there, maybe not'). 
D) Historic Range

7) Federal Register Articles

8) FWS Listing and Recovery Priorities

9) References
Widest known distribution of the species in the past, see section V. for further discussion.

The word 'unspecified' means that an accurate account of the county distribution for that state is unavailable or meaningless (e.g. whales)

Date and page with abbreviations as follows: F Final Rulemaking $P$ Proposed Rulemaking

NR Notice of Review of Status

RS Same as ' $N R$ '

$\mathrm{E}, \mathrm{T}, \ldots$... End angered, Threatened,...

as in section IV.)

$\mathrm{CH}$ Critical Habitat

Examples

PECH = Proposed as E with Critical Habitat

$F D=$ Final Rulemaking to Delete species

A score from 1 (high priority) to 12 (low) determines loosely the relative importance FWS/OES assigns to taxa.

A separate file contains the references upon which the present, potential, and historic range information is based. Numeric entries jn file ESUSA point to the references. 


\section{TAXONOMIC GROUP NUMBER}

Each species is assigned to one of eleven taxonomic groups. The groups, and the English names used to describe them, follow the categories used by the Fish and Wildife Service in the Federal Register and the Code of Federal Regulations. This information is stored as a double digit integer.

\begin{tabular}{cll} 
Group Number & \multicolumn{1}{c}{ Name } & Taxonomic Classification \\
\hline 1 & Mammals & class Mammalia \\
3 & Birds & class Aves \\
4 & Reptiles & class Reptilia \\
5 & Nishoibians & class Amphibia \\
6 & Snalls & other subphylum Vertebrata \\
7 & Clams & claso Gastropoda \\
8 & Crustaceans & class Pelecypoda \\
9 & Insecto & class Crustacea \\
10 & Other andmals & othcr kingdom Animalia \\
11 & Plante & kingdom Plantae
\end{tabular}




\section{FEDERAL LEGAL STATUS CODES}

Each species is assigned to one of eight categories depending on its Federal legal status, if any. This information is stored as a single alphabetic code.

\begin{tabular}{|c|c|c|c|}
\hline Number & Code & Status & Explanation \\
\hline 1 & $\mathrm{E}$ & Endangered & $\begin{array}{l}\text { Listed by a final } \\
\text { rulemaking }\end{array}$ \\
\hline 2 & $\mathrm{~T}$ & Threatened & $\begin{array}{l}\text { Listed by a final } \\
\text { rulemaking }\end{array}$ \\
\hline 3 & $B$ & $\begin{array}{l}\text { Both Endangered } \\
\text { and Threatened }\end{array}$ & $\begin{array}{l}\text { Listed by a final } \\
\text { rulemaking. Status } \\
\text { of an individual } \\
\text { either endangered or } \\
\text { threatened depending } \\
\text { on geographic } \\
\text { location. }\end{array}$ \\
\hline 4 & $\mathrm{P}$. & Proposed & $\begin{array}{l}\text { Proposed for listing } \\
\text { in Federal Register }\end{array}$ \\
\hline 5 & $\mathrm{~V}$ & Notice of Review & $\begin{array}{l}\text { Review of status } \\
\text { announced in Federal } \\
\text { Register }\end{array}$ \\
\hline 6 & D & $\begin{array}{l}\text { Delisted } \\
\text { Deleted }\end{array}$ & $\begin{array}{l}\text { Removed from list in } \\
\text { Federal Register by } \\
\text { virtue of } \\
\text { 1) Extinction } \\
\text { 2) No longer } \\
\text { threatened } \\
\text { 3) Included in a } \\
\text { highcr taxon }\end{array}$ \\
\hline 7 & $\mathrm{~J}$ & Rejected & $\begin{array}{l}\text { Rejected for listing } \\
\text { and so announced } \\
\text { in Federal Register }\end{array}$ \\
\hline 8 & blank & Candidate & $\begin{array}{l}\text { Species being } \\
\text { considered by FWS } \\
\text { staff for possible } \\
\text { proposal for listing. } \\
\text { No official Federal } \\
\text { status. }\end{array}$ \\
\hline & & $-5-$ & \\
\hline
\end{tabular}




\section{TYPES OF RANGE INFORMATION INCLUDED}

In ESUSA, the Brookhaven endangered species data base, three general types of range information are recorded: present range, historical range, and potential range. Within each of these broad groups are sub-categories differentiated by more or less fine shades of meaning. Present range for one species of animal may not have exactly the same meaning ds present range for another. I'he following paragraphs spell out the various meanings given to species' ranges, and why they are appropriate to certain species but not to others.

\section{PRESENT RANGE}

General considerations: What is the information one would like to convey, ideally for present range, assuming for the moment that that information is actually obtainable? Perhaps present range should be those counties actually harboring a species at a given moment in time--the present. Such information could be obtained, but only through a quick, expensive, and exhaustive survey of all possible counties of occurence. But even if such an "instantaneous" perfect survey could be accomplished, it would reveal, for some species, areas suitable for habitation which at the moment are unoccupied. A mobile or transient species might recolonize the area in the space of a few years, so should not such areas be considered present range? The definition of present range is arbitrary; there 
is no such thing as a true present range, an immutable ideal that we can only approximate. Present range reflects what an investigator wants from such information. Some of the present range categories, or definitions we have used in ESUSA are:

1. Present range based on post-1960 observations.

In this category are included only those counties for which an observation or collection of the species has been made since 1960. The trouble with this definition is that it underestimates the actual number of counties which may be harboring the species now. The reason is simply that for many rare species there are few biologists actively researching and collecting them. Hence, in the short period of roughly 20 years since 1960, it is almost certain that some portions of the present range will have gone unsampled. For certain species it is found that collections of that species have, over the years, been made in dozens of counties, but since 1960 in only a few. One can interpret this two ways, (1) the former range has shrunk to only a few counties, or (2) many of the areas for which older collections exist have simply not been recently recollected, and the species probably still lives there. In the absence of expert knowledge, there is no good way to decide between the two possibilities. If one chooses the first interpretation he can document exactly the few counties he lists as "present" because recent collection records exist for each county. But he may well be underestimating the 
true present range. The second interpretation which includes all observations (even old ones) as present range may come closer to approximating the actual present range, but is certain to include counties where the animal has been - extirpated.

\section{Interpolated present range.}

This type of range is used by authors of field guides. They have records of occurrence of a species spotted over a wide area on the map. The range however includes not only those counties with observations, but intervening counties as well. In other words, the range map as finally drawn has no holes in it formed by areas without observations. It is assumed by the author that the animal might occur anywhere within the range even though it has actually been collected at only a few points within this range. It seems to us a. suitable range, especially for animals that are rare but not so rare as to be at the point of extinction. such animals will have generally known ranges but will not be so common as to be constantly seen and recorded in every county throughout their range. If an animal is small, secretive, nocturnal or otherwise poorly known, the interpolated range is probably appropriatc. Many reptiles, for example, the Eastern indigo snake and Gila monster, have their present ranges included in the data base as interpolated range. This is following the example set in the Catalog of American Amphibians and Reptiles, which presents interpolated range 
maps and was used as information on a number of reptiles and amphibians.

Note however, that an interpolated range may well include counties where the animal has not and never will occur due to the absence of appropriate habitat. This shortcoming of interpolated range will be more acute for animals with narrowly defined habitat requirements, especially if such habitats are rare and patchy. An animal requiring sphagnum bogs may be widespread across the eastern U.S., but filling in all the counties between observations is inaccurate. The animals distribution is actually insular, not interpolated. Deciding. whether or not to apply interpolated range should be left, finally, to specialists in the Office of Endangered Species.

Highly mobile animals present problems in defining their present range. If a wolverine is spotted in Ouray County, Colorado, he may be in Gunnison County day after tomorrow. Active far ranging animals may make use of several counties, but because of their rarity be observed in only a few occasionally. The extreme example of mobility is birds. Mobile animals will of necessity have "blurry" ranges. Or put another way, a map of spotty sightings should probably have the intervening holes filled in. Another related problem involves those animals which range widely part of the year but spend a critical part of their lives in one well defined area, usually for breeding or wintering. Ninety. four percent of the population of the 
Indiana bats hibernate in only 13 caves. In summer the population disperses and observations may be made throughout the eastern U.S. It is useful to consider such an animal as having two "present" ranges: (1) a dispersed range and (2) an aggregated or concentrated range. We have separated, where applicable the present range of species into these two subcategories. Where a single present range is given the animal is assumed to live there year around.

Birds illustrate the same problem. Their nesting grounds and wintering range would be considered "aggregated ranges" while their transient, migration paths would be the equivalent of "dispersed" range.

Implicit in these two types of present range for mobile animals is that aggregated or nesting range is more critical to the species survival. More time is spent in that range and the environmental characteristics found there are rare, or at least demanded by the species. For thid reason aggregated, i.e., breeding, overwintering areas etc. have often been designated as official critical habitat by FWS. HIST $\underline{\text { ORIC RANGE }}$

Under this heading we include all U.S. areas that have ever been known to contain the species in question. Often historic ranges far exceed the area now inhabited by the species. The grizzly bear and gray wolf once inhabitated immense areas of the 48 states but are now found in only a few counties: The same is true of certain wide ranging endangered fish and mollusks: where they once populated 
whole river basins they now occur in a handful of undisturbed reaches of tributaries.

For endangered species which were only recently discovered or described (within the last 20 years) there is of course no record of their occurrence in the distant past. For such a species its "historic" range is the same as its "present". Of course its actual historic extent may have been greater but as the species was unknown there is no way of knowing.

A similar situation applies to subspecies. In the . absence of definitive information we assume their historic and present ranges are the same. This is because subspecies occur in geographically distinct areas within the species' range and because of isolation or natural selection pressure presumably always did.

The exact interpretation of the historic range given in the data base also depends on the source of the information. In some cases the actual historic range will tend to be overestimated. Thio occuro, for example, when broad interpolated range maps are used. The mammal historic distribution depends heavily on Hall and Kelson's Mammals or North America. Many counties included within the by range map whose boundaries are defined marginal records do not contain, and never have contained, suitable habitat for the species in question. On the other hand some reference works may underestimate the range. This is the case with published museum or herbarium acarcheo. The actual range 
may be larger; specimens have just not been duly entered in an official repository for one reason or another. In summary, take care in attaching a definite meaning to any particular range datum. 


\section{DISTRIBUTION CODES}

\section{1 FEDERAL INFORMATION PROCESSING STANDARDS}

The bașic geographical distribution unit used for the U.S. in the data base is the county. Each county has a unique five digit number associated with it. These numbers are taken from references (1) and (2) herein.

Each county's five digit number can be divided into two parts. The first two digits correspond to a state and the final three to the county within a state. Table 1 gives the state numbers, the two-letter postal code for the states used in reports generated from the data base, and the state names. Section XII: lists each distribution code used. The state of Alaska is not divided into counties (or parishes) as such. For Alaska, the division codes of FIPS PUB 6-2. (Ref. 1 herein): are used. In addition, many distribution codes were made up which are not part of the standards, references (1) or (2). These are described and listed in the following section VI.2 and XII.

For species with non-U.S. distribution, the country is the basic unit. Reference (3) assigns to each country a two letter code. For example, Mexico is MX. This system is translated into the five digit system by translating the two Ietters into two double digit numbers corresponding to their position in the English alphabet and adding the number 8 to the beginning. For example, Mexico becomes 81324 . 
Table 1

STATE CODES

$\begin{array}{lll}01 & \text { AL } & \text { Alabama } \\ 02 & \text { AK } & \text { Alaska } \\ 03 & \text { AS } & \text { American Samoa } \\ 04 & \text { AZ } & \text { Arizona } \\ 05 & \text { AR } & \text { Arkansas } \\ & & \\ 06 & \text { CA } & \text { California } \\ 07 & \text { CZ } & \text { Canal Zone } \\ 08 & \text { CO } & \text { Colorado } \\ 09 & \text { CT } & \text { Connecticut } \\ 10 & \text { DE } & \text { Deleware } \\ & & \text { : } \\ 11 & \text { DC } & \text { District of Columbia. } \\ 12 & \text { FL } & \text { Florida } \\ 13 & \text { GA } & \text { Georgia } \\ 14 & \text { GU } & \text { Guam } \\ 15 & \text { HI } & \text { Hawaii } \\ 16 & \text { ID } & \text { Idaho } \\ 17 & \text { IL } & \text { Illinois } \\ 18 & \text { IN } & \text { Indiana } \\ 19 & \text { IA } & \text { Iowa } \\ 20 & \text { KS } & \text { Kansas } \\ & & \\ 21 & \text { KY } & \text { Kentucky } \\ 22 & \text { LA } & \text { Louisiana } \\ 23 & \text { ME } & \text { Maine } \\ 24 & \text { MD } & \text { Maryland } \\ 25 & \text { MA } & \text { Massachusetts } \\ 26 & \text { MI } & \text { Michigan } \\ 27 & \text { MN } & \text { Minnesota } \\ 28 & \text { MS } & \text { Mississippi } \\ 29 & \text { MO } & \text { Missouri } \\ 30 & \text { MT } & \text { Montana } \\ 31 & \text { NE } & \text { Nebraska } \\ 32 & \text { NV } & \text { Nevada } \\ 33 & \text { NH } & \text { New Hampshire. } \\ 34 & \text { NJ } & \text { New Jersey } \\ 35 & \text { NM } & \text { New Mexico } \\ & & \\ & \end{array}$

36 NY New York

37 NC North Carolina

38 ND North Dakota

39 OH Ohio

40 OK OKlahoma

41 OR Oregon

42 PA Pennsylvania

43 PR Puerto Rico

44 RI Rhode Island

45 SC South Carolina

46 SD South Dakota

47 TN Tennessee

48 T.X Texas

49 UT Utah

50 VT Vermont

51 VA Virginia

52 VI Virgin Islands

53 WA Washington

54 WV West Virginia

55 WI Wisconsin

56 WY Wyoming

*60 AS American Samoa

*61 CZ Canal Zone

62 US Canton \& Enderbury Is.

*66 GU Guam

67 US Inhnston Atoll

71 US Midway Islands

*72 HR Puertu Rico

75 US Trust Territories

76 US Misc. Caribbean

77 US MIsc. Pacific

*78 VI Virgin Islands

79 US Wake Is land

8x foreign countires

99 extinct/extirpated

*Repeats. Codes 03, 07, 14, 43, and 52 used. 


\section{VI.2 NON-STANDARD DISTRIBUTION CODES}

The county codes contained in FIPS PUB 6-2 (ANSI X3.31-1973) were inadequate. Distribution at the county level was especially inappropriate for many islands (consider, for example, the California channel islands). Additional non-county codes have been defined arbitrarily and used which do not correspond one-to-one with any county. Programs, other than BNL's endangered species routines, may have trouble analyzing the data if the additions are not accounted for.

Table 2, following, lists partially the codes defined by the BNL Endangered Species Project and gives the FIPS code and county, if any, in which the sub-county area occurs. See Section XIII for the complete list of distribution codes. 
Table 2

SPECIAL DISTRIBUTION CODES DEFINED BY BNL ENDANGERED SPECIES PROJECT

\begin{tabular}{|c|c|c|c|c|}
\hline $\begin{array}{l}03000 \\
03001 \\
03003 \\
03005 \\
03009\end{array}$ & $\begin{array}{l}\text { AS } \\
\text { AS } \\
\text { AS } \\
\text { AS } \\
\text { AS }\end{array}$ & $\begin{array}{l}\text { American Samoa } \\
\text { Manua } \\
\text { Rose and Sand Islar } \\
\text { Tutuila } \\
\text { Other AS }\end{array}$ & & \\
\hline $\begin{array}{l}06201 \\
06203 \\
06205 \\
06207 \\
06209 \\
06211 \\
06213 \\
06215\end{array}$ & $\begin{array}{l}\text { CA } \\
\text { CA } \\
\text { CA } \\
\text { CA } \\
\text { CA } \\
\text { CA } \\
\text { CA } \\
\text { CA }\end{array}$ & $\begin{array}{l}\text { Anacapa Islands } \\
\text { San Clemente I. } \\
\text { San Miguel I. } \\
\text { San Nicolas I. } \\
\text { Santa Barbara I. } \\
\text { Santa Catalina I. } \\
\text { Santa Cruz I. } \\
\text { Santa Rosa I. }\end{array}$ & $\begin{array}{l}\text { In } \\
\text { In } \\
\text { In } \\
\text { In } \\
\text { In } \\
\text { In } \\
\text { In } \\
\text { In }\end{array}$ & $\begin{array}{l}\text { 061.11/Ventura } \\
\text { 06037/Los Angeles } \\
\text { 06083/Santa Barbara } \\
\text { 06111/Ventura } \\
\text { 06083/Santa Barbara } \\
\text { 06037/Los Angeles } \\
\text { 06083/Santa Barbara } \\
\text { 06083/Santa Barbara }\end{array}$ \\
\hline 12201 & FL & Keys (Monroe Part) & In & 12087/Monroe \\
\hline $\begin{array}{l}15011 \\
15013 \\
15015 \\
15017 \\
15018 \\
15019 \\
15020 \\
15021 \\
15022 \\
15023 \\
15025 \\
15026 \\
15027 \\
15029 \\
15031 \\
15033\end{array}$ & $\begin{array}{l}\mathrm{HI} \\
\mathrm{HI} \\
\mathrm{HI} \\
\mathrm{HI} \\
\mathrm{HI} \\
\mathrm{HI} \\
\mathrm{HI} \\
\mathrm{HI} \\
\mathrm{HI} \\
\mathrm{HI} \\
\mathrm{HI} \\
\mathrm{HI} \\
\mathrm{HI} \\
\mathrm{HI} \\
\mathrm{HI} \\
\mathrm{HI}\end{array}$ & $\begin{array}{l}\text { Hawaii I. } \\
\text { Kahoolawe I. } \\
\text { Kauai I. } \\
\text { Kaula I. } \\
\text { Kure I. } \\
\text { Lanai I. } \\
\text { Laysan I. } \\
\text { Leeward Islands } \\
\text { Lisianski I. } \\
\text { Maui I. } \\
\text { Molokai I. } \\
\text { Necker I. } \\
\text { Nihoa I. } \\
\text { Ni ihau I. } \\
\text { Oahu I. } \\
\text { Pearl/Hermes }\end{array}$ & $\begin{array}{l}\text { In } \\
\text { In } \\
\text { In } \\
\text { In } \\
\text { In } \\
\text { In } \\
\text { In } \\
\text { In } \\
\text { In } \\
\text { In } \\
\text { In } \\
\text { In } \\
\text { In } \\
\text { In } \\
\text { In } \\
\text { In }\end{array}$ & $\begin{array}{l}15001 / \text { Hawai } \\
15009 / \text { Maui } \\
15007 / \text { Kauai } \\
15007 / \text { Kauai } \\
\text { No County } \\
15009 / \text { Maui } \\
\text { No County } \\
\text { No Couny } \\
\text { No County } \\
15009 / \text { Maui } \\
15009 / \text { Maui } \\
\text { No County } \\
\text { No County } \\
15007 / \text { Kauai } \\
15003 / \text { Honolulu } \\
\text { No County }\end{array}$ \\
\hline 26201 & MI & Isle Royale & In & $26083 /$ Keweenaw \\
\hline & $\mathrm{NC}$ & Outer Banks & In & Many Countiea \\
\hline
\end{tabular}


Table 2 (continued)

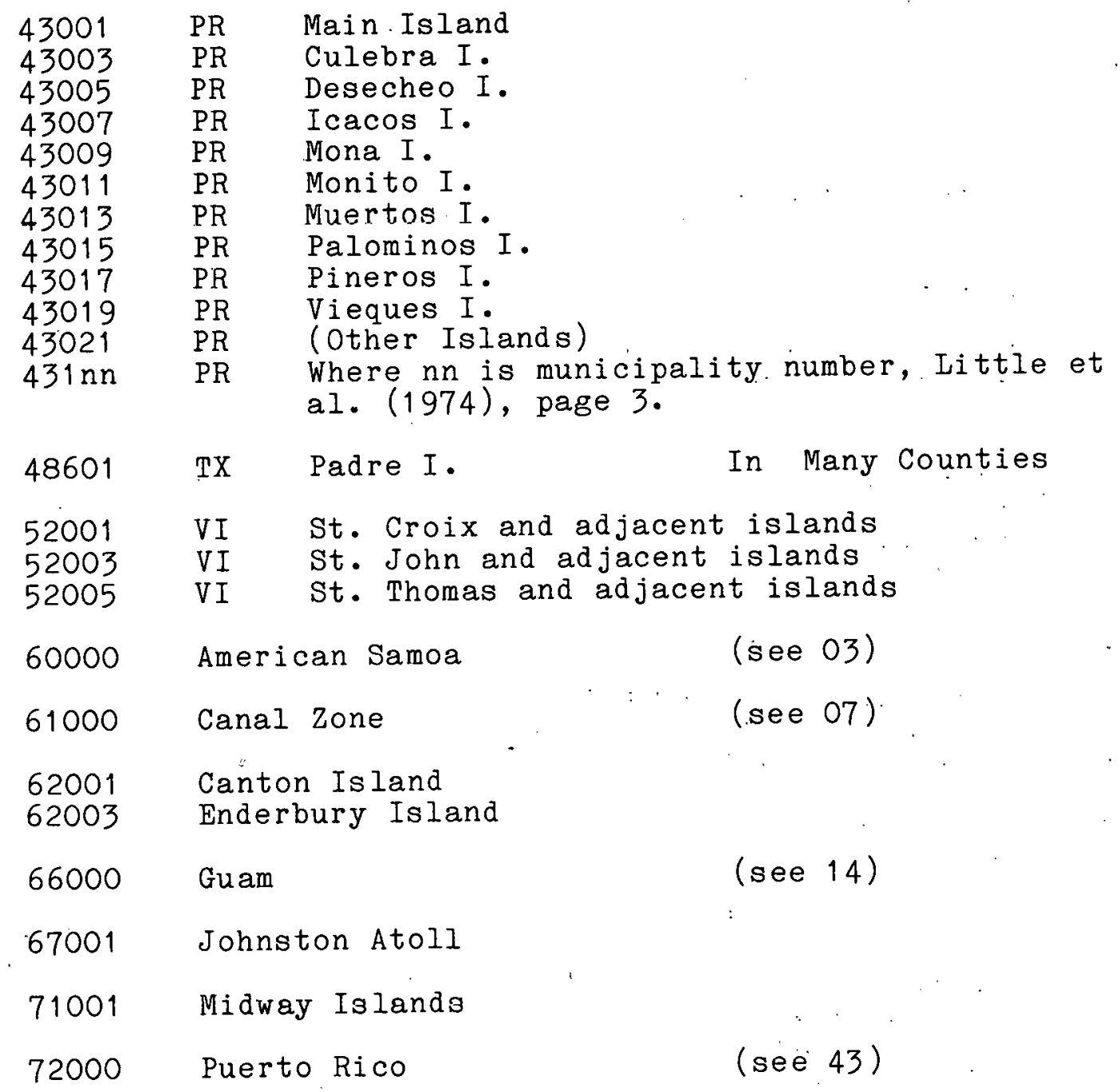


Table 2 (continued)

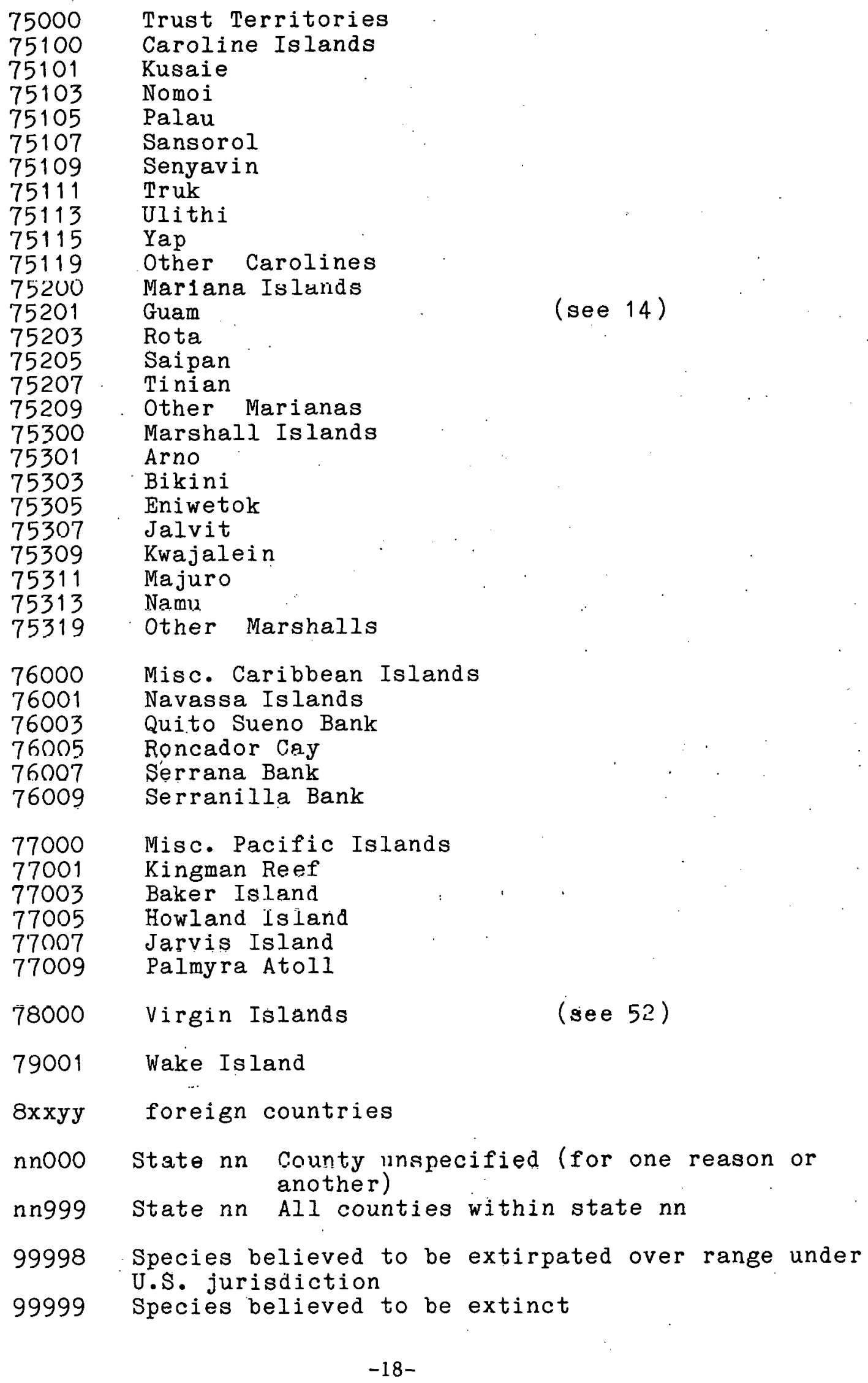




\section{DATA FORMAT}

\section{(1) Primary Data Base}

The primary data base (ESUSA) is 80-column card images. Each card uses columns 1-7 for collation. The first column gives the card type. The second column gives the sequence number within a multiple group of cards of the same type for the same species. The third column is used for a flag indicating whether another card of the same type follows. Columns 4-7 contain a number (essentially random) unique to the species. If and when the number of species reaches 9999, the authors are leaving the field." The remaining 73 columns contain the data whose format depends on the type of data. The following pages describe the content and format of each type of data card.

\section{(2) Secondary Data Files}

The structure of the primary data described above is quite logical from the stand point of the data compiler in terms of ease of additions and corrections. However it is inefficient in terms of (a) disk or central memory storage and (b) central processor time use required by analysis prograns. Therefore secondary data files are usually generated which are geared to efficient use by analysis programs.

The most often used secondary files have the non-distribution information stored as tables. Programs 
quickly run down a column of the tables testing a variable for the condition desired, e.g. all mammals. Other information is then available along the row where the condition is satisfied. The distribution information is stored as a linear string where each word contains (a) a number which points to the table and indicates the species to which the word applies, (b) a distribution code, and (c) an "on-off" 4-digit pattern corresponding to the four types of range information. One standard secondary file has the table and string ordered taxonomically. Another has the string ordered geographically. The file selected for input for analysis depends on the logical structure of the program run. Other files have been created which filter and reorder the data according to taxonomic group, status, and/or geographic region for special projects.

(3) General Purpose Software

Software has been written to query the data files. Control cards specify the groups and statuses of interest. Another control card specifies the states desired or the programs can refer to a list of distribution oodes corresponding, for example, to coastal counties, coal mining counties, etc. Finally, the information can be printed anywhere from one line per species with selected data to multiple page dumps of all data on a species. 


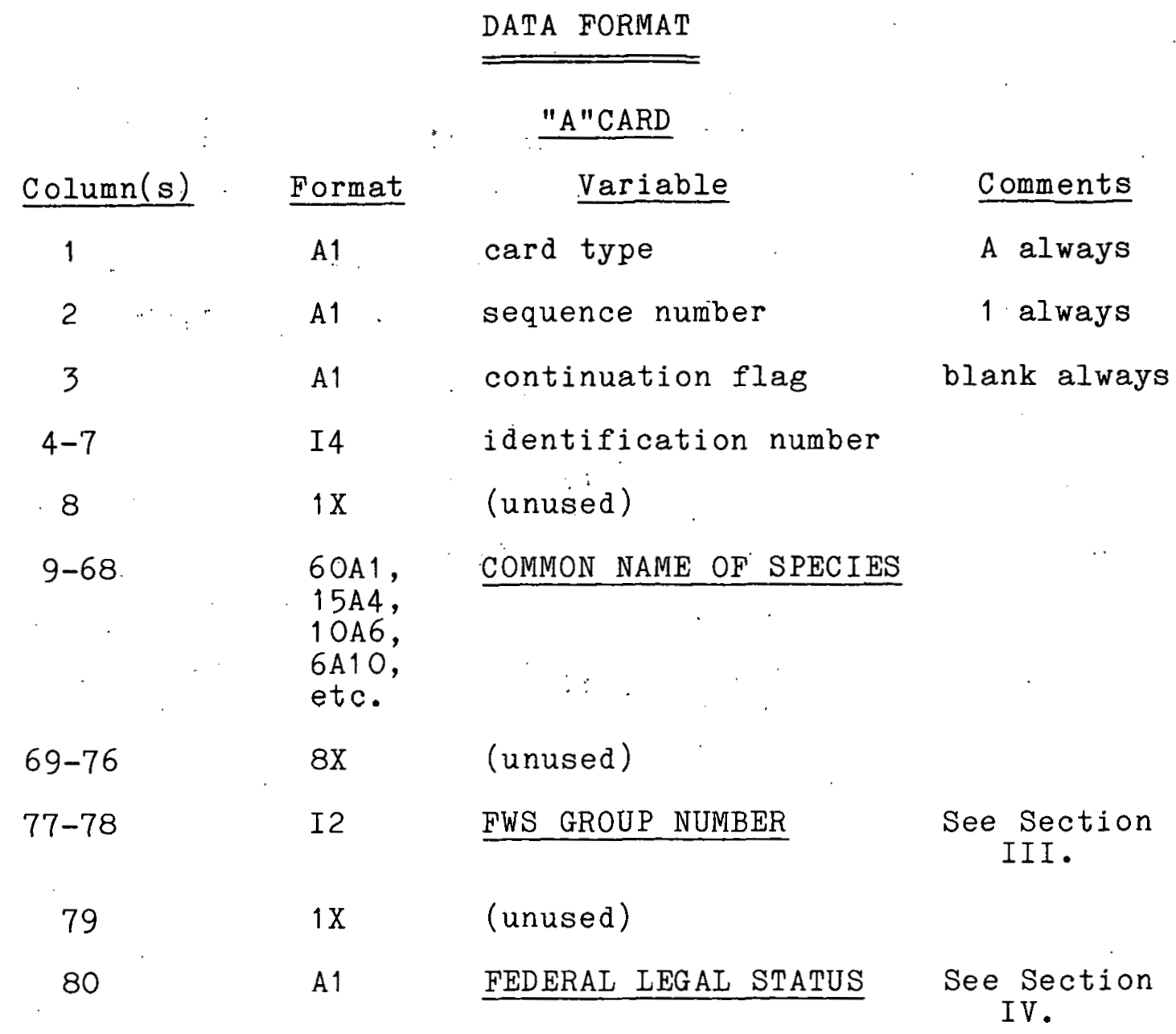


"B" CARD

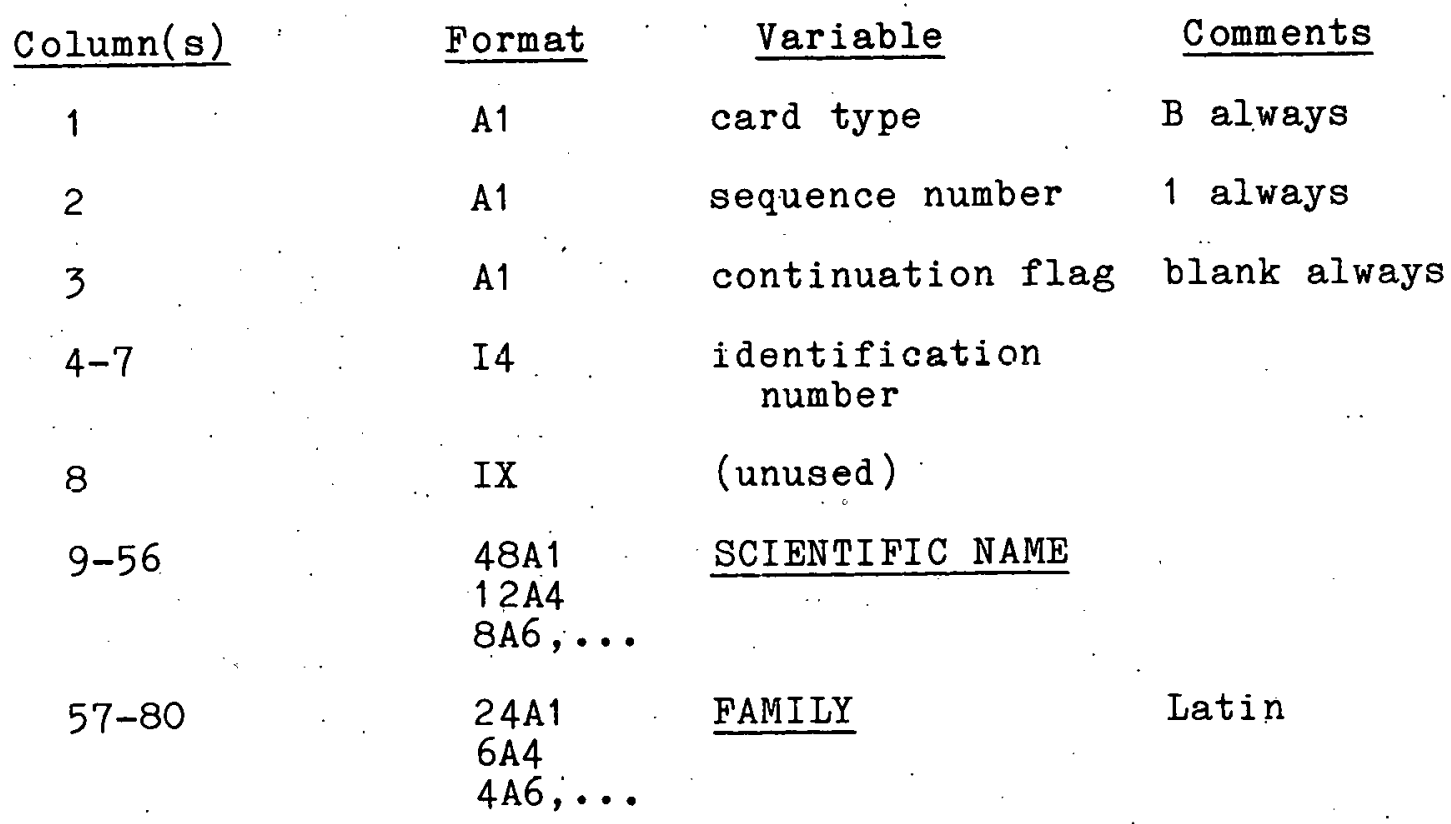


$\because " \mathrm{C} "$ CARD--CRITICAL HABITAT

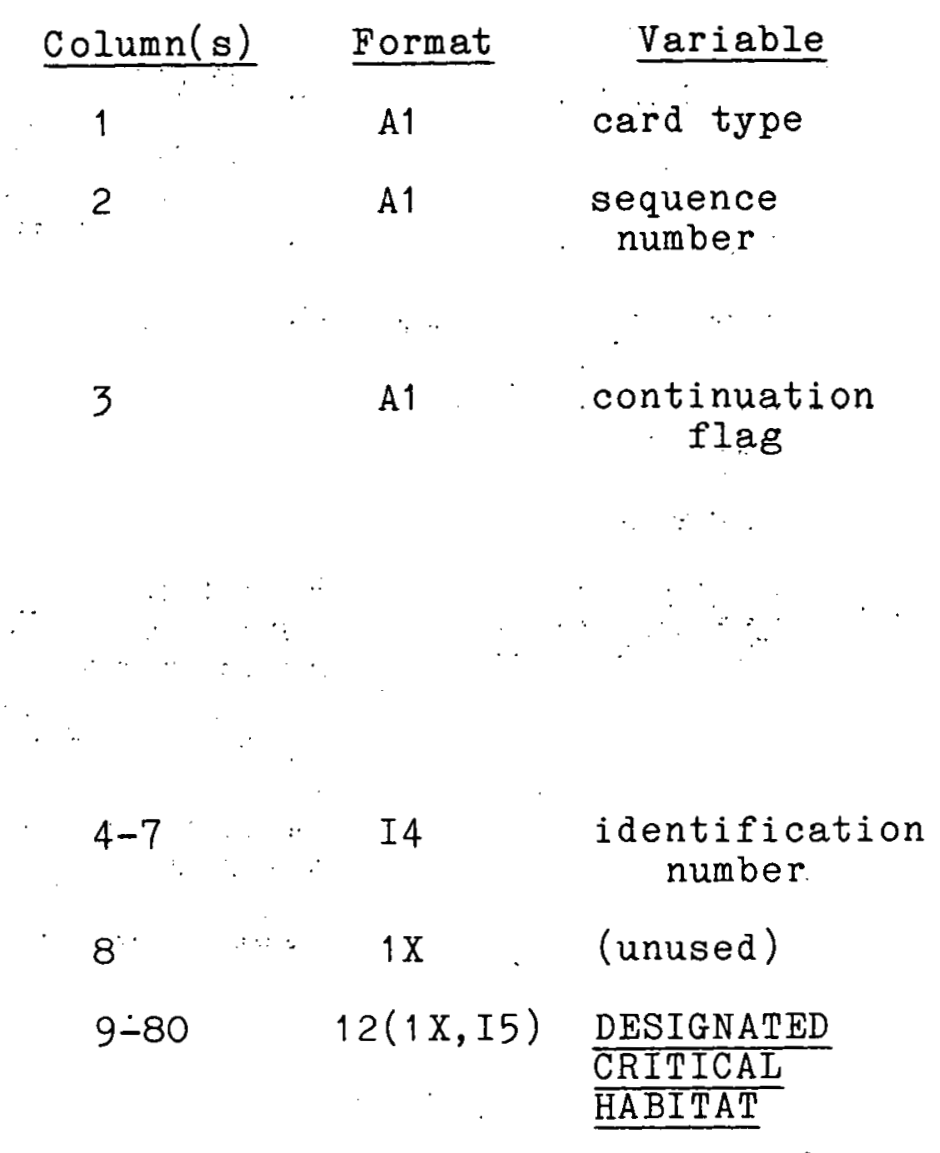

Comments

C always

1-9, A-Z, + sequences series of cards when more than one needed $(+$ after 35 th card)

blank = no card follows

* = more information of same type follows

(a sequence of cards will have * in column 3 except for the last)

FIPS code of counties which contain federally listed or proposed "critical habitat" 
"D" CARD--PRESENT DISTRIBUTION

\begin{tabular}{|c|c|c|c|c|}
\hline Column(s) & & Format & Variable & Comments \\
\hline 1 & & $A 1$ & card type & D always \\
\hline 2 & : & $\mathrm{A} 1$ & sequence number & (as for "C" card) \\
\hline 3 & & $\mathrm{~A} 1$ & continuation flag & (as for "C" card) \\
\hline $4-7$ & & I4 & $\begin{array}{l}\text { identification } \\
\text { number }\end{array}$ & \\
\hline 8 & & $1 \mathrm{X}$ & (unused) & \\
\hline $9-80$ & & $12(1 \mathrm{x}, \mathrm{I5})$ & $\begin{array}{l}\text { PRESENT } \\
\text { DISTRIBUTION }\end{array}$ & $\begin{array}{l}\text { FIPS code of } \\
\text { counties in U.S. } \\
\text { which contain } \\
\text { members of the } \\
\text { listed species } \\
\text { at some time } \\
\text { during the } \\
\text { seasons. }\end{array}$ \\
\hline & & & & (see section $V_{.}$) \\
\hline
\end{tabular}




\section{"E" CARD--POTENTIAL DISTRIBUTION}

\begin{tabular}{|c|c|c|c|}
\hline Column(s) & Format & Variable & Comments \\
\hline 1 & A1 & card type & E always \\
\hline 2 & A1 & sequence number & (as for "C" card) \\
\hline 3 & A1 & continuation flag & (as for "C" card) \\
\hline $4-7$ & I4 & $\begin{array}{l}\text { identification } \\
\text { number }\end{array}$ & \\
\hline 8 & $1 \mathrm{X}$ & (unused) & \\
\hline $\begin{array}{l}9-80 \\
\because .\end{array}$ & $\begin{array}{l}12(1 \mathrm{X}, \mathrm{I5}) \\
\quad: \quad \therefore \\
\vdots \\
\therefore\end{array}$ & $\begin{array}{l}\text { POTENTIAL } \\
\text { DISTRIBUT ION }\end{array}$ & $\begin{array}{l}\text { FIPS code of } \\
\text { counties which } \\
\text { contain suitable } \\
\text { habitat for } \\
\text { species. List } \\
\text { would include all } \\
\text { those counties in } \\
\text { "present } \\
\text { distribution." }\end{array}$ \\
\hline
\end{tabular}


"F" CARD-FORMER DISTRIBUTION

\begin{tabular}{|c|c|c|c|}
\hline Column(s) & Format & Variable & Comments \\
\hline 1 & A1 & card type & F. always \\
\hline 2 & A.1 & sequence number & (as for "C" card) \\
\hline 3 & $\mathrm{~A} 1$ & continuation flag & (as for "C" card) \\
\hline $4-7$ & 14 & $\begin{array}{l}\text { Idenlification } \\
\text { number }\end{array}$ & \\
\hline 8 & $1 \mathrm{X}$ & (unused) & \\
\hline $9-80$ & $12(1 \mathrm{X}, \mathrm{I5})$ & $\begin{array}{l}\text { FORMER } \\
\text { (HISTORIC) } \\
\text { DISTRIBUTION }\end{array}$ & $\begin{array}{l}\text { FIPS code of } \\
\text { counties which } \\
\text { were believed to } \\
\text { be the original } \\
\text { range of the } \\
\text { species. }\end{array}$ \\
\hline & & & (see section $\left.V_{\text {. }}\right)$ \\
\hline
\end{tabular}


"G". CARD--FEDERAL REGISTER REFERENCES

\begin{tabular}{|c|c|c|c|}
\hline Column(s) & Format & Variable & Comments \\
\hline 1 & A1 & card type & G always \\
\hline 2 & A 1 & sequence number & (as for "C" card) \\
\hline 3 & A1 & continuation flag & (as for "C" card) \\
\hline $4-7$ & I4. & $\begin{array}{l}\text { identification } \\
\text { number }\end{array}$ & \\
\hline $8-11$ & $\begin{array}{c}\text { I3 } \\
\vdots\end{array}$ & $\frac{\text { FWS LISTING }}{\text { PRIORITY }}$ & . \\
\hline $12-14$ & I3 & $\frac{\text { FWS RECOVERY }}{\underline{\text { PRIORITY }}}$ & \\
\hline $15-20$ & $6 x$ & (unused) & \\
\hline $21-80$ & $\begin{array}{l}3 \text { groups, } \\
20 \text { columns } \\
\text { each } \\
\cdots\end{array}$ & $\begin{array}{l}\frac{\text { FEDERAL }}{\text { REGISTER }} \\
\text { REFERENCES }\end{array}$ & $\begin{array}{l}\text { Up to } 3 \\
\text { references per } \\
\text { card in form } \\
\text { mm/dd/yy/(ppppp)ABCDE } \\
\text { where } \\
\text { mm = month } \\
\text { dd }=\text { day } \\
\text { yy = year } \\
\text { ppppp = page } \\
\text { ABCDE = some sort } \\
\text { of description } \\
\text { such as PTCH } \\
\text { "proposal for } \\
\text { listing as } \\
\text { threatened with } \\
\text { critical } \\
\text { habitat." }\end{array}$ \\
\hline
\end{tabular}




\section{"H" CARD--LITERATURE SOURCES}

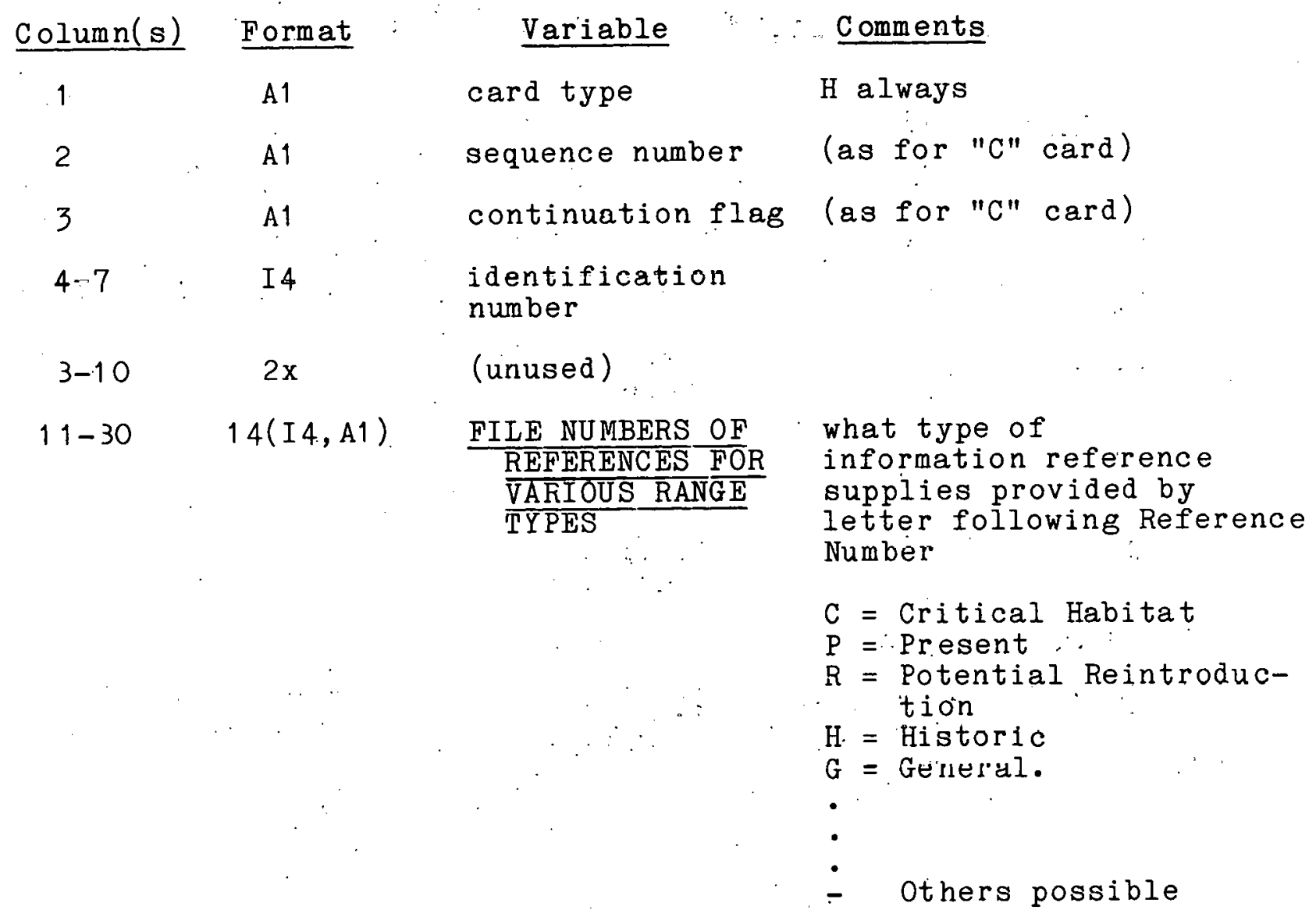




\section{SYNONYMS}

Often a species is referred to in the literature by more than one scientific name. The same applies to families. This can cause confusion among those not intimately familiar with the taxon. In the case of eight plant families, either of two names is allowable under botanical nomenclature rules. For example, the words Asteraceae and Compositae are interchangeable. Confusion also can arise because of the on-going rivalry between "lumpers" and "splitters". For example, should the Amaryllidaceae have family status of their own, or are they a sub-group of the Liliaceae. Finally, name changes occur because of increased understanding of the taxon or, trivially, another name has been shown to have priority. Examples are the downgrading of the Mexican duck Anas diazi to a subspecies, Anas platyrhynchos diazi, of the common mallard, and the placement of certain North American water shakes Ifl the genus' Nerodia rather than Natrix.

At the present time synonyms are handled in an unsatisfactory manner in the data base. If room exists on the card, the synonym appears in parentheses after the equivalent or accepted taxon name, for example, Nerodia (Natrix) fasciata taeniata, Frasera idahoensis (albicaulis var. idahoensis) and Arecaceae (Palmae). 
In the future synonyms will be stored separately on aditional type "B" data cards. Authors of the taxa will be added to the scientific names, and class and order will be specified as well as family. 


\section{POSSIBLE EXPANSIONS OF FILE}

1) State lists of rare and endangered species

2). Non-U.S.A. species and other. laws

a) Endangered Species Act of 1973 listings

b) The Convention on Trade in Endangered Species of Wild Fauna and Flora

c) Migratory Bird Treaty Act

d) Marine Mammal Protection Act

e): Convention on Nature Protection and Wildlife Preservation in the Western Hemisphere

3) Preferred habitat--for correlation with wilderness proposals and restocking plans

4) Population, size and trends

5) Threat types

6): Synonymy

7) Taxonomic author

8) Sub-county disaggregation of distribution. For example,

(a) by Minor Civil Divisions (MCD)

(b) by habitat 


\section{RELATED DATA FILES (available at BNL)}

1) Energy Atlas

2) Future facilities

3) County and State names

4) Water Resource Council

5) Taxonomy

6) Bibliography
Energy budgets, emissions and demographic data by county for 1972 .

Type, opening date, capacity, county of new and expanded energy facilities.

Relates FIPS code to twucharacter post office state abbreviation and ten-character county name.

Relates FIPS codes to Water Resource Council subareas and aggregated subareas.

A file in development continaing taxonomic relationships of plants and animals down to subfamily level.

A file of literature citations for sources of information on geographic distribution of species.' The sources are numbered and correspond to the cntries on $H$ cards in the file ESUSA. 


\section{ESUSA CARD IMAGES}

Al 1194 AMPHIUMA, ONE-TOED

B! 1194 AMPHIUMA PHOLETER

4

C1 1194

DI*1194

D2 1194

E1 1194

$F_{1} * 1194$

$\mathrm{F} 21194$

$\begin{array}{lrr}\text { G1 } & 1194 & 5 \\ \text { A1 } & -1 & \text { COQUI, GOLDEN }\end{array}$

$12013 \quad 12029 \quad 12037 \quad 1203912045 \quad 12063 \quad 12065 \quad 12067 \quad 12073 \quad 12075 \quad 12077 \quad 12079$ $12091 \quad 12123 \quad 12129 \quad 12131 \quad 13131 \quad 13275$

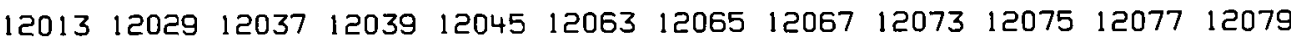
$\begin{array}{lllllll}12091 & 12123 & 12129 & 12131 & 13131 & 13275\end{array}$

COQUI, GOLDEN

-1 ELEUTHERODACTYLUS JASPERI

LEPTODACTYLIDAE

C1 -143000

DI - 1

El -1

$F_{1}-1 \quad 43000$

G1 - 1 - 5

A1 1164 FROG, CHORUS, ILLINOIS

04/05/77(18106)PT $11 / 11 / 77(58756) \mathrm{FTCH}$

BI 1164 PSEUDACRIS STRECKERI ILLINOENSIS

HYL IDAE

4

C1 1164

$\mathrm{D} 1 * 1164$

D2 1164

E1 1164

$F 1 * 1164$

F2 1164

G1 1164

A) 1165

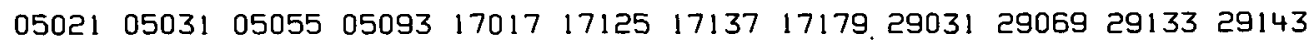
291552920129207

$0502105031050550509317017 \quad 17125 \quad 17137 \quad 17179290312906929133 \quad 29143$ 291552920129207 6

FROG, COOK IS (GUAJON)

ELEUTHERODACTYLUS COOKI LEPTODACTYLIDAE

C1 1165

D1 1165

E1. 1165

F 11165

G1 1165

A1 1166 FROG, ELFIN WOOOS

B! IIG6 ELEUTHERODACTYLUS UNICOLOR LEPTODACTYLIDAE

43000

4

C1 1166

D1 1166

E1 1166

F1 $1166 \quad 43000$

G1 $1166 \quad 5$

A1 237 FROG, LEOPARD, VEGAS VALLEY

B! 237 RANA ONCA

C1 237

D1 237

E1 237

F1 237

G1 237

A1 1167

B1 1167

FROG, RAMOSI BROMELIAD

040003200049000

08/02/77(39121)RS

ELEUTHERO DACTYLUS RAMOSI

LEPTODACTYLID

C1 1167

D1 1167

E1 1167

FI 1167

GI 1167

1

Al 179 FROG. TREE-, PINE BARRENS. (FLORIDA POPULATION)

B1 179 HYLA ANDERSONI

CI $179 \quad 12091$

D) $179 \quad 12091 \quad 12113 \quad 12131$

E I 179

Fi 179

G1 179

A) 795 FROG. TREE-, PINE BARRENS, NJ+NC+SC

$12091 \quad 12113 \quad 12131$

204/05/77(18109)PECH 11/11/77(50754)FECH

195 HYLA ANDERSONII

Cl 795

D1 795

E! 795

$F 1 * 795$

$F 2 * 795$

F3 795

G1 795

132453400134005340073400934011340153402334025340293403337017

$37051370613708537093 \quad 3710137103 \quad 371053710737125 \quad 37133 \quad 3714137153$

371633716537191420454500745025

HYL IDAE 


\section{ONE PAge Information IIUMP}

SALMO CLARKI HENSHAWI

TROUT, CUTTHROAT, LAHONT EN

PRIORITIES-

$=$ LISTING

$07 / 16 ! 75(29864) F T$

04/23/75(17847)PT
SALMOVIDAE

$\mathrm{FISH}$

( 5)

$10=$ RECOVERY

DESIGNATED CRIT HAB

NONEE

PRESENT RANGE

-... PA ALINE $\cdots$

NV MINERAL

POTENTIAL RANGE

$\cdots$ UNKNOWN

HISTORIC RANGE

CA ALPINE

CA SIERFA

NV LANDER

NV CARSCN CIT

PRES HIST

PRES HIST

PRES

HIST
CA MONO

NN WASHOE
CA NEVADA

WY ALBANY
CA PLACER

WY CARBON
SEQUENCE NUMBER

120

IDENT NUMBER (NCC)

$\begin{array}{lllll}\text { CA EL DORADD } & \text { CA LASSEN } & \text { CA MONO } & \text { CA NEVADA } & \text { CA PLACER } \\ \text { N'V CHURCHILL } & \text { NV DOUELAS } & \text { NV ELKO } & \text { NV EUREKA } & \text { NV HUMBOLDT } \\ \text { NV LYON } & \text { NV MINERAL } & \text { NV PERSHING } & \text { NV STÜREY } & \text { NV WASHOE }\end{array}$

CA SIERRA NV HUMBOLDT

SNOW, $c$. (1972) BUREAU OF LAND MANAGEMENT HABITAT MANAGEMENT SERIES FOR RARE OR ENDANGERED SPECIES, REPORT NO. 3, LAHONTAN CUTTHROAT TROUT.

210 MILLEF, R.R., COMPILER (1969) RED DATA BOOK, V. 4-PISCES, IUCN, MORGES, SWITZERLAND.

258 ANON. (19?』) STATUS REPORT ON LAHONTAN CUTTHROAT TROUT, SALMO CLAFKI HENSHAWI, IN ENDANGERED SPECIES OFF ICE. FILES.

266

BEHNKE, R J AND ZARN, M (1975) BIOLOGY AND MANAGEMENT OF THREATENED AND ENDÄNGERED WESTIERN TROJTS, USDA FOREST SERVICE, GENERAL TECHNICAL FEPORT FM-28. 


\section{ONE Line PER SPECIES Summary (example)}

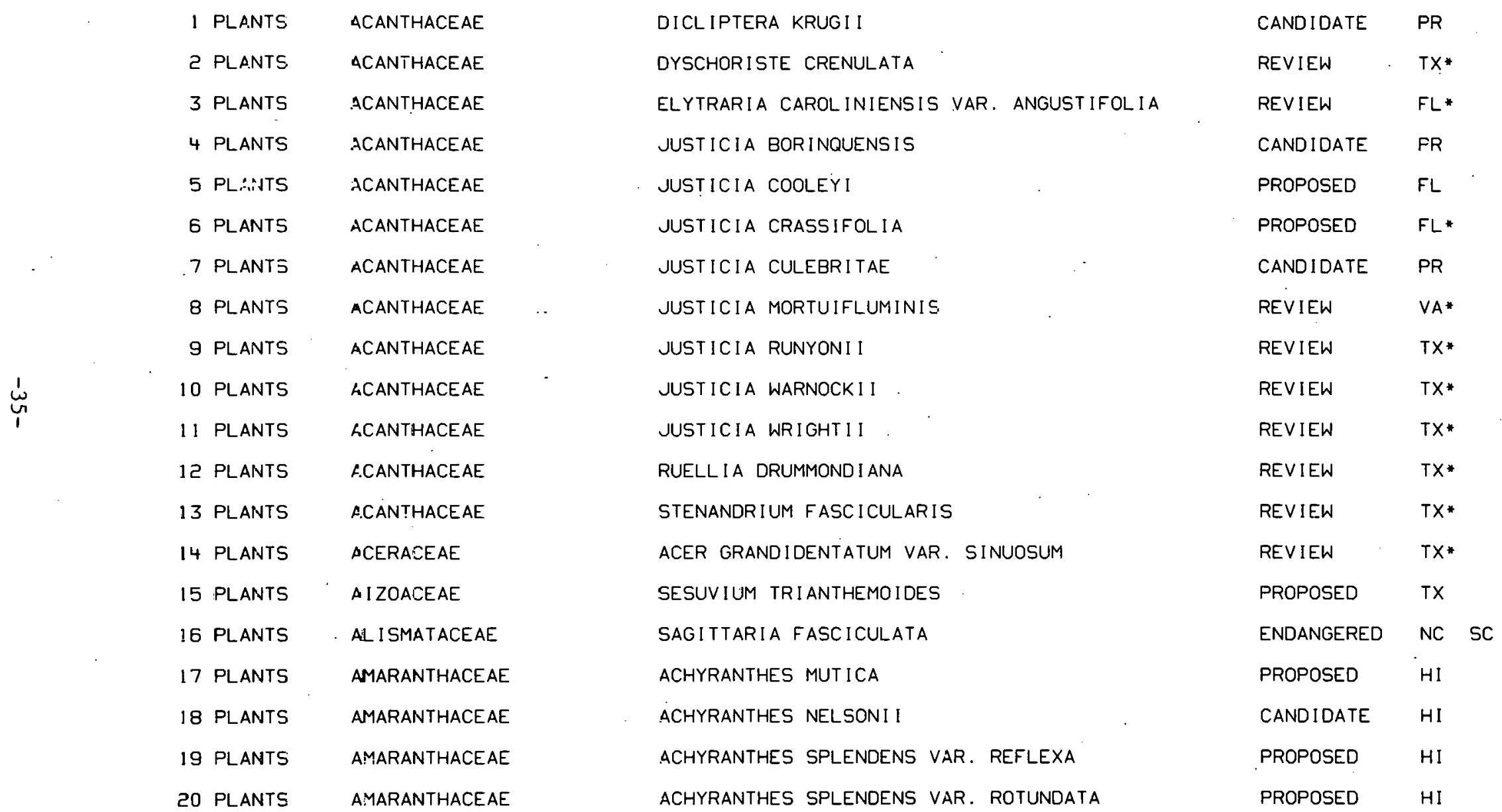




\section{LIST BY STATE}

SELECTION BY STATE

STATUS MASK $11: 1111111$ GROUP MASK 11:11:11111

WISCCNSIN

REGION 3 TWIN CITIES

CRITICAL HABITAT

- PRESENT DISTRIBUTION

- POTENTIAL

. . . HISTOFIC

. . . RECOVERY PRIORITY

. . . . FEDERAL STATLIS

$1-\dot{x}-\dot{x} \quad \dot{7}$ BAT, INCI ANA

$2-x-x \quad 9 \vee$ BOBCAT

$3-x-x$

$5 \vee$ LYNX

$5-x-x$

$12 \checkmark$ MARTEN, EASTERN

$9 \mathrm{~V}$ OTTER, FIVER

3 E CRANE, AHOOPING

$7--x$

$8---x$

3 E CURLEW, ESKIIMO

$9--x$
$10--x$
$11-5$

12 B EAGLE, $3 A$ AD

8 E FALCON, PEREGRINE, $\triangle F C T I C$

SHRIKE, LOGGERHEAD, (EASTERN U.S.)

$12-\bar{x}-x$

i $13-x-x$

WARIKE, LOGGERHEAD, IEASTER

SNAKE, GARTER, CHIOCGO

3 SNAKE, WATER-, KIIRT_ANDIS

5 E CISCO, LONGJAW

$15---x$

$16-x-x$
$17--x$

$18-x-x$

$19-x-x$

$\checkmark$ DARTER, CRYSTAL

3 E MUSSEL, PEARLY, HIGOINS"S EYE

AMPHIPCD, SCUD, WELL, WISCONSIN

$50--x$

$51--x$

$25--x$
$23--x$

$24---x$

$25--x$

$26-x-x$

$57--x$

$28---x$

$30---x$

$31--x$

$32--x$

$33--x$

$34--x$

$36--x$

$37--x$

$38-x-x$

$39=--x$

$40=--x$

V GINSENE. AMERICAN

MILKWEED, MEADIS

THISTLE. DJNE

$P$ BUSH-CLDVER, PRAIFIE

$\checkmark$ IRIS,

$\checkmark$ LADY IS-SLIPPER, RAM:S-LEAD

$\checkmark$ LADYIS-SLIPPER, SMALL KHITE

$\checkmark$ TWAYBLADE, AURICLEL

ORCHID. REIN-, SOUTHERN

$y$ GRASS, BLLE.

P PRIMROSE, BIRDIS-EYE

$7 T$ MONKSHODD, WILD, NORTHERN

$\checkmark$ SAXIFRAAGE, FORBE IS

SULLIVANTIA, KIDNEY-LEAVED

MYOTIS SODALIS

LYNX RUFUS

LYNX CANADENSIS

MARTES AMERI ICANA AMERICANA

LUTFA CANADENSIS

CANIS LUPUS

GRUS AMERICANA

NUMENIUS BOREAL IS

HAL IAEETUS LEUCOCEPHALUS

FALCO PEREGRINUS TUNDRIUS

ANIUS LUDOVICIANUS SSP.

DENDROICA KIRTLANDI I

THAMNOPHIS SIRTAL IS SEMIFASCIATA

CLONIOPHIS KIRTLANDII

COREGONUS ALPENAE

AMMOCRYPTA ASPRELLA

AMPSILIS HIGGINSI

STYGOBROMUS PUTEAL IS

LYCAEIDES MEL ISSA SAMUEL IS

CATOCALA MARMORATA

ARCYNOPTERYX COMPAC ${ }^{-} A$

PANAX QUINQUEFOL IUS

ASCLEPIAS MEADI I

GNAPHALIUM OBTUSIFOLIUM VAR, SAXICOLA

LESPEDEZA LEPTOSTACHYA

OXYTROPIS CAMPESTRIS VAR. CHARTACEA

IRIS LACUSTRIS

CYPRIPEDIUY ARIETINUM

CYPRIPEDIUM CANDIDUH

ISTERA AUR ICULATA

PLATANTHERA (HABENARIA) FLAVA

PLATANTHERA (HABENARIA) LEUCOPHAEA

POA PALUDIGENA

GYMNOCARP IUM HETEROSPORUM

INOODSIA ABBEAE

PRIMULA MISTASSINICA

ACONI TUM NOVEBORACENSE

HYDRAST IS CANADENSIS

SAXIFRAGA FORBESII

SULL IVANTIA RENIFOL IA

\begin{tabular}{ll} 
& \\
VESPERT IL IONIDAE & MAMMALS \\
FELIDAE & MAMMALS \\
FELIDAE & MAMMALS \\
MUSTELIDAE & MAMMALS \\
MUSTELIDAE & MAMMALS \\
CANIDAE & MAMMALS \\
GRUIDAE & BIRDS \\
SCOLOPACIDAE & BIRDS \\
ACCIPITRIDAE & BIRDS \\
FALCONIDAE & BIRDS \\
LANIIDAE & BIRDS \\
PARULIDAE & BIRDS \\
COLUBRIDAE & REPTILES \\
COLUBRIDAE & REPTILES \\
SALMONIDAE & FISH \\
PERCIDAE & FISH \\
UNIONIDAE & CLAMS \\
GAMMARIDAE & CRUSTACEAN \\
LYCAENIDAE & INSECTS \\
NOCTUIDAE & INSECTS \\
PERLODIDAE & INSECTS \\
ARALIACEAE & PLANTS \\
ASCLEPIADACEAE & PLANTS \\
ASTERACEAE (COMPOS PLANTS \\
ASTERACEAE ICOMPOS PLANTS \\
FABACEAE (LEGUMINO PLANTS \\
FABACEAE CLEGUMINO PLANTS \\
IRIDACEAE & PLANTS \\
ORCHIDACEAE & PLANTS \\
ORCHIDACEAE & PLANTS \\
ORCHIDACEAE & PLANTS \\
ORCHIDACEAE & PLANTS \\
ORCHIDACEAE & PLANTS \\
POACEAE (GRAMINEAE PLANTS \\
POLYPODIACEAE & PLANTS \\
POLYPODIACEAE & PLANTS \\
PRIMULACEAE & PLANTS \\
RANUNCULACEAE & PLANTS \\
RANUNCULACEAE & PLANTS \\
SAXIFRAGACEAE & PLANTS \\
SAXIFRAGACEAE & PLANTS \\
& \\
\hline &
\end{tabular}


SELECTION BY STATE STATUS MASK 1111111111 GROUP MASK 11111111111 (SEE OPTIONS PAGE ABOVE) RUN DATE O1/03/80 REGION 3 TWIN CITIES WISCONSIN

GROUP ENDANGER THREATEN BOTH E+T PROPOSED REVIEW DELISTED REJECTED CANDIDAT

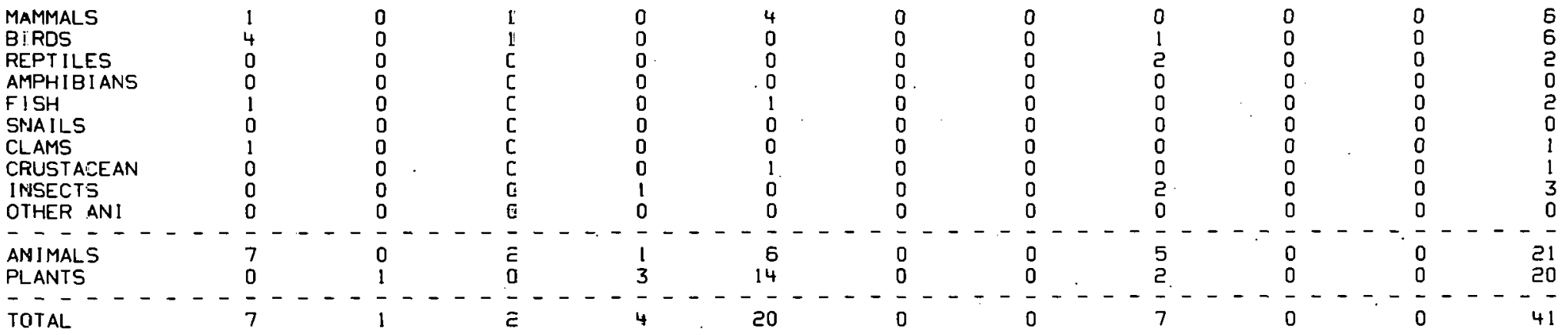

\section{BOXSCORE}




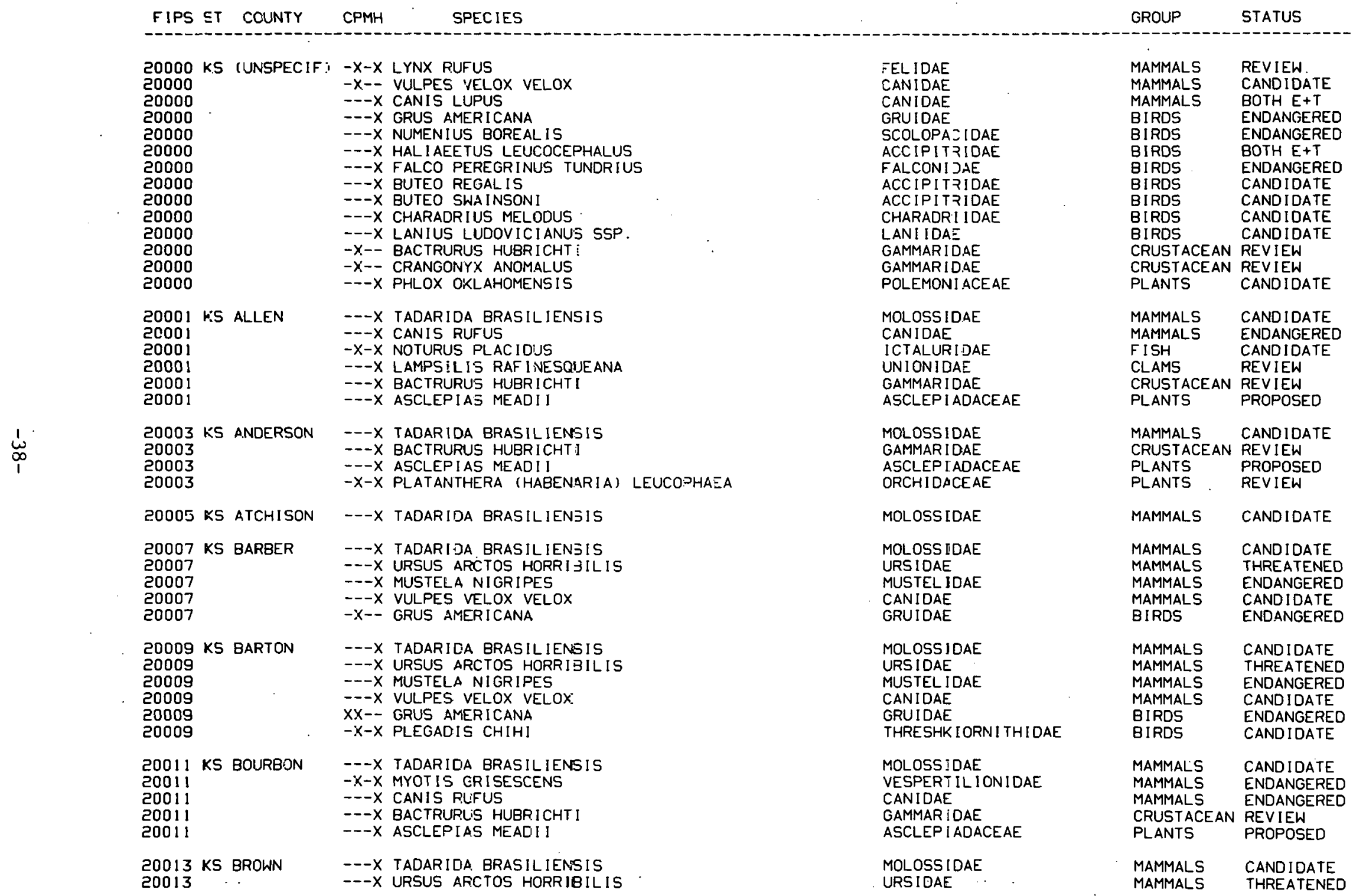


$1000 \mathrm{AL}$ (UNSPECIF)

$1001 \mathrm{AL}$ AUTAUGA

1003 AL BALDWIN

1005 AL BARBOUR

1007 AL BIBB

1009 AL BLOUNT

1011 AL BULLOCK

1013 AL .BUTLER

1015 AL CALHOUN

1017 AL CHAMBERS

1019 AL CHEROKEE

1021 AL CHILTON

1023 AL CHOCTAW

1025 AL CLARKE

1027 AL CLAY

1029 AL CLEBURNE

1031 AL COFFEE

$1033 \mathrm{AL}$ COLBERT

$1035 \mathrm{AL}$ CONECUH

1037 AL COOSA

1039 AL COVINGTON

1041 AL CRENSHAW

1043 AL CULLMAN

$1045 \mathrm{AL}$ DALE

$1047 \mathrm{AL}$ DALLAS

1049 AL DE KALB

1051 AL ELMORE

1053 AL ESCAMBIA

1055 AL ETOWAH

1057 AL FAYETTE

1059 AL FRANKL IN

$1061 \mathrm{Al}$ GENEVA

1063 AL GREENE

1065 AL HALE

1067 AL HENRY

1069 AL HOUSTON

1071 AL JACKSON

1073 AL JEFFERSON

1075 AL LAMAR

1077 AL LAUDERDALE

1079 AL LAWRENCE

$1081 \mathrm{AL}$ LEE

1083 AL LIMESTONE

1085 AL LOWNDES

1087 AL MACON

1089 AL MADISON

1091 AL MARENGO

1093 AL MARION

1095 AL MARSHALL

1097 AL MOBILE
1099 AL MONROE

1101 AL MONTGOMERY

1103 AL MORGAN

1105 AL PERRY

$1107 \mathrm{AL}$ PICKENS

1109 AL PIKE

1111 AL RANDOLPH

1113 AL RUSSELL

1115 AL ST CLAIR

$1117 \mathrm{AL}$ SHELBY

1119 AL SUMTEK

1121 AL TALLADEGA

1123 AL TALLAPOOSA

1125 AL TUSCALDOSA

1127 AL WALKER

1129 AL WASHINGTON

1131 AL WILCOX

1133 AL WINSTON

$1999 \mathrm{AL}$ (ALL)

2000 AK (UNSPECIF)

2010 AK ALEUTIAN I

2020 AK ANCHORAGE

2030 AK ANGOON

2040 AK BARROW

2050 AK BETHEL

2060 AK BRIS BA BO

2070 AK BRISTOL BA

2080 AK CORDOVA-MC

2090 AK FAIRBANKS

2100 AK HAINES

2110 AK JUNEAU

2120 AK KENAI-COOK

2130 AK KETCHIKAN

2140 AK KOBUK

2150 AK KOOIAK

2160 AK KUSKOKWIM

2170 AK MATANUSKA-

2180 AK NOME

2190 AK OUTER KETC

2200 AK PRINCE OF

2ट10 AK SEWARD

อ2อ0 AK SITKA

2230 AK SKAGWAY-YA

2240 AK SOUTIIEAST

2250 AK UPPER YUKO

2260 AK VALDE. T-CHI

ट270 AK WADE HAMPT

2280 AK WRANGELL-P

2290 AK YUKON-KOYU

2999 AK (ALL)
3000 AS AM. SAMOA

$3001^{\circ}$ AS MANUA

3003 AS ROSE/SAND

3005 AS TUTUILA

3009 AS OTHER AS

3999 AS (ALL)

4000 AZ (UNSPECIF)

4001 AZ APACHE

4003 AZ COCHISE

4005 AZ COCONINO

4007 AZ GILA

4009 AZ GRAHAM

4011 AZ GREENLEE

4013 AZ MARICOPA

4015 AZ MOHAVE

4017 AZ NAVAJO

4019 AZ PIMA

4021 AZ PINAL

4023 AZ SANTA CRUZ

4025 AZ YAVAPAI

4027 AZ YUMA

4999 AZ (ALL)

5000 AR (UNSPECIF)

5001 AR ARKANSAS

5003 AR ASHLEY

5005 AR BAXTER

5007 AR BENTON

5009 AR BOONE

5011 AR BRADLEY

5013 AR CALHOUN

5015 AR CARROLL

5017 AR CHICOT

5019 AR CLARK

5021 AR CLAY

5023 AR CLEBURNE

5กDS AR CLEVELAND

5027 AR COLUMBIA

5029 AR CONWAY

5031 AR CRAIGHEAD

5033 AR CRAWFORD

5035 AR CRITTENDEN

5037 AR CROSS

5039 AR DALLAS

5041 AR DESHA

5043 AR DREW

5045 AR FAULKNER

5047 AR FRANKL IN

5049 AR FULTON

5051 AR GARLAND

5053 AR GRANT 
5055 AR GREENE

5057 AR HEMPSTEAD

5059 AR HOT SPRING

5061 AR HOWARD

5063 AR INDEPENDEN

5065 AR IZARD

5067 AR - JACKSON

5069 AR JEFFERSON

5071 AR JOHNSON

5073 AR I AFAYETTE

5075 AR LAWRENCE

5077 AR LEE

$507 y$ AR I. INCOLN

5081 AR LITTLE RIV

5083 AR LOGAN

5085 AR LONOKE

5087 AR MADISON

5089 AR MARION

5091 AR MILLER

5093 AR MISSISSIPP

5095 AR MONROE

5097 AR MONTGOMERY

5099 AR NEVADA

5101 AR NEWTON

5103 AR OUACHITA

5105 AR PERRY

5107 AR PHILLIPS

5109 AR PIKE

5111 AR POINSETT

5113 AR POLK

5115 AR POPE

5117 AR PRAIRIE

5119 AR PULASKI

5121 AR RANDOLPH

5123 AR ST FRANCIS

5125 AR SAL INE

5127 AR SCOT1

SI G AR SEARC'

5131 AR SEBASTIAN

5133 AR SEVIER

5135 AR SHARP

5151 AR STONE

5139 AR UNION!

5141 AR VAN BUREN

5143 AR WASHINGTON

5145 AR WHITE

5147 AR WOODRUFF

5149 AR YELL

5999 AR (ALL)

6000 CA (UNSPECIF)
6001 CA ALAMEDA

6003 CA ALPINE

6005 CA AMADOR

6007 CA BUTTE

6009 CA CALAVERAS

6011 CA COLUSA

6013 CA CONTRA COS

6015 CA DEL NORTE

6017 CA EL DORADO

6019 CA FRESNO

6021 CA GLENN

6023 CA HUMBOLDT

6025 CA IMPERIAL

6027 CA INYO

6029 CA KERN

6031 CA KINGS

6033 CA LAKE

6035 CA LASSEN

6037 CA LOS ANGELE

6039 CA MADERA

6041 CA MARIN

6043 CA MARIPOSA

6045 CA MENDOC INO

6047 CA MERCED

6049 CA MODOC

6051 CA MONO

6053 CA MONTEREY

6055 CA NAPA

6057 CA NEVADA

6059 CA DRANGE

G0IG1 CA PLACER

6063 CA PLUMAS

6065 CA RIVERSIDE

6067 CA SACRAMENTO

6069 CA SAN BENITO

6071 CA SAN BERNAR

6073 CA SAN DIEGO

6075 CA SAN TRANCI

6077 CA SAN JOAQUI

6079 CA SAN LUIS O

6081 CA SAN MATEO

6083 CA SANTA BARB

6085 CA SANTA CLAR

$608 \%$ CA SANTA CRUZ

6089 CA SHASTA

6091 CA SIERRA

6093 CA SISKIYOU

6095 CA SOLANO

6097 CA SONOMA

6099 CA STANISLAUS
6101 CA SUTTER

6103 CA TEHAMA

6105 CA TRINITY

6107 .CA TULARE

6109 CA TUOLUMNE

6111 CA VENTURA

6113 CA YOLO

$6115 \mathrm{CA}$ YUBA

$6201 \mathrm{CA}$ ANACAPA IS

6203 CA SAN CLEM I

GL05 CA SAN MIGUI I

6207 CA SAN NICO I

6209 CA STA BARB I

E211 CA STA CATA I

6213 CA STA CRUZ I

6215 CA STA ROSA I

6999 CA (ALL)

7000 CZ CANAL ZONE

$7999 \mathrm{CZ}$ (ALL)

8000 CO (UNSPECIF)

8001 CO ADAMS

8003 CO ALAMOSA

8005 CO ARAPAHOE

8007 CO ARCHULETA

8009 CO BACA

8011 CO BENT

8013 CO BOULDER

8015 CO CHAFFEE

8017 CO CHEYENNE

8019 CO CLEAR CREE

8021 CO CONE.JUS

8023 CO COST ILLA

8025 CO CROWLEY

8027 CO CUSTER

8029 CO DELTA

8031 CO DENVER

8033 CO DOLORES

8035 CO DOUGL_AS

8037 CO EAGLE

8039 CO ELBERT

8041 CO EL PASO

8043 CO FREMONT

8045 CO GARF IELD

8047 LO GILPIN

8049 CO GRAND

8051 CO GUNNISON

8053 CO HINSDALE

8055 CU HUERFANO

8057 CO JAC.KSON

8059 CO JEFFERSON 
8061 CO KIOWA

8063 CO KIT CARSON

8065 CO LAKE

8067 CO LA PLATA

8069 CO LARIMER

8071 CO LAS ANIMAS

8073 CO LINCOLN

8075 CO LOGAN

8077 CO MESA

8079 CO MINERAL

8081 CO MOFFAT

8083 CO MONTEZUMA

8085 CO MONTROSE

8087 CO MORGAN

8089 CO OTERO

8091 CO OURAY

8093 CO PARK

8095 CO PHILLIPS

8097 CO PITKIN

8099 CO PROWERS

8101 CO PUEBLO

8103 CO RIO BLANCO

8105 CO RIO GRANDE

8107 CO ROUTT

8109 .0 SAGUACHE

8111 CO SAN JUAN

8113 CO SAN MIGUEL

8115 CO SEDGWICK

8117 CO SUMMIT

8119 CO TELLER

8121 CO WASHINGTON

8123 CO WELD

8125 CO YUMA

$8999 \mathrm{CO}$ (ALL)

9000 CT (UNSPECIF)

9001 CT FAIRF IELD

9003 CT HARTFORD

9005 CT LITCHF IELD

9007 CT MIDDLESEX

9009 CT NEW HAVEN

9011 CT NEW LONDON

9013 CT TOLLAND

9015 CT WINOHAM

9999 CT (ALL)

10000 DE (UNSPECIF)

10001 DE KENT

10003 DE NEW CASTLE

10005 DE SUSSEX

10999 DE (ALL)

11000 DC (UNSPECIF)
11001 DC DIST. COL.

11999 DC (ALL)

$12000 \mathrm{FL}$ (UNSPECIF)

$12001 \mathrm{FL}$ ALACHUA

$12003 \mathrm{FL}$ BAKER

$12005 \mathrm{FL}$ BAY

$12007 \mathrm{FL}$ BRADFORD

$12009 \mathrm{FL}$ BREVARD

$12011 \mathrm{FL}$ BROWARD

$12013 \mathrm{FL}$ CALHOUN

1 PO15 FL CHARLOTTE

$12017 \mathrm{FL}$ CITRUS

$12019 \mathrm{FL}$ CLAY

12021 FL COLLIER

$12023 \mathrm{FL}$ COLUMBIA

$12025 \mathrm{FL}$ DADE

12027 FL DE SOTO

$12029 \mathrm{FL}$ DIXIE

$12031 \mathrm{FL}$ DUVAL

$12033 \mathrm{FL}$ ESCAMBIA

12035 rL FLAGLER

$12037 \mathrm{FL}$ FRANKL IN

$12039 \mathrm{FL}$ GADSDEN

$12041 \mathrm{FL}$ GILCHRIST

$12043 \mathrm{FL}$ GLADES

$12045 \mathrm{FL}$ GULF

$12047 \mathrm{FL}$ HAMILTON

$12049 \mathrm{FI}$. HARDEE

$12051 \mathrm{FL}$ HENDRY

$12053 \mathrm{FL}$ HERNANDO

$12055 \mathrm{FL}$ HIGHLANDS

$12057 \mathrm{FL}$ HILLSBOROU

$12059 \mathrm{FL}$ HOLMES

$12061 \mathrm{FL}$ INDIAN RIV

$12063 \mathrm{FL}$ JACKSON

$12065 \mathrm{FL}$ JEFFERSON

$12067 \mathrm{FL}$ LAFAYETTE

$12069 \mathrm{FL}$ LAKE

12071 FL LEE

$12073 \mathrm{FL}$ LEON

$12075 \mathrm{FL}$ LEVY

12077 FL LIBERTY

12079 FL MADISON

$12081 \mathrm{FL}$ MANATEE

$12083 \mathrm{FL}$ MARION

$12085 \mathrm{FL}$ MARTIN

$12087 \mathrm{FL}$ MONROE

$12089 \mathrm{FL}$ NASSAU

$12091 \mathrm{FL}$ OKALOOSA

$12093 \mathrm{FL}$ OKEECHOBEE
$12095 \mathrm{FL}$ ORANGE

$12097 \mathrm{FL}$ OSCEOLA

$12099 \mathrm{FL}$ PALM BEACH

$12101 \mathrm{FL}$ PASCO

12103 FL PINELLAS

12105 FL POLK

$12107 \mathrm{FL}$ PUTNAM

$12109 \mathrm{FL}$ ST JOHNS

$12111 \mathrm{FL}$ ST LUCIE

$12113 \mathrm{FL}$ SANTA ROSA

$12115 \mathrm{FL}$ SARASOTA

$12117 \mathrm{FL}$ SEMINOLE

$12119 \mathrm{FL}$ SUMTER

$12121 \mathrm{FL}$ SUWANNEE

$12123 \mathrm{FL}$ TAYLOR

$12125 \mathrm{FL}$ UNION

$12127 \mathrm{FL}$ VOLUSIA

$12129 \mathrm{FL}$ WAKULLA

$12131 \mathrm{FL}$ WALTON

$12133 \mathrm{FL}$ WASHINGTON

12201 FL KEYS (IS.)

$12999 \mathrm{FL}$ (ALL)

13000 GA (UNSPECIF)

13001 GA APPLING

13003 GA ATKINSON

13005 GA BACON

13007 GA BAKER

13009 GA BALDWIN

13011 GA BANKS

13013 GA BARROW

13015 GA BARTOW

13017 GA BEN HILL

13019 GA BERRIEN

13021 GA BIBB

13023 GA BLECKLEY

130 . 5 GA RRANTLEY

13027 GA BROOKS

13029 GA BRYAN

13031 GA BULLOCH

13033 GA BURKE

13035 GA BUTTS

13037 GA CALHOUN

13039 GA CAMDEN

13043 GA CANDLER

13045 GA CARROLL

13047 GA CATOOSA

13049 GA CHARLTON

13051 GA CHATHAM

13053 GA CHATTAHOOC

13055 GA CHATIOOGA 
13057 GA. CHEROKEE 13059 GA CLARKE 13061 GA CLAY 13063 GA CLAYTON 13065 GA CL INCH 13067 GA COBB 13069 GA COFFEE 13071 GA COLQUITT 13073 GA COLUMBIA $13 U / \zeta$ GA LUÜK 13077 GA COWETA 13079 GA CRAWFORD 13081 GA CRISP 13083 GA DADE 13085 GA DAWSON 13087 GA DECATUR 13089 GA DE KALB 13091 GA DODGE 13093 GA DOOLY 13095 GA DOUGHERTY 13097 GA DOUGLAS 13099 GA EARI..Y 13101 GA ECHOLS 13103 GA EFF INGHAM 13105 GA ELBERT 13107 GA EMANUEL 13109 GA EVANS 13111 GA FANNIN 13113 GA FAYETTE 13115 GA FLOYD 13117 GA FORSYTH 13119 GA FRANKL IN 13121 GA FULTON 13123 GA GIILMER 13125 GA GLASCOCK 13127 GA GLYNN 13129 GA GORDON 13131 GA GRADY 13133 GA GREENF 13135 GA GWINNETT 13137 IAA HARERSHAM 13139 GA HALL 13141 GA HANCOCK 13143 GA HARALSON 13145 GA HARRIS 13147 GA HART 13149 GA HEARD 13151 GA HIENRY 13153 GA HOUSTON 13155 GA IRWIN
13157 GA JACKSON 13159 GA JASPER 13161 GA JEFF DAVIS 13163 GA JEFFERSON 13165 GA JENKINS 13167 GA JOHNSON 13169 GA JONES 13171 GA LAMAR 13173 GA LANIER 13175 CA LAURENS 13177 GA LEE 13179 GA LIBERTY 13181 CA LINCOLN 13183 GA LONG 13185 GA LOWNDES 13187 GA LUMPKIN 13189 GA MC DUFFIE 1319.1 GA MC INTOSH 13193 GA MACON 13195 GA MADISON 13197 GA MARION 13199 GA MERIWETHER 13201 GA MILLER 13205 GA MITCHELL 13207 GA MONROE 13209 GA MONTGOMERY 132 I 1 GA IORGAN 13213 GA MURRAY 13215 GA MUSCOGEE 132.17 GA NEWTON 13219 GA OCONEE I उ己ट) GA OGLETHORPE 13223 GA PAULDING 13225 GA PEACH 13227 GA PICKENS 132 GS GA PIERCE 13231 GA PIKE 13233 GA POLK 13235 GA PULASK. I 13237 GA PUTNAM 13239 GA QUITMAN 13241 GA RABUN 1 곤. 3 GA RANDOLPH 13245 GA RICHMOND 13247 GA ROCKDALE 13249 GA SCHLEY 13251 GA SCREVEN 13253 GA SFMINOLE 13255 GA SPALDING 13257 GA STEPHENS
13259 GA STEWART

13261 GA SUMTER

13263 GA TALBOT

13265 GA TAL I AFERRO

13267 GA TATTNALL

13269 GA TAYLOR

13271 GA TELFAIR

13273 GA TERRELL

13275 GA THOMAS

13277 GA TIFT

13279 GA TOOMBS

13281 GA TOWNS

13283 GA TREUTLEN

13285 GA TROUP

13287 GA TURNER

13289 GA TWIGGS

13291 GA UNION

13293 GA UPSON

13295 GA WALKER

13297 GA WALTON

13299 GA WARE

13301 GA WARREN

13303 GA WASHINGTON

13305 GA WAYNE

13307 GA WEBSTER

13309 GA WHEELER

13311 GA 1.HHITE

13313 GA WHITF IELD

13315 GA WILCOX

13317 GA WILK'ES

13319 GA WILKINSON

133 I 1 GA WORTH

13999 GA (ALL)

14000 GU GUAM

14999 GU (ALL)

$15000 \mathrm{HI}$ (UNSPECIF)

$15001 \mathrm{HI}$ HAWAII

15003 HI HONOLULU

$15007 \mathrm{HI}$ KAUAI

$15009 \mathrm{HI}$ MAUI

$15011 \mathrm{HI}$ HAWAII I. $15 U 13$ HI KAHOOLAWE. 15015 IIT KAIJAI I. $15017 \mathrm{HI}$ KAULA I. $15018 \mathrm{HI}$ KURE I . $15019 \mathrm{HI}$ LANAI I . $15020 \mathrm{HI}$ LAYSAN I. $15021 \mathrm{HI}$ LEEWARD IS $15022 \mathrm{HI}$ LISIANSKI. 15023 HI MAUI I. 


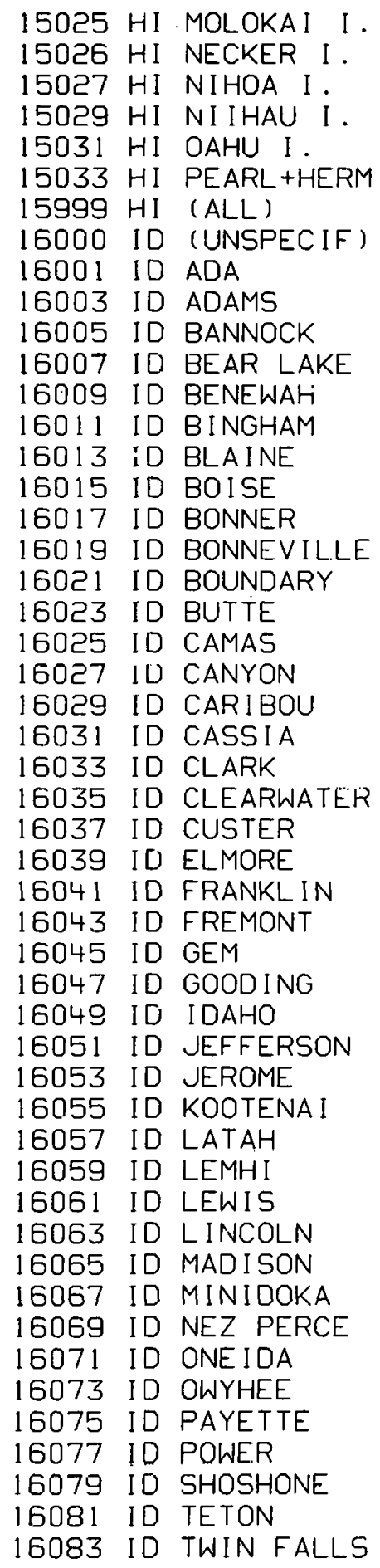

16085 ID VALLEY

16087 ID WASHINGTON

16999 ID (ALL)

17000 IL (UNSPECIF)

17001 IL ADAMS

17003 IL ALEXANDER

17005 IL BOND

17007 IL BOONE

17009 IL BROWN

17011 IL BUREAU

17013 IL CALHOIN

17015 IL CARROLL

17017 IL CASS

17019 IL CHAMPAIGN

17021 IL CHRISTIAN

17023 IL CLARK

17025 IL CLAY

17027 IL CLINTON

17029 IL COLES

17031 IL COOK

17033 IL CRAWFORD

17035 IL CUMBERLANO

17037 IL DE KALB

17039 IL DE WITT

17041 IL DOUGLAS

17043 IL DU PAGE

17045 IL EDGAR

17047. IL EDWARDS

17049 IL EFF INGHAM

17051 IL FAYETTE

17053 IL FORD

17055 IL FRANKL IN

17057 IL FULTON

17059 IL GALLATIN

17061 IL GREENE

17063 IL GRUNDY

1.7065 IL HAMILTON

17067 IL HANCOCK

17069 IL HARDIN

17071 IL HENDERSON

17073 IL HENRY

17075 IL IROQUOIS

I 7077 IL JACKSON

17079 IL JASPER

17081 IL JEFFERSON

17083 IL JERSEY

17085 IL JO DAVIESS

17087 IL JOHNSON

17089 IL KANE

17091 IL KANKAKEE
17093 IL KENDALL

17095 IL KNOX

17097 IL LAKE

17099 IL LA SALLE

17101 IL LAWRENCE

17103 IL LEE

17105 IL LIVINGSTON

17107 IL LOGAN

17109 IL MC DONOUGH

17111 IL MC HENRY

17113 IL MC LEAN

17115 IL MACON

17117 IL MACOUPIN

17119 IL MADISON

17121 IL MARION

17123 IL MARSHALL

17125 IL MASON

17127 IL MASSAC

17129 IL MENARD

17131 IL MERCER

17133 IL MONROE

17135 IL MONTGOMERY

17137 IL MORGAN

17139 IL MOULTRIE

17141 IL OGLE

17143 IL PEORIA

17145 IL PERRY

17147 IL PIATT

17149 IL PIKE

17151 IL POPE

17153 IL PULASKI

17155 IL PUTNAM

17157 IL RANDOLPH

17159 IL RICHLAND

17161 IL ROCK ISLAN

17163 IL ST CLAIR

17165 IL SAL INE

17167 IL SANGAMON

17169 IL SCHUYLER

17171 IL SCOTT

17173 IL SHELBY

17175 IL... STARK

17177 IL STEPHENSON

17179 IL TAZEWELL

17181 IL UNION

17183 IL VERMILION

17185 IL WABASH

17187 IL WARREN

17189 IL WASHINGTON

17191 IL WAYNE 


\begin{tabular}{|c|c|c|}
\hline 7193 & IL & \\
\hline 17195 & IL & WHITESIDE \\
\hline 17197 & IL & WILL \\
\hline 17199 & IL & WILL I AMSON \\
\hline 17201 & IL & WINNEBAGO \\
\hline 17203 & IL & WOODF ORD \\
\hline 17999 & IL & (ALL) \\
\hline 18000 & IN & (UNSPEC IF) \\
\hline 18001 & IN & ADAMS \\
\hline 10003 & IN & ᄉLLEEN \\
\hline 18005 & IN & BARTHOLOME \\
\hline 18007 & IN & BENTON \\
\hline 18009 & IN & BLACKFORD \\
\hline 18011 & IN & BOONE \\
\hline 18013 & IN & BROWN \\
\hline 18015 & IN & CARROLL \\
\hline 18017 & IN & CASS \\
\hline 18019 & IN & CLARK \\
\hline 18021 & IN & CLAY \\
\hline 18023 & IN & CLINTON \\
\hline 18025 & IN & CRAWFORD \\
\hline 18027 & IN & DAVIESS \\
\hline 18029 & IN & DEAFBORN \\
\hline 180.31 & IN & DECATUR \\
\hline 18033 & IN & DE KALB \\
\hline 18035 & IN & DELAWARE \\
\hline 18037 & IN & DUBO I S \\
\hline 18039 & IN & ELKHART \\
\hline 18041 & IN & FAYETTE \\
\hline 18043 & IN & FI_OYD \\
\hline 18045 & IN & FOUNTAIN \\
\hline 18047 & IN & FRANKL I N \\
\hline 18049 & IN & FULTON \\
\hline 18051 & IN & GIBSON \\
\hline 18053 & IN & GRAN I \\
\hline 18055 & IN & GREENE \\
\hline $18 \cap 57$ & IN & HAMILTON \\
\hline 18059 & IN & HANCOCK \\
\hline 18061 & IN & HARR I SON \\
\hline 18063 & IN & HENDR I CKS \\
\hline & IN & HENRY \\
\hline 18067 & IN & HOWAKU \\
\hline 18069 & IN & HIINT INCTON \\
\hline 18071 & IN & JACKSON \\
\hline 18073 & IN & JASPER \\
\hline 18075 & IN & JA.Y \\
\hline & IN & JEFFERSON \\
\hline & IN & JENNINGS \\
\hline & IN & JOHNSON \\
\hline & In & \\
\hline
\end{tabular}

\begin{tabular}{|c|c|c|c|c|}
\hline 18085 & KOSC IUSKO & 18999 & IN & $(A L L)$ \\
\hline 18087 & LAGRANGE & 19000 & I A & (UNSPEC.IF) \\
\hline 18089 & LAKE & 19001 & I A & ADA IR \\
\hline 18091 & IN LA PORTE & 19003 & I A & ADAMS \\
\hline 18093 & LAWRENCE & 19005 & I A & ALLAMAKEE \\
\hline 18095 & MAD I SON & 19007 & I A & APPANOOSE \\
\hline 18097 & MARION & 19009 & IA & AUDUBON \\
\hline 18099. & MARSHALL & 19011 & I A & BENTON \\
\hline 18101 & MART I N & 19013 & I A & BLACK HAWK \\
\hline 18103 & MIAMI & 19015 & I A & BOONE \\
\hline 18105 & MONROE & $1 \cup \cup 17$ & I A & BREFIER \\
\hline 18107 & MONTGOMERY & 19019 & I A & BUCHANAN \\
\hline 18109 & IN MORGAN & 19021 & I A & BUENA, VIST \\
\hline 18111 & IN NEWTON & 19023 & I A & BUTLER \\
\hline 18113 & NOBLE & 19025 & I A & CALHOUN \\
\hline 18115 & IN OHIO & 19027 & I A & CARROLL \\
\hline 18117 & IN ORANGE & 19029 & I A & CASS \\
\hline 18119 & OWEN & 19031 & I A & CEDAR \\
\hline 18121 & IN PARKE & 19033 & I A & CERRO GORD \\
\hline 18123 & IN PERRY & 19035 & I A & CHEROKEE \\
\hline 18125 & PIKE & 19037 & IA & CHICKASAW \\
\hline 18127 & PORTER & 19039 & I A & CLARKE \\
\hline 18129 & POSEY & 19041 & I A & CLAY \\
\hline 18131 & PULASK I & 19043 & I A & CLAYTON \\
\hline 18133 & FUTNAM & 19045 & I $\mathrm{A}$ & CL INTON \\
\hline 18135 & RANDOI_PH & 19047 & I A & CRAWF ORD \\
\hline 18137 & RIPLEY & 19049 & I A & DALLAS \\
\hline 18139 & RUSH & 19051 & I A & DAVIS \\
\hline 18141 & ST JOSEPH & 19053 & I A & DECATUR \\
\hline 18143 & SCOTT & 19055 & IA & DELAWARE \\
\hline 18145 & SHHLEY & 19057 & I A & DES MOINES \\
\hline 18147 & SPFNC.FR & 19059 & I A & DICKINSON \\
\hline 18149 & STARKE & 19061 & I A & DUBUQUE \\
\hline 18151 & STEUBEN & 19063 & I A & EMMET \\
\hline 18153 & SULL IVAN & 19065 & I A & FAYETTE \\
\hline 18155 & SW I T:ZERLAN & 19067 & I A & FLOYO \\
\hline 18157 & TIPPECANOE & 19069 & I $A$ & FRANKLIN \\
\hline 18159 & I IF'TUNN & 19071 & I A & FRFMONT \\
\hline 18 & IN UNION & $190 \% 3$ & I A & GREENE \\
\hline 18163 & VANDERBURG & 15075 & I A & GRUNDY \\
\hline 65 & VERMILLION & 19077 & I A & GUTHR IE \\
\hline 18197 & VI CO & 19079 & I $A$ & HAMII.. TON \\
\hline 18169 & WARASH & 19081 & I A & HANCOCK \\
\hline 171 & WARREN & 1 पบU४ं & I A & HARDIN \\
\hline 18173 & WARR I CK & 19085 & I $A$ & HARR I SON \\
\hline 175 & WASHINGTON & 19087 & IA & HENRY \\
\hline 18177 & IN WAYNE & 19089 & I A & HOWARD \\
\hline 18179 & WELLS & 19091 & I A & HIUMBOLDT \\
\hline & WHITE & 19093 & I A & IDA \\
\hline 18183 & WH I TLEY & 19095 & I A & I OWA \\
\hline
\end{tabular}


19097 IA JACKSON

19099 I A JASPER

19101 I A JEFFERSON

19103 I A JOHNSON

19105 I A JONES

19107 I A KEOKUK

19109 IA KOSSUTH

19111 IA LEE

19113 IA LINN

19115 IA LOUISA

$1911 \%$ IA LUCAS

$19119 \cdot$ IA LYON

19121 IA MADISON

19123 I A MAHASKA

19125 I A MARION

19127 IA MARSHALL

19129 IA MILLS

19131 IA MITCHELL

19133 IA MONONA

19135 I A MONROE

19137 I A MONTGOMERY

19139 I A MUSC.ATINE

19141 IA O\#BFIEN

19143 I A OSCEOLA

19145 IA PAGE

19147 IA PALO ALTO

19149 IA PLYMOUTH

19151 IA POCAHONTAS

19153 IA POLK

19155 I A POTTAWATTA

19157 I A POWESHIEK

19159 IA RINGGOLD

19161 IA SAC

19163 IA SCOTT

19165 IA SHELBY

19167 IA SIOUX

19169 IA STORY

19171 IA TAMA

19173 IA TAYLOR

19175 IA UNION

19177 I A VAN BUREN

19179 I A. WAPELLO

19181 I A WARREN

13183 IA WASHIINGTON

19185 IA WAYNE

1.9187 I A WEBSTER

19189 IA WINNEBAGO

19191 IA WINNESHIEK

19193 I A WOODBURY

19195 IA WORTH
19197 I A WRIGHT

19999 I A (ALL)

$20000 \mathrm{KS}$ (UNSPECIF)

$20001 \mathrm{KS}$ ALLEN

$20003 \mathrm{KS}$ ANDERSON

$20005 \mathrm{KS}$ ATCHISON

$20007 \mathrm{KS}$ BARBER

20009 KS BARTON

$20011 \mathrm{KS}$ BOURBON

$20013 \mathrm{KS}$ BROWN

$20015 \mathrm{KS}$ BUTLER

$20017 \mathrm{KS}$ CHASE

20019 KS CHAUTAUQUA

20021 KS CHEROKEE

$20023 \mathrm{KS}$ CHEYENNE

$20025 \mathrm{KS}$ CLARK

$20027 \mathrm{KS}$ CLAY

20029 KS CLOUD

20031 KS COFFEY

$20033 \mathrm{KS}$ COMANCHE

$20035 \mathrm{KS}$ COWLEY

$20037 \mathrm{KS}$ CRAWFORD

$20039 \mathrm{KS}$ DECATUR

$20041 \mathrm{KS}$ DICKINSON

$20043 \mathrm{KS}$ DONIPHAN

$20045 \mathrm{KS}$ DOUGLAS

$20047 \mathrm{KS}$ EDWARDS

20049 KS ELK

$20051 \mathrm{KS}$ ELLIS

$20053 \mathrm{KS}$ ELLSWORTH

$20055 \mathrm{KS}$ FINNEY

20057 KS. FORD

20059 KS FRANKL IN

$20061 \mathrm{KS}$ GEARY

$20063 \mathrm{KS}$ GOVE

20065 KS GRAHAM

$20067 \mathrm{KS}$ GRANT

20069 KS GRAY

$20071 \mathrm{KS}$ GREELEY 20073 KS GREENWOOD

$20075 \mathrm{KS}$ HAMILTON

$20077 \mathrm{KS}$ HARPER

$20079 \mathrm{KS}$ HARVEY

20001 KS WASKELL

$20083 \mathrm{KS}$ HODGEMAN

$20085 \mathrm{KS}$ JACKSON

$20087 \mathrm{KS}$ JEFFERSON

$20089 \mathrm{KS}$ JEWELL

20091 KS JOHNSON

20093 KS KEARNY
20095 KS KINGMAN

20097 KS KIOWA

20099 KS LABETTE

$20101 \mathrm{KS}$ LANE

20103 KS LEAVENWORT

20105 KS LINCOLN

20107 KS LINN

20109 KS LOGAN

20111 KS LYON

$20113 \mathrm{KS}$ MC PHERSON

20115 KS MARION

20117 KS MARSHALL

$20119 \mathrm{KS}$ MEADE

20121 KS MIAMI

20123 KS MITCHELL

20125 KS MONTGOMERY

20127 KS MORRIS

20129 KS MORTON

20131 KS NEMAHA

20133 KS NEOSHO

$20135 \mathrm{KS}$ NESS

20137 KS NORTON

20139 KS OSAGE

20141 KS OSBORNE

$20143 \mathrm{KS}$ OTTAWA

20145 KS PAWNEE

20147 KS PHILLIPS

20149 KS POTTAWATOM

20151 KS PRATT

20153 KS RAWL INS

20155 KS RENO

20157 KS REPUBL IC

20159 KS RICE

20161 KS RILEY

20163 KS ROOKS

20165 KS RIISH

20167 KS RUSSELL

20169 KS SALINE

20171 KS SCOTT

20173 KS SEDGWICK

$20175 \mathrm{KS}$ SEWARD

$20177 \mathrm{KS}$ SHAWNEE

20179 KS SHERIDAN

$20181 \mathrm{KS}$ SHERMAN

20183 KS SMITH

20185 KS STAFFORD

$20187 \mathrm{KS}$ STANTON

20189 KS STEVENS

$20191 \mathrm{KS}$ SUMNER

$20193 \mathrm{KS}$ THOMAS 


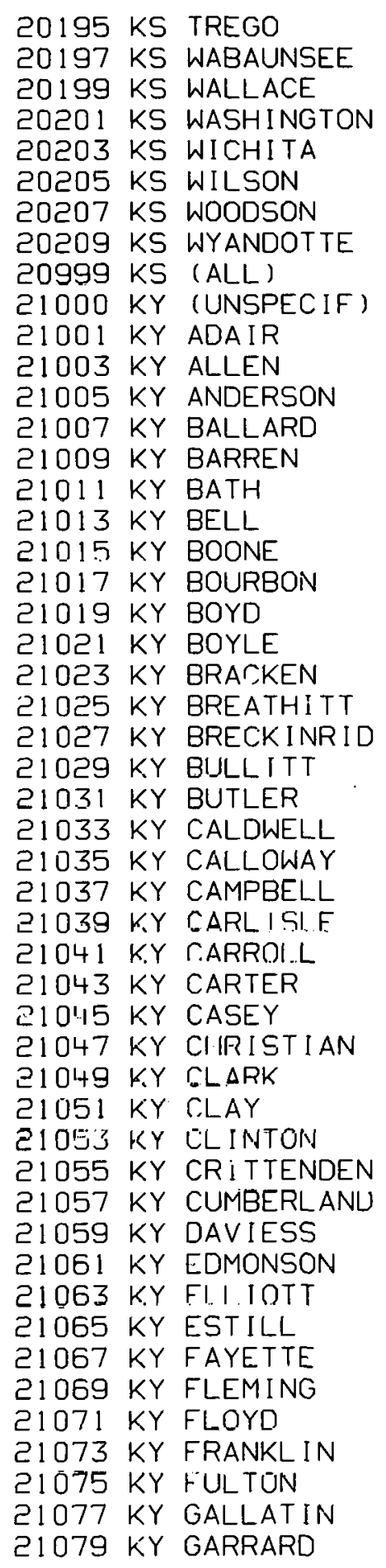

$21081 \mathrm{KY}$ GRANT

$21083 \mathrm{KY}$ GRAVES

21085 KY GRAYSON

$21087 \mathrm{KY}$ GREEN

$21089 \mathrm{KY}$ GREENUP

$21091 \mathrm{KY}$ HANCOCK

$21093 \mathrm{KY}$ HARDIN

$21095 \mathrm{KY}$ HARLAN

$21097 \mathrm{KY}$ HARR ISON

टlUYG KY HART

$21101 \mathrm{KY}$ HENDERSON

$21103 \mathrm{KY}$ HENRY

$21105 \mathrm{KY}$ HICKMAN

$21107 \mathrm{KY}$ HOPKINS

21109 KY JACKSON

$21111 \mathrm{KY}$ JEFFERSON

$21113 \mathrm{KY}$ JESSAMINE.

$21115 . K Y$ JOHNSON

$21117 \mathrm{KY}$ KENTON

$21119 \mathrm{KY}$ KNOTT

$21121 \mathrm{KY}$ KNOX

$21123 \mathrm{KY}$ LARUE

$21125 \mathrm{KY}$ LAUREL

$21127 \mathrm{KY}$ LAWRENCE

$21129 \mathrm{KY}$ LEE

21131 KY LESLIE

$21133 \mathrm{KY}$ LEICHER

$21135 \mathrm{KY}$ LEWIS

$211.37 \mathrm{KY}$ LINCOLN

211 $139 \mathrm{KY}$ LIVINGSTON

$21141 \mathrm{KY}$ LOGAN

$21143 \mathrm{KY}$ LYON

$21145 \mathrm{KY}$ MC CRACKEN

$21147 \mathrm{KY}$ MC CREARY

$21149 \mathrm{KY}$ MC LEAN

21151 KY MADISON

? $115.7 \mathrm{KY}$ MAGOFF IN

टl $155 \mathrm{KY}$ MARION

$21157 \mathrm{~K}^{\prime} Y$ MARSHALL

$21159 \mathrm{KY}$ MARTIN

$21161 \mathrm{KY}$ MASON

$21163 \mathrm{KY}$ MEADE

EI165 k'r MENIFEE

$21167 \mathrm{KY}$ MERCER

$21169 \mathrm{KY}$ METCALFE

$21171 \mathrm{KY}$ MONROE

$21173 \mathrm{KY}$ MONTGOMERY

21175 KY MORGAN

$21177 \mathrm{KY}$ MUHLENBERG

$21179 \mathrm{KY}$ NELSON
$21181 \mathrm{KY}$ NICHOLAS

$21183 \mathrm{KY}$ OHIO

$21185 \mathrm{KY}$ OLDHAM

$21187 \mathrm{KY}$ OWEN

21189 KY OWSLEY

21191 KY PENDLETON

$21193 \mathrm{KY}$ PERRY

21195 KY PIKE

21197 KY POWELL

21100 KY PULASK.I

$21201 \mathrm{KY}$ ROBERTSON

21203 KY ROCKCASTLE

$21205 \mathrm{KY}$ ROWAN

21207 KY RUSSELL

21209 KY SCOTT

$21211 \mathrm{KY}$ SHELBY

21213 KY SIMPSON

21215 KY SPENCER

$21217 \mathrm{KY}$ TAYLOR

21219 KY TODD

$21221 \mathrm{KY}$ TRIGG

21223 KY TRIMBLE

21225 KY UNION

$21227 \mathrm{KY}$ WARREN

21229 KY WASHINGTON

$21231 \mathrm{KY}$ WAYNE

21233 KY WEBSTER

21235 KY WHITLEY

$21237 \mathrm{KY}$ WOLFE

$21239 \mathrm{KY}$ WOODF URD

ट1999 KY (ALL)

¿2000 LA (UPSPPECIF)

22001 LA ACADIA

22003 LA ALLEN

22005 LA ASCENSION

¿¿U07 LA ASSUIMTIPT ION

P?RกB I.A AVOYELLES

22011 LA BEAUREGAKL

22013 LA BIENVILLE

22015 LA BOSSIER

22017 LA CADDO

22019 LA CALCASIEU

리리 LA CALONELL

22023 LA CAMERON

22025 LA CATAHOULA

22027 LA CLAIBORNE.

22029 LA CONCORDIA

22031 I.A DF. SOTO

22033 LA EAST BATON

22035 LA EAST CARRO 
22037 LA EAST FELIC 22039 LA EVANGEL INE 22041 LA FRANKLIN 22043 LA GRANT 22045 LA IBERIA 22047 LA IBERV ILLE 22049 LA JACKSON 22051 LA JEFFERSON 22053 LA JEFF. DAVIS 22055 LA LAFAYETTE 22057 LA LAFOURCHE 22059 LA LA SALLE 22061 LA LINCOLN 22063 LA LIVINGSTON 22065 LA MADISON 22067 LA MOREHOUSE 22069 LA NATCHITOCH 22071 LA ORLEANS 22073 LA OUACHITA 22075 LA PLAQUEMINE 2?077 LA POINTE COU 22079 LA RAPIDES 22081 LA RED RIVER 22083 LA RICHLAND 22085 LA SABINE 22087 LA ST BERNARD 22089 LA ST CHARLES 22091 LA ST HELENA 22093 LA ST JAMES 22095 LA ST JOHN TH 22097 LA ST LANDRY 22099 LA ST MARTIN 22101 LA ST MARY 22103 LA ST TAMMANY 22 105 LA TANGIPAHOA 22107 LA TENSAS 2己100 LA TLRRLDONNNE 22111 LA UNION 22113 LA VERMILION 22115 LA VERNON 22117 LA WASHINGTON 22119 LA WEBSTER 22121 LA WEST BATON 22123 LA WEST CARRO 22125 LA WEST FELIC 22127 LA WINN T.P999 LA (ALL) $23000 \mathrm{ME}$ (UNSPECIF) .23001 ME ANOKUSCOGG 23003 ME AROOSTOOK
23005 ME CUMBERLAND 23007 ME FRANKL IN 23009 ME HANCOCK 23011 ME KENNEBEC 23013 ME KNOX 23015 ME LINCOLN 23017 ME OXFORD 23019 ME PENOBSCOT 23021 ME PISCATAQUI 23023 ME SAGADAHOC 23025 ME SOMERSET 23027 ME WALDO 23029 ME WASHINGTON 23031 ME YORK 23999 ME (ALL) 24000 MD (UNSPECIF) 24001 MD ALLEGANY 24003 MD ANNE ARUND 24005 MD BALTIMORE 24009 MD CALVERT 24011 MD CAROL INE 24013 MD CARROLL 24015 MD CECIL 24017 MD CHARLES 24019 MD DORCHESTER 24021 MD FREDERICK 24023 MD GARRETT 24025 MD HARFORD 24027 MD HOWARD 24029 MD KENT 24031 MD MONTGOMERY 24033 MD PRINCE GEO 24035 MD QUEEN ANNE 24037 MD ST MARYS 24039 MD SOMERSET 24041 MD TALBOT .24043 1\%D WASHINGTUN 24045 MD WICOMICO 24047 MD WORCESTER 24510 MD BALT.CITY 24999 MD (ALL) 25000 MA (UNSPECIF) 25001 MA BARNSTABLE 25003 MA BERKSHIRE 25005 MA BRISTOL 25007 MA DUKES 25009 MA ESSEX 25011 MA FRANKL IN 25013 MA HAMPOEN 25015 MA HAMPSHIRE
25017 MA MIDDLESEX 25019 MA NANTUCKET 25021 MA NORF JLK 25023 MA PLYMOUTH 25025 MA SUFFOLK 25027 MA WORCESTER 25999 MA (ALL) $26000 \mathrm{MI}$ (UNSPECIF) 26001 MI ALCONA $26003 \mathrm{MI}$ ALGER 26005 MI ALLEGAN $26007 \mathrm{MI}$ ALPENA 26009 MI ANTRIM 26011 MI ARENAC $26013 \mathrm{MI}$ BARAGA 26015 MI BARRY 26017 MI BAY 26019 MI BENZIE 26021 MI BERRIEN $26023 \mathrm{MI}$ BRANCH 26025 MI CALHOUN 26027 MI CASS 26029 MI CHARLEVOIX 26031 MI CHEBOYGAN $26033 \mathrm{MI}$ CHIPPEWA $26035 \mathrm{MI}$ CLARE 26037 MI CLINTON $26039 \mathrm{MI}$ CRAWFORD $26041 \mathrm{MI}$ DELTA 26043 MI DICKINSON $26045 \mathrm{MI}$ EATON $26047 \mathrm{MI}$ EMMET 26049 MI GENESEE $26051 \mathrm{MI}$ GLADWIN 26053 MI GOGEBIC 26055 MI GRAND TRAV $26057 \mathrm{MI}$ GRATIOT 26059 MI HILLSDALE 26061 MI HOUGHTON 26063 MI HURON 26065 MI INGHAM 26067 MI IONIA 26069 MI IOSCO 26071 MI IRON 26073 MI ISABELLA 26075 MI JACKSON 26077 MI KALAMAZOO 26079 MI KAL_KASKA 26081 MI KENT 26083 MI KEWEENAW 


\begin{tabular}{|c|c|c|}
\hline $\begin{array}{l}26085 \\
26087\end{array}$ & $\begin{array}{l}M I \\
M I\end{array}$ & $\begin{array}{l}\text { LAKE } \\
\text { LAPEER }\end{array}$ \\
\hline 26089 & MI & LEELANAU \\
\hline 26091 & MI & LENAWEE \\
\hline 26093 & MI & LIVINGSTON \\
\hline 5095 & MI & LUCE \\
\hline 26097 & MI & MACK INAC \\
\hline 26099 & MI & MACOMB \\
\hline 5101 & MI & MANISTEE \\
\hline Рค1ก.3 & MI & MARQUE TT TE \\
\hline 105 & MI & MASON \\
\hline 107 & MI & MECOSTA \\
\hline 5109 & MI & MENOMINEE \\
\hline & MI & MIDLAND \\
\hline$c$ & MI & MISSAUKEE \\
\hline & MI & MONROE \\
\hline 117 & MI & MONTCALM \\
\hline 119 & MI & MONTMORENC \\
\hline 21 & MI & MUSKEGON \\
\hline 123 & MI & NEWAYGO \\
\hline 125 & MI & OAKLAND \\
\hline & MI & OCE ANA \\
\hline 129 & MI & OGEMAW \\
\hline 131 & MI & ONTONAGON \\
\hline 33 & MI & OSCEOLA \\
\hline 135 & MI & OSCODA \\
\hline 137 & MI & OTSEGO \\
\hline 139 & Mï & OTTAWA \\
\hline 141 & MI & PRESQUE IS \\
\hline$\$ 143$ & MI & ROSCOMMON \\
\hline 145 & MI & $S \wedge G I N \wedge H$ \\
\hline 117 & MI & ST CLAIR \\
\hline 149 & MI & ST JOSEPH \\
\hline 151 & MI & SANILAC \\
\hline 153 & MI & SCHOOLCRAF \\
\hline & MI & SHI AWASSEE \\
\hline 157 & MI & IUSCOLA \\
\hline 159 & $1.1 \mathrm{I}$ & VAPN BUREN \\
\hline & MI & WASHTENAW \\
\hline 163 & MI & WAYNE \\
\hline & MI & WEXFORD \\
\hline & MI & ISLE ROYAL \\
\hline & MI & $(A L L)$ \\
\hline & MN & (UNSPEC IF) \\
\hline & MN & A I TK IN \\
\hline & $M N$ & ANOKA \\
\hline & MÑ & BECKER \\
\hline & MN & BELTRAM I \\
\hline & MN & BENTON \\
\hline & & \\
\hline
\end{tabular}

27013 MN BLUE EARTH 27015 MN BROWN 27017 MN CARLTON 27019 MN CARVER 27021 MN CASS 27023 MN CHIPPEWA 27025 MN CHISAGO 27027 MN CLAY 27029 MN CLEARWATER 27031 MN COOK 27033 MN COTTONWOOD 27035 MN CROW WING 27037 MN DAKOTA 27039 MN DODGE 27041 MN DOUGLAS 27043 MN FARIBAULT 27045 MN FILLMORE 27047 MN FREEBORN 27049 MN GOODHUE 27051 MN GRANT 27053 MN HENNEPIN 27055 MN HOUSTON 27057 MN HUBBARD 27059 MN ISANT I 27061 MN ITASCA 27063 MN JACKSON 27065 MN KANABEC 27067 MN KANDIYOHI 27069 MN KITTSON 27071 MN KOOCHICHIN 27073 MN LAC. DIII PA $27075 \mathrm{MN}$ I AKF 27077 MN LAKE OF TH 27079 MN LE SUEUR 27081 MN LINCOLN 27083 MN LYYN 27.7085 MN MC LEOD 27087 MN MAHNOMEN 27089 MN MARSHALL 27091 MN MARTIN 27093 MN MEEKER 27095 MN MILLE LACS 27097 MN MORRISON 27099 MN MOWER 27101 MN MURRAY 27103 MN NICOLLET 27105 MN NOBI.ES 27107 MN NORMAN 2\%109 MN OLMSTED 27111 MN OTTER TAIL
27113 MN PENNINGTON 27115 MN PINE

27117 MN PIPESTONE 27119 MN POLK 27121 MN POPE 27123 MN RAMSEY 27125 MN RED LAKE 27127 MN REDWOOD 27129 MN RENVILLE $27131 \mathrm{MN}$ RICE 27133 MN RUCK 27135 MN ROSEAU 27137 MN ST LOUIS 27139.MN SCOTT 27141 MN SHERBURNE 27143 MN SIBLEY 27145 MN STEARNS 27147 MN STEELL 27149 MN STEVENS 27151 MN SWIFT 27153 MN TODD 27155 MN TRAVERSE 27157 MN WABASHA 27159 MN WADENA 27161 MN WASECA 27163 MN WASHINGTON 27165 MN WATONWAN 27167 MN WILKIN 27169 MN WINONA 27171 MN WRIGHT P717.3 MN YELLOW MED $27999 \mathrm{MN}$ (ALL) 28000 MS (UNSPECIF) 28001 MS AПAMS 28003 MS ALCORN 28005 MS AMITE 28007 MS ATTALA 28009 MS BENTDN 28011 MS BOL IVAR ¿UU IS MS CALHUUN 28015 MS CARROLL 28017 MS CHICKASAW 28019 MS CHOCTAW 280ट1 MS CLAIBORNË 28023 MS CLARKE 28025 MS CLAY 28027 MS COAHOMA 28029 MS COP IAH 28031 MS COVINGTON 28033 MS DE SOTO 
28035 MS FORREST

28037 MS FRANKL IN 28039 MS GEORGE 28041 MS GREENE 28043 MS GRENADA 28045 MS HANCOCK 28047 MS HARR I SON 28049 MS HINDS 28051 MS HOLMES 28053 MS HUMPHREYS $28055 \mathrm{MS}$ ISSAQUENA 28057 MS I TAWAMBA 28059 MS JACKSON 28061 MS JASPER 28063 MS JEFFERSON 28065 MIS JEFF. DAVIS 28067 MS JONES 28069 MS KEMPER 28071 MS LAFAYETTE 28073 MS LAMAR 28075 MS LAUDERDALE 28077 MS LAWRENCE 28079 MS LEAKE 28081 MS LEE 28083 MS LEFLORE 28085 MS LINCOLN 28087 MS LOWNDES 28089 MS MADISON 28091 MS MARION 28093 MS MARSHALL 28095 MS MONROE 28097 MS MONTGOMERY 28099 MS NESHOBA 28101 MS NEWTON 28103 MS NOXUBEE 28105 MS OKT IBBEHA 28107 MS PANOLA 28109 MS PEARL RIVE 28111 MS PERRY 28113 MS PIKE 28115 MS PONTOTOC 28117 MS PRENTISS 28119 MS QUITMAN 28121 MS RANKIN 28123 MS SCOTT 28125 MS SHARKEY 28127 MS SIMPSON 28129 MS SMITH 28131 MS STONE 28133 MS SUNFLOWER
$28135 \mathrm{MS}$ TALLAHATCH 28137 MS TATE 28139 MS TIPPAH 28141 MS TISHOMINGO 28143 MS TUNICA 28145 MS UNION 28147 MS WALTHALL 28149 MS WARREN 28151 MS WASHINGTON 28153 MS WAYNE 28155 MS WEBSTER 28157 MS WILKINSON 28159 MS WINSTON 28161 MS YALOBUSHA. 28163 MS YAZOO $28999 M S$ (ALL) $29000 \mathrm{MO}$ (UNSPECIF) $29001 \mathrm{MO}$ ADAIR 29003 MO ANDREW $29005 M O$ ATCHISON 29007 MO AUDRAIN 29009 MO BARRY 29011 MO BARTON 29013 MO BATES 29015 MO BENTON 29017 MO BOLL INGER 290:9 MO BOONE $29021 \mathrm{MO}$ BUCHANAN 29023 MO BUTLER 29025 MO CALDWELL 29027 MO CALLAWAY 29029 MO CAMDEN 29031 MO CAPE GIRAR 29033 MO CARROLL 29035 MO CARTER 29037 MO CASS 29039 MO CEDAR 29041 MO CHARITON 29043 MO CHRISTIAN $29045 \mathrm{MO}$ CLARK 29047 MO CLAY 29049 MO CLINTON 29051 MO COLE 2.9ก5.3 MO C.NOPER 29055 MO CRAWF ORD 29057 MO DADE 29059 MO DALLAS $2906 !$ MO DAVIESS 29063 MO DE KALB 29065 MO DENT
29067 MO DOUGLAS 29069 MO DUNKL IN 29071 MO FRANKL IN 29073 MO GASCONADE 29075 MO GENTRY 29077 MO GREENE 29079 MO GRUNDY 29081 MO HARRISON 29083 MO HENRY 29085 MO HICKORY 29087 MO HOLT 29089 MO HOWARD 29091 MO HOWELL 29093 MO IRON 29095 MO JACKSON 29097 MO JASPER 29099 MO JEFFERSON 29101 MO JOHNSON 29103 MO KNOX 29105 MO LACLEDE 29107 MO LAFAYETTE 29109 MO LAWRENCE 29111 MO LEWIS 29113 MO LINCOLN 29115 MO LINN 29117 MO LIVINGSTON 29119 MO MC DONALD 29121 MO MACON 29123 MO MADISON 29125 MO MARIES 29127 MO MARION 29129 MO MERCER 29131 MO MILLER 29133 MO MISSISSIPP 29135 MO MONITEAU 29137 MO MONROE 29139 MO MONTGOMERY 29141 MO MORGAN 29143 MO NEW MADRID 29145 MO NEWTON 29147 MO NODAWAY 29149 MO OREGON 29151 MO OSAGE 29153 MO OZARK 29155 MO PEMISCOT 29157 MO PERRY 29159 MO PETTIS 29161 MO PHELPS 29163 MO PIKE 29165 MO PLATTE 
29167 MO POLK 29169 MO PULASKI 29171 MO PUTNAM 29173 MO RALLS 29175 MO RANDOLPH 29177 MO RAY 29179 MO REYNOLDS 29181 MO RIPLEY $29183 \mathrm{MO}$ ST CHARLES $29185 \mathrm{MU}$ SI CLAIK 29187 MO ST FRANCOI 29189 MO ST LOUIS 29193 MO STE GENEVI 29195 MO SAL INE $29197 \mathrm{MO}$ SCHUYLER $29199 \mathrm{MO}$ SCOTLAND 29201 MO SCOIT 29203 MO SHANNON $29205 \mathrm{MO}$ SHELBY $29207 M O$ STODDARD 29209 MO STONE 29211 MO SULI_IVAN 29213 MO TANEY 29215 MO TEXAS 292 17 MO VERNON 29219 MO WARREN 29221 MO WASHINGTON 29223 MO WAYNE 29225 MO WEBSTER 29227 MO WORTH 29229 MO WRIGHT 29510 MO ST LOUIS C $29999 M 0$ (ALL) 30000 MT (UNSPECIF) 30001 MT BEAVERHEAD 30003 MT BIG HORN 30005 MT BLAINE 30007 MT BROADWATER 30009 MT CARBON $30011 \mathrm{MT}$ CARTER 30013 MT C.ASC.ADE $30015 \mathrm{MT}$. CHOUTEAU 3UU1\% MT CUSTER 30019 MT DANIELS 30021 MT DAWSON $30023 \mathrm{MT}$ DEER LODGE 30025 MT FALLON 30027 I.T FERGUS 30029 MT FLATHEAD 30031 MT GALLAT IN
30033 MT GARF IELD

30035 MT GLACIER

30037 MT GOLDEN VAL

30039 MT GRANITE

30041 MT HILL

30043 MT JEFFERSON

30045 MT JUDITH BAS

30047 MT LAKE

30049 MT LEWIS AND

SUUSI MT LIBERTY

30053 MT LINCOLN

30055 MT MC CONE

30057 MT MADISON

30053 MT MEAGHER

30061 MT MINERAL

30063 MT Mi:JSOULA

30065 MT MUSSELSHEL

30067 MT PARK

30069 MT PETROLEUM

30071 MT PHILLIPS

30073 MT PONDERA

30075 MT POWDER RIV

30077 MT POWELL

30079 MT PRAIRIE

30081 MT RAVALLI

30083 MT RICHLAND

30085 MT ROOSEVELT

30087 MT ROSEBUD

30089 MT SANDERS

30091 MT SHERIDAN

30093 MT SILVER BOW

30095 MT STILLWATER

30097 MT SWEET GRAS

30099 MT TETON

30101 MT TOOLE

30103 MT TREASURE

30105 MT VALLEY

30107 MT WHEATLAND

30109 MT WIBAUX

30111 MT YELLOWSTON

3011.3 MT YFI, L. NAT $P$

30999 MT (ALL)

31000 NE (UNSPECIF)

31001 NE ADAMS

31003 NE ANTELOPE

31005 NE ARTHUR

31007 NE BANNER

31009 NE OLAINE

31011 NE BOONE

31013 NE BOX BUTTE
31015 NE BOYD

31017 NE BROWN 31019 NE BUFFALO

31021 NE BURT

31023 NE BUTLER

31025 NE CASS

31027 NE CEDAR

31029 NE CHASE

31031 NE CHERRY

31033 NE CHE'YENINE

31035 NE CLAY

31037 NE COLFAX

31039 NE CUMING

31041 NE CUSTER

31043 NE DAKOTA

31045 NE DAWES

31047 NE DAWSON

31049 NE DEUEL

31051 NE DIXON

31053 NE DODGE

31055 NE DOUGLAS

31057 NE DUNDY

31059 NE FILLMORE

31061 NE FRANKLIN

31063 NE FRONTIFR.

31065 NE FURNAS

31067 NE GAGE

31069 NE GARDEN

31071 NE GARF IELD

31073 NE GOSPER

31075 NE GRANT

31077 NE GREELEY

31079 NE HALL

31081 NE. HAMILTON

31083 NE HARLAN

31085 NE HAYES

31087 NE HITCHCOCK

31089 NE HOLT

31091 NE HOOKER

31093 NE HOWARD

31 M95 NF. IFFFFRSON

31097 NE JOHNSON

31099 NE KEARNE' $Y$ '

$31101 \mathrm{NE}$ KEITH

31103 NE KEYA PAHA

31105 NE KIMBALL

31107 NE KNOX

31109 NE LANCASTER

31111 NE LINCOLN

$31113 \mathrm{NE}$ LOGAN 
31115 NE LOUP 31117 NE MC PHERSON 31119 NE MADISON 31121 NE MERRICK 31123 NE MORRILL 31125 NE NANCE 31127 NE NEMAHA 31129 NE NUCKOLLS 31131 NE OTOE 31133 NE PAWNEE $311.35 \mathrm{NF}$ PFRKINS 31137 NE PHELPS 31139 NE PIERCE 31141 NE PLATTE 31143 NE POLK 31145 NE RED WILLOW 31147 NE RICHARDSON 31149 NE ROCK 31151 NE SALINE 31153 NE SARPY $31155 \mathrm{NE}$ SAUNDERS 31157 NE SCOTTS BLU 31159 NE SEWARD 31161 NE SHERIDAN 31163 NE SHERMAN 31165 NE SIOUX 31167 NE STANTON 31169 NE THAYER 31171 NE THOMAS 31173 NE THURSTON 31175 NE VALLEY 31177 NE WASHINGTON 31179 NE WAYNE 31181 NE WEBSTER 31183 NE WHEELER 31185 NE YORK 31999 NE (ALL) 32000 NV (UNSPEC IF) 32510 NV CARSON CIT 32001 NV CHURCHILL 32003 NV CLARK 32005 NV DOUCLAS 32007 NV ELKO 32009 NV ESMERALDA 32011 NV EUREKA 32013 NV HUMBOLDT 32015 NV LANDER 32017 NV LINCOLN 32019 NV LYON 32021 NV MINERAL
32023 NV NYE 32027 NV PERSHING 32029 NV STOREY 32031 NV WASHOE 32033 NV WHITE PINE 32999 NV (ALL) $33000 \mathrm{NH}$ (UNSPECIF) $33001 \mathrm{NH}$ BELKNAP $33003 \mathrm{NH}$ CARROLL $33005 \mathrm{NH}$ CHESHIRE 3.3007 NH C.OOS $33009 \mathrm{NH}$ GRAFTON $33011 \mathrm{NH}$ HILLSBOROU $33013 \mathrm{NH}$ MERRIMACK. 33015 NH ROCKINGHAM $33017 \mathrm{NH}$ STRAFFORD $33019 \mathrm{NH}$ SULL! VAN $33999 \mathrm{NH}$ (ALL) $34000 \mathrm{NJ}$ (UNSPECIF) 34001 NJ ATLANTIC 34003 NJ BERGEN 34005 NJ BURL INGTON 34007 NJ CAMDEN $34009 \mathrm{NJ}$ CAPE MAY 34011 NJ CUMBERLAND 34013 NJ ESSEX 34015 NJ GLOUCESTER 34017 NJ HUDSON 34019 NJ HUNTERDON 34021 NJ MERCER 34023 NJ MIDDLESEX 34025 NJ MONMOUTH $34027 \mathrm{NJ}$ MORRIS 34029 NJ OCEAN 34031 NJ PASSAIC 34033 NJ SALEM $34035 \mathrm{NJ}$ SOMERSET 34037 NJ SUSSEX 34039 NJ UNION 34041 NU WARREN $34999 \mathrm{NJ}$ ( $A L L$ ) 35000 NM (UNSPEC IF) 35001 NM BERNAL ILLO 35003 NM CATRON 35005 NM CHAVES 35007 NM COLFAX 35009 NM CURRY 35011 NM DE BACA 35013 NM DONA ANA 35015 NM EDOY
35017 NM GRANT 35019 NM GUADALUPE 35021 NM HARDING 35023 NM HIDALGO 35025 NM LEA 35027 NM LINCOLN 35028 NM LOS ALAMOS 35029 NM LUNA 35031 NM MC KINLEY 35033 NM MORA 35035 NM OTERO 35037 NM QUAY 35039 NM RIO ARRIBA 35041 NM ROOSEVELT 35043 NM SANDOVAL 35045 NM SAN JUAN 35047 NM SAN MIGUEL 35049 NM SANTA FE 35051 NM SIERRA 35053 NM SOCORRO 35055 NM TAOS 35057 NM TORRANCE 35059 NM UNION 35061 NM VALENCIA 35999 NM (ALL) 36000 NY (UNSPECIF) 36001 NY ALBANY 36003 NY ALLEGANY 36005 NY BRONX 36007 NY BROOME 36009 NY CATTARAUGU 36011 NY CAYUGA 36013 NY CHAUTAUQUA 36015 NY CHEMUNG 36017 NY CHENANGO 36019 NY CLINTON 36021 NY COLUMBIA 36023 NY CORTLAND 36025 NY DELAWARE 36027 NY DUTCHESS 36029 NY ERIE 36031 NY ESSEX 36033 NY FRANKL IN 36035 NY FULTON 36037 NY GENESEE 36039 NY GRFFNE. 36041 NY HAMILTON 36043 NY HERKIMER 36045 NY JEFFERSON 36047 NY KINGS 
36049 NY LEWIS 36051 NY LIVINGSTON 36053 NY MADISON 36055 NY MONROE 36057 NY MONTGOMERY 36059 NY NASSAU 36061 NY NEW YORK 36063 NY NI AGARA 36065 NY ONE IDA 36067 NY ONONDAGA 36069 NY ONTARIO 36071 NY ORANGE 36073 NY ORLEANS 36075 NY OSWEGO 36077 NY OTSEGO 36079 NY PUTNAM 36081 NY QUEENS 36083 NY RENSSELAER 36085 NY RICHMOND 36087 NY ROCKLAND 36089 NY ST LAWRENC 36091 NY SARATOGA 36093 NY SCHENECTAD 36095 NY SCHOHARIE 36097 NY SCHUYLER 36099 NY SENECA 36101. NY STEUBEN 36103 NY SUFFOLK 36105 NY SULLIVAN 36107 NY TIOGA $36109 \mathrm{NY}$ TOMPKINS 36111 N'Y ULSTER 36113 NY WARREN 36115 NY WASHINGTON 3E! 17 NY WAYNE 36119 NY WESTCHESTE 36I? 1 NY WYOMINE 36123 NY YATES 36999 NY (ALL) 37000 NC (UNSPEC IF) 37001 NC ALAMANCE 37003 NC ALEXANDER 37005 NC ALLEOHANY' 37007 NC ANSON 37009 NC ASHE 37011 NC AVERY 37013 NC BEAUFORT 37015 NC. BF.RTIE 37017 NC BLADEN 37019 NC BRUNSWICK
37021 NC BUNCOMBE 37023 NC BURKE 37025 NC CABARRUS 37027 NC CALDWELL 37029 NC CAMDEN 37031 NC CARTERET 37033 NC CASWELL 37035 NC CATAWBA 37037 NC CHATHAM 37039 NC CHEROKEE 37041 NC CHOWAN 37043 NC CLAY 37045 NC CLEVELAND 37047 NC COLUMBIJS 37049 NC CRAVEN 37051 NC CUMBERLAND 37053 NC CURRI TUCK. 37055 NC DARE 37057 NC DAVIDSON 37059 NC DAVIE 37061 NC DUPLIN 37063 NC DURHAM 37065 NC EDGECOMBE 37067 NC FORSYTH 37069 NC FRANKL IN 37071 NC GASTON 37073 NC GATES 37075 NC GRAHAM 37077 NC GRANV ILLE 37079 NC GREENE 37081 NC GUILFORD 37083 NNC HALIFAX 37085 NC HARNETT 37087 NC HAYWOOD 37089 NC HENDERSON 37091 NC HERTFORD 37093 NC HOKE 37095 NC HYOE 37097 NC. IRELELL 37099 NC JACKSON 37101 NC JOHNSTON 37103 NC JONES 37105 NC LEE 37107 NC LENOIR 37109 NC LINCOLN 37111 NC MC DOWELL 37113 NC MACON 37115 NC MADISON 37117 NC MART IN 37119 NC MECKLENBUR
37121 NC MITCHELL 37123 NC MONTGOMERY 37125 NC MOORE 37127 NC NASH 37129 NC NEW HANOVE 37131 NC NORTHAMPTO 37133 NC ONSLOW 37135 NC ORANGE 37137 NC PAML ICO 37139 NC PASQUOTANK. 37141 NC PENDER 37143 NC PERQUIMANS 37145 NC PERSON 37147 NC.PITT 37149 NC POLK 37151 NC RANDOLPH 37153 NC RICHMOND 37155 NC ROBESON 37157 NC ROCKINGHAM 37159 NC ROWAN 37161 NC RUTHERFORD 37163 NC SAMPSON 37165 NC SCOTLAND 37167 NC STANLY 37169 NC STOKES $37171 \mathrm{NC}$ SURRY 37173 NC SWAIN 37175 NC TRANSYLVAN 37177 NC TYRRELL. 37179 NC UNION 37181 NC VANCE 37183 NNC WAKE 37185 NC WARREN 37187 NC WASHINGTON 31189 NC WATAUGA 37191 NC WAYNE 37193 NC WILKES 37195 NC WILSON 37197 NC YADKIN 37199 NC YANCEY 37201 NC OUTER BANK 37999 NC (ALL) 38000 ND (INNGPECIF) 38001 ND ADAMS 38003 ND BARNES 38005 ND BENSON 38007 ND BILLINGS 38009 ND BOTTINEAU 38011 ND BOWMAN 38013 ND BURKE 


\begin{tabular}{|c|c|c|}
\hline & & \\
\hline & ND & CASS \\
\hline 38019 & ND & CAVAL IER \\
\hline & ND & \\
\hline & ND & DIVIDE \\
\hline & ND & DUNN \\
\hline & ND & EDDY \\
\hline & ND & EMMONS \\
\hline & ND & FOSTER \\
\hline & ND & GOLDFN VAL \\
\hline & ND & GRAND FORK \\
\hline & ND & GRANT \\
\hline & ND & GRIGGS \\
\hline & ND & HET T I NGER \\
\hline & ND & KIDDER \\
\hline & ND & LA MOURE \\
\hline & ND & LOGAN \\
\hline & ND & MC HENRY \\
\hline & ND & MC INTOSH \\
\hline & ND & MC KENZIE \\
\hline & ND & MC LEAN \\
\hline & ND & MER ,ER \\
\hline & ND & MORT ON \\
\hline & ND & MOUNTRAIL \\
\hline & ND & NELSON \\
\hline & ND & OL I VER \\
\hline & ND & PEMBINA \\
\hline & ND & PIERCE \\
\hline & ND & RAMSEY \\
\hline & ND & RANSOM \\
\hline & ND & RENV ILLE \\
\hline & ND & RICHLAND \\
\hline & ND & ROLETTE \\
\hline & ND & SARGENT \\
\hline & ND & SHER IDAN \\
\hline & ND & SIOU \\
\hline & ND & SLOPE \\
\hline & ND & STARK \\
\hline & ND & STEELE \\
\hline & ND & STUTSMAN \\
\hline & ND & TOWNER \\
\hline & NO & TRAILL \\
\hline & $\mathrm{ND}$ & WALSH \\
\hline & ND & WARD \\
\hline & ND & WELLS \\
\hline & ND & WILL I AMS \\
\hline & & (ALL) \\
\hline & & \\
\hline & & \\
\hline & & \\
\hline
\end{tabular}

39005 OH ASHLAND

39007 OH ASHTABULA

39009 OH ATHENS

39011 OH AUGLAIZE

39013 OH BELMONT

$39015 \mathrm{OH}$ BROWN

39017 OH BUTLER

39019 OH CARROLL

39021 OH CHAMPAIGN

$39023 \mathrm{OH}$ CLARK

39025 OH CLERMONT

39027 OH CLINTON

$39029 \mathrm{OH}$ COLUMBIANA

$39031 \mathrm{OH}$ COSHOCTON.

39033 OH CRAWFORD

$39035 \mathrm{OH}$ CUYAHOGA

39037 OH DARKE

39039 OH DEF I ANCE

$39041 \mathrm{OH}$ DELAWARE

39043 OH ERIE

39045 OH FAIRF IELD

39047 OH FAYETTE

39049 OH FRANKL IN

39051 OH FULTON

39053 OH GALLIA

39055 OH GEAUGA

39057 OH GREENE

39059 OH GUERNSEY

39061 OH HAMILTON

$39063 \mathrm{OH}$ HANCOCK

39065 OH HARDIN

39067 OH HARRISON

39069 OH HENRY

$39071 \mathrm{OH}$ HIGHLAND

39073, OH HOCKING

$39075 \mathrm{OH}$ HULMES

39077 OH HURON

39079 OH JACKSON

39081 OH JEFFERSON

$39083 \mathrm{OH}$ KNOX

39085 OH LAKE

$39087 \mathrm{OH}$ LAWRENCE

39089 OH LICKING

39091 OH LOGAN

39093 OH LORAIN

39095 OH LUCAS

39097 OH MADISON

39099 OH MAHONING

39101 OH MARION

39103 OH MEDINA
$39105 \mathrm{OH}$ MEIGS

39107 OH MERCER

$39109 \mathrm{OH}$ MIAMI

39111 OH MONROE

$39113 \mathrm{OH}$ MONTGOMERY

$39115 \mathrm{OH}$ MORGAN

$39117 \mathrm{OH}$ MORROW

$39119 \mathrm{OH}$ MUSK INGUM

39121. OH NOBLE

39123 OH OTTAWA

$39125 \mathrm{OH}$ PAULDING

$39127 \mathrm{OH}$ PERRY

39129 OH PICKAWAY

39131 OH PIKE

$39133 \mathrm{OH}$ PORTAGE

39135 OH PREBLE

39137 OH PUTNAM

39139 OH RICHLAND

39141 OH ROSS

$39143 \mathrm{OH}$ SANDUSKY

39145 OH SCIOTO

39147 OH SENECA

39149 OH SHELBY

$39151 \mathrm{OH}$ STARK

$39153 \mathrm{OH}$ SUMMIT

$39155 \mathrm{OH}$ TRUMBULL

39157 OH TUSCARAWAS

39159 OH UNION

39161 OH VAN WERT

$39163 \cdot$ OH VINTON

$3916.5 \mathrm{OH}$ WARREN

39167 OH WASHINGTON

39169 OH WAYNE

39171 OH WILLIAMS

39173 OH WOOD

39175 OH WYANDOT

39999 OH (ALL)

40000 OK (UNSPECIF)

40001 OK ADAIR

4 UDク3 OK ALFALFA

40005 OK ATOKA

40007 OK BEAVER

40009 OK BECKHAM

40011 OK BLAINE

40013 OK BRYAN

40015 OK CADDO

40017 OK CANADIAN

40019 OK CARTER

40021 OK CHEROKEE

40023 OK CHOCTAW 


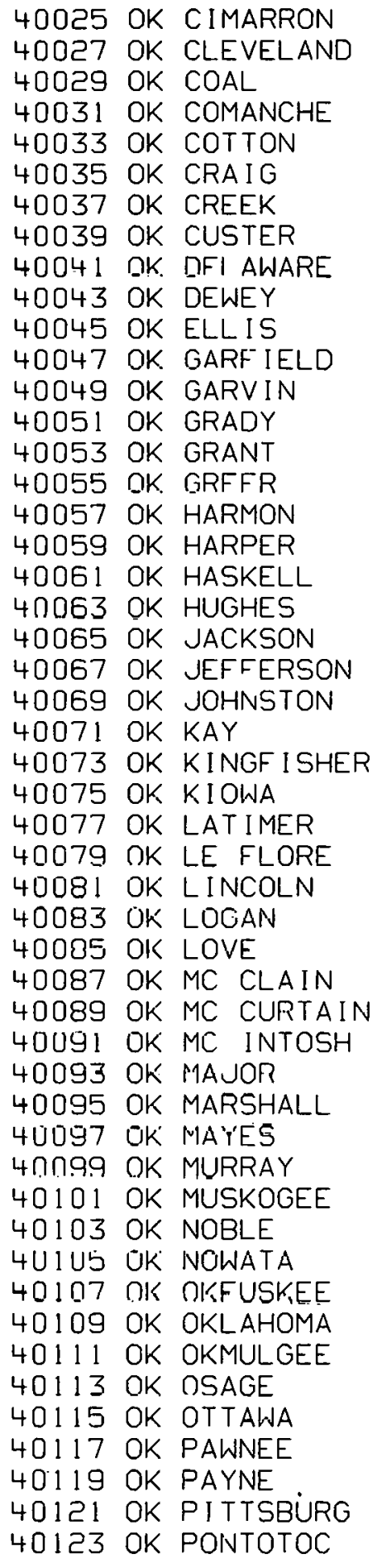

\author{
40125 OK POTTAWATOM \\ 40127 OK PUSHMATAHA \\ 40129 OK ROGER MILL \\ 40131 OK ROGERS \\ 40133 OK SEMINOLE \\ 40135 OK SEQUOYAH \\ 40137 OK STEPHENS \\ 40139 OK TEXAS \\ 40141 OK TILLMAN \\ 401.43 OK TULSA \\ 40145 OK WAGONER \\ 40147 OK WASHINGTON \\ 40149 OK WASHITA \\ 40151 OK WOODS \\ 40153 OK WOODWARD \\ 40999 OK (ALL) \\ 41000 OR (UNSPECIt) \\ 41001 OR BAKER \\ 41003 OR BENTON \\ 41005 OR CLACKAMAS \\ 4IUU / UR LLATSOP \\ 41009 OR COLUMBIA \\ 41011 OR COOS \\ 41013 OR CROOK \\ 41015 QR CURRY \\ 41017 OR DESCHUTES \\ 41019 OR DOUGLAS \\ 41021 OR GILLIAM. \\ 41023 OR GRAN1 \\ $410 E S$ OR HARINEY \\ $41 \cap 27$ OR HOOD RIVER \\ 41029 OR JACKSON \\ 41031 OR JEFFERSON \\ 41033 OR JOSEPHINE \\ 41035 ПR KI AMATH \\ 41037 OR LAKE \\ 11039 OR LANE \\ 41041 OR LINCOLN \\ 41043 OR LINN \\ 41045 OR MALHEUR \\ 41017 OR MARION \\ 41049 OR MORROW \\ 41051 OR MUL TNUMAH \\ 41053 OR POLK \\ 41055 CR SHERMAN \\ 41057 OR TILLAMOOK \\ 41059 OR UMATILLA \\ 41061 OR UNION \\ 41063 OR WALLOWA \\ 41065 OR WASCO
}

\author{
41067 OR WASHINGTON \\ 41069 OR WHEELER \\ 41071 OR YAMHILL \\ 41999 OR (ALL) \\ 42000 PA (UNSPECIF) \\ 42001 PA ADAMS \\ 42003 PA ALLEGHENY \\ 42005 PA ARMSTRONG \\ 42007 PA BEAVER \\ 42009 PA BEDFORD \\ 42011 PA BERKS \\ 42013 PA BLAIR \\ 42015 PA BRADFORD \\ 42017 PA BUCKS \\ 42019 PA BUTLER \\ 42021 PA CAMBRIA \\ 42023 PA CAMERON \\ 42025 PA CARBON \\ 42027 PA CENTRE \\ 42029 PA CHESTER \\ 4 LOJ1 TA CLARION \\ 42033 PA CLEARF IELD \\ 42035 PA CLINTON \\ 42037 PA COLUMBIA \\ 42039 PA CRAWFORD \\ 42041 PA CUMBERLAND \\ 42043 PA DAUPHIN \\ 42045 PA DELAWARE \\ 42047 PA ELK \\ 42049 PA ERIE \\ 42051 PA FAYETTE \\ 42053 PA FORESI \\ 42055 PA FRANKL IN \\ 42057 PA FULTON \\ 42059 PA GREENE \\ 42061 PA HUNTINGDON \\ H?RF.Z PA INDI ANA \\ 42065 PA JEFFERSON \\ 42067 PA JUPIATA \\ 42069 PA LACKAWANNA \\ 42071 PA LANCASTER \\ 42073 PA LAWRENCE \\ 42075 PA LEBANUN \\ 42077 PA LEHIGH \\ 42079 PA LUZERNE \\ 42081 PA LYCOMING \\ 42083 PA MC KENN \\ 42005 PA MERCER \\ 42087 PA MIFFL IN \\ 't2089 PA MONROE
}


42091 PA MONTGOMERY 42093 PA MONTOUR 42095 PA NORTHAMPTO 42097 PA NORTHUMBER 42099 PA PERRY

42101 PA PHILADELPH 42103 PA PIKE 42105 PA POTTER 42107 PA SCHUYLKILL 42109 PA SNYDER 42111 PA SOMERSET 42113 PA SULLIVAN 42115 PA SUSQUEHANN 42117 PA TIOGA 42119 PA UNION 42121 PA VENANGO 42123 PA WARREN 42125 PA WASHINGTON 42127 PA WAYNE 42129 PA WESTMORELA 42131 PA WYOMING 42133 PA YORK 42999 PA (ALL) 43000 PR PUERTO RIC 43001 PR MAIN ISLAN 43003 PR CULEBRA I. 43005 PR DESECHEO I 43007 PR ICACOS I. 43009 PR MONA I. 43011 PR MONITO I. 43013 PR MUERTOS I. 43015 PR PALOMINOS 43017 PR PINEROS I. 43019 PR VIEQUES I. 43021 PR DTHER PR 43101 PR ADJUNTAS 43102 PR AGUADA 43103 PR AGUADILLA 43104 PR AGUAS BUEN 43105 PR AIBONITO 43106 PR ANASCO 43107 PR ARECIBO 43108 PR ARROYO 43109 PR BARCELONET 43110 PR BARRANQUIT 43111 PR BAYAMON 4311 2 PR CABO ROJO 43113 PR CAGUAS 43114 PR CAMUY 43115 PR CAROL INA
43116 PR CATANO

43117 PR CAYEY

43118 PR CEIBA

43119 PR CIALES

43120 PR CIDRA

43121 PR COAMO

43122 PR COMERIO

43123 PR COROZAL

43124 PR DORADO

43125 TR FAJARDO

43126 PR GUANICA

43127 PR GUAYAMA

43128 PR GUAYANILLA

43129 PR GUAYNABO

43130 PR GURABO

43131 PR HAT ILLO

43132 PR HORMIGUERO

43133 PR JUMACAO

43134 PR ISABELA

43135 PR JAYUYA

43136 PR JUANA DIAZ

43137 PR JUNCOS

43138 PR LAJAS

43139 PR LAFEES

43140 PR LAS MARIAS

43141 PR LAS PIEDRA

43142 PR LOIZA

.43143 PR LUQUILLO

43144 PR MANATI

43145 PR MARICAO

43146 PR MAUNABO

43147 PR MAYAGUEZ

43148 PR MOCA

43149 PR MOROVIS

43150 . PR NAGUABO

43151 PR NARANUITO

43152 PR OROCOVIS

43153 PR PATILLAS

43154 PR PENUELAS

43155 PR PONCE

43156 PR QUEBRAOILL

43157 PR RINCON

43158 PR RIO GRANDE

43159 PR RIO PIEDRA

43160 PR SABANA GRA

43161 PR SALINAS

43162 PR SAN GERMAN

43163 PR SAN JUAN

43164 PR SAN LORENZ

43165 PR SAN SEBAST
43166 PR SANTA ISAB

43167 PR TOA ALTA

43168 PR TOA BAJA

43169 PR TRUJILLO A

43170 PR UTUADO

43171 PR VEGA ALTA

43172 PR VEGA BAJA

43173 PR VILLALBA

43174 PR YABUCOA

43175 PR YAUCO

43999 PR (ALL)

44000 RI (UNSPECIF)

44001 RI BRISTOL

44003 RI KENT

44005 RI NEWPORT

44007 RI PROVIDENCE

44009 RI WASHINGTON

44999 RI (ALL)

45000 SC (UNSPECIF)

45001 SC ABBEVILLE

45003 SC AIKEN

45005 SC ALLENDALE

45007 SC ANDERSON

45009 SC BAMBERG

45011 SC BARNWELL

45013 SC BEAUFORT

45015 SC BERKELEY

45017 SC CALHOUN

45019 SC CHARLESTON

45021 SC CHEROKEE

45023 SC CHESTER

45025 SC CHESTERF IE

45027 SC CLARENDON

45029 SC COLLETON

45031 SC DARLINGTON

15033 SC DILLON

45035 SC DORCHESTER

45037 SC EDGEF IELD

45039 SC FAIRF IELD

45041 SC FLORENCE

45043 SC GEORGETOWN

45045 SC GREENVILLE

45047 SC GREENWOOD

45049 SC HAMPTON

45051 SC HORPY

45053 SC JASPER

45055 SC KERSHAW

45057 SC LANCASTER

45059 SC LAURENS

45061 SC LEE 


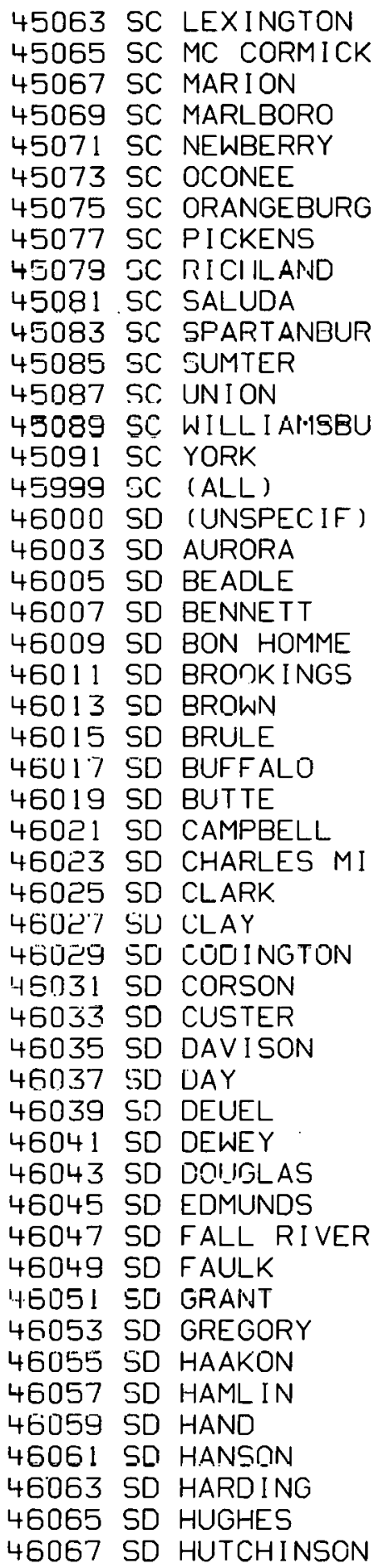

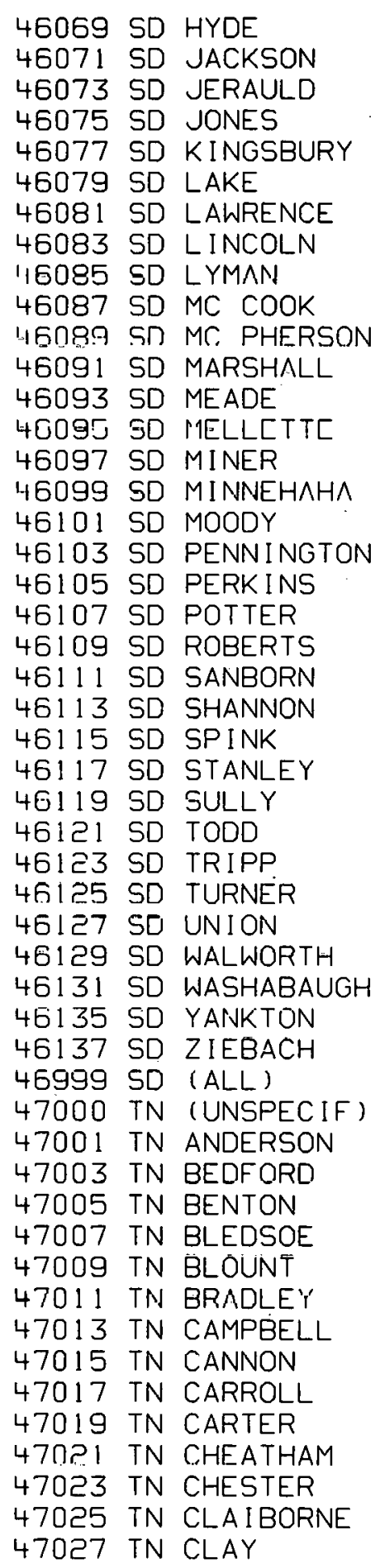

47029 TN COCKE

47031 TN COFFEE

47033 TN CROCKETT

47035 TN CUMBERLAND

47037 TN DAVIDSON

47039 TN DECATUR

47041 TN DE KALB

47043 TN DICKSON

47045 TN DYER

47047 TN FAYETTE

47049 TN FENTRESS

47051 TN FRANKLIN

47053 TN GIBSON

177055 TN CILCE

47057 TN GRAINGER

47059 TN GREENE

47061 TN GRUNDY

47063 TN HAMBLEN

47065 TN HAMILTON

47067 TN HANCOCK

47069 TN HARDEMAN

47071 TN HARDIN

47073 TN HAWKINS

47075 TN HAYWOOD

47077 TN HENDERSON

47079 TN HENRY

47081 TN HICKMAN

47083 TN HOUSTON

47085 IN HUMPHREYS

47087 TN JACKSON.

47089 TN JEFFERSON

47091 TN JOHNSON

47093 TN KNOX

47095 TN LAKE

47097 TN LAUDERDALE

47099 TN LAWRENCE

47101 TN LEWIS

4710.3 TN LINCOLN

47105 TN LOUDON

47107 TN MC MINN

47109 TN MC NAIRY

47111 TN PACON

47113 TN MADISON

47115 TN MARION

47117 TN MARSHALL

47119 TN MAURY

47121 TN MEIGS

47123 TN MONROE

47125 TN MONTGOMERY

47127 TN MOORE 
47129 TN MORGAN

47131 TN OBION

47133 TN OVERTON

47135 TN PERRY

47137 TN PICKETT

47139 TN POLK

47141 TN PUTNAM

47143 TN RHEA

47145 TN ROANE

47147 TN ROBERTSON

47149 TN RUTHERFORD

47151 TN SCOTT

47153 TN SEQUATCHIE

47155 TN SEVIER

47157 TN SHELBY

47159 TN SMITH

47161 TN STEWART

47163 TN SULLIVAN

47165 TN SUMNER

47167 TN TIPTON

47169 TN TROUSDALE

47171 TN UNI R.OI

47173 TN UNION

47175 TN VAN BUREN

47177 TN WARREN

47179 TN WASHINGTON

47181 TN WAYNE

47183 TN WEAKLEY

47185 TN !U!HITE

47187 TN WILLIAMSON

47189 TN WILSON

47999 TN (ALL)

48000 TX (UNSPECIF)

48001 TX ANDERSON

48003 TX ANDREWS

48005 TX ANCLLINA

48007 TX ARANSAS

48009 TX ARCHER

48011 TX ARMSTRONG

48013 TX ATASCOSA

48015 TX AUSTIN

48017 TX BAILEY

48019 TX BANDERA

48021 TX BASTROH

48023 TX BAYLOR

48025 TX BEE

48027 TX BELL

48029 TX BEXAR

48031 TX BLANCO

48033 TX BORDEN
48035 TX BOSQUE

48037 TX BOWIE

48039 TX BRAZORIA

48041 TX BRAZOS

48043 TX BREWSTER

48045 TX BRISCOE

$48047^{\circ}$ TX BROOKS.

48049 TX BROWN

48051 TX BURLESON

48053 TX BURNET

48055 TX CALDWELL

48057 TX CALHOUN

48059 TX CALLAHAN

48061 TX CAMERON

48063 TX CAMP

48065 TX CARSON

48067 TX CASS

48069 TX CASTRO

48071 TX CHAMBERS

48073 TX CHEROKEE

48075 TX CHILDRESS

48077 TX CLAY

48079 TX COCHRAN

48081 TX COKE

48083 TX COLEMAN

48085 TX COLLIN

48087 TX COLL INGSWO

48089 TX COLORADO

48091 TX COMAL

48093 TX COMANCHE

$48095 \mathrm{TX}$ CONCHO

48097 TX COOKE

48099 TX CORYELL

48101 TX COTTLE

48103 TX CRANE

1.18105 TX CROCKETT

$4 \dot{8107}$ TX CROSBY

48109 TX CULBERSON

48111 TX DALLAM

48113 TX DALLAS

48115 TX DAWSCN

48117 TX DEAF SMITH

48119 TX DELTA

48121 TX DENTON

48123 TX DE WITT

481 ES TX DICKENS

48127 TX DIMMIT

48129 TX DONLEY

48131 TX DUVAL

48133 TX. EASTLAND
48135 TX ECTOR

48137 TX EDWARDS

48139 TX ELLIS

48141 TX EL PASO

48143 TX ERATH

48145 TX FALLS

48147 TX FANNIN

48149 TX FAYETTE

48151 TX FISHER

48153 TX "FLOYD

48155 TX FOARD

48157 TX FORT BEND

48159 TX FRANKLIN

48161 TX FREESTONE

48163 TX FRIO

48165 TX GAINES

48167 TX GALVESTON

48169 TX GARZA

48171 TX GILLESPIE

48173 TX GLASSCOCK

48175 TX GOL IAD

48177 TX GONZALES

48179 TX GRAY

48181 TX GRAYSON

48183 TX GREGG

48185 TX GRIMES

48187 TX GUADALUPE

48189 TX HALE

48191 TX HALL

48193 TX HAMILTON

48195 TX HANSFORD

48197 TX HARDEMAN

48199 TX HARDIN

48201 TX HARRIS

48203 TX HARR ISON

18205 TX HARTLEY

48207 TX HASKELL

48209 TX HAYS

48211 TX HEMPHILL

48213 TX HENDERSON

48215 TX HIDALGO

48217 TX HILL

48219 TX HOCKLEY

48221 IX HUOU

48223 'TX HOPKINS

48225 TX HOUSTON

48227 TX HOWARD

48229 TX HUOSPETH

48231 TX HUNT

48233 TX HUTCHINSON 
DISTRIBUT ION CODES

PAGE 20

\begin{tabular}{|c|c|c|c|c|c|c|c|c|}
\hline 48235 & $T X$ & IRION & 48335 & $T X$ & MI TCHELL & 48435 & $T X$ & SUTTON \\
\hline 8237 & TX & JACK & 48337 & $T X$ & MONTAGUE & 48437 & $T X$ & SWI SHER \\
\hline 48239 & $T X$ & JACKSON & 48339 & $T X$ & MONTGOMERY & 48439 & $T X$ & TARRANT \\
\hline 48241 & $T X$ & JASPER & 48341 & $T X$ & MOORE & 48441 & $T X$ & TAYLOR \\
\hline 8243 & $T X$ & JEFF DAVIS & 48343 & $T X$ & MORR IS & 48443 & $T X$ & TERRELL \\
\hline 48245 & $T X$ & JEFFERSON & 48345 & $T X$ & MOTLEY & 48445 & $\mathrm{TX}$ & TERRY \\
\hline 48247 & TX & JIM HOGG & 48347 & $T X$ & NACOGDOCHE & 48447 & $T X$ & THROCKMORT \\
\hline 8249 & TX & JIM WELLS & 48349 & $T X$ & NAVARRO & 48449 & $T X$ & TITUS \\
\hline +82こ 1 & $T X$ & JOI INJSON & 4835.1 & $T X$. & NEWTTEN & 48451 & $T X$ & TOM GREEN \\
\hline 48253 & $T X$ & JONES & 48353 & $T X$ & NOLAN & 48453 & $T X$ & TRAVIS \\
\hline 48255 & $T X$ & KARNES & 48355 & $T X$ & NUECES & 48455 & $T X$ & TR INITY \\
\hline 48257 & $T X$ & KAUFMAN & 48357 & $T X$ & OCHILTREE & 48457 & $T X$ & TYLER \\
\hline 48259 & $T X$ & KENDALL & 48359 & $T X$ & OLDHAM & 48459 & $T X$ & UPSHUR \\
\hline 48261 & $T X$ & KENEDY & 48361 & TX & ORANGE & 48461 & $T X$ & UPTON \\
\hline 48263 & TX & KENT & 48363 & $T X$ & PALO PINTO & 48463 & $T X$ & UVALDE \\
\hline 48265 & TX & KERR & 48365 & $T X$ & PANDLA & 48465 & $T X$ & VAL VERDE \\
\hline 48267 & $T X$ & KIMBLE & 48367 & $T X$ & PARKER & 48467 & $T X$ & VAN ZANDT \\
\hline 48269 & $\mathrm{TX}$ & KING & 48369 & $T X$ & PARMER & 48469 & $T X$ & VICTORIA \\
\hline 48271 & $T X$ & KINNEY & 48371 & $T X$ & PECOS & 48471 & $T X$ & WALKER \\
\hline 48273 & $T X$ & KLEBERG & 48373 & TX & POLK & 48473 & $T X$ & WALLER \\
\hline 48275 & $T X$ & KNOX & 48375 & $T X$ & POTTER & $48+75$ & $\mathrm{TX}$ & WARD \\
\hline 48277 & $T X$ & LAMAR & 48377 & $T X$ & PRESIDIO & 48477 & $T X$ & WASHINGTON \\
\hline 48279 & $T X$ & LAMB & 48379 & $T X$ & RAINS & 48479 & $T X$ & WEBB \\
\hline 48281 & $\mathrm{TX}$ & LAMPASAS & 48381 & $T X$ & RANDALL & 48481 & $T X$ & WHARTON \\
\hline 48283 & $T X$ & LA SALLE & 48383 & $T X$ & REAGAN & $1+8483$ & $T X$ & WHEELER \\
\hline 48285 & $T X$ & LAVACA & 48385 & $T X$ & REAL & 48485 & $T X$ & WICHITA \\
\hline 48287 & $T X$ & LEE & 48387 & $T X$ & RED RIVER & 48487 & $T X$ & WILBARGER \\
\hline 48289 & $T X$ & LEON & 48389 & $T X$ & REFVES & 48489 & $T X$ & WILLACY \\
\hline 48291 & $T X$ & LIBERTY & 48391 & $T X$ & REFUG IO & 48491 & $T X$ & WILL I AMSON \\
\hline 48293 & IX & L IMESTUNE & 48393 & $T X$ & ROBEFTS & 30 & $T X$ & .. ILSON \\
\hline 48295 & $T x$ & LIPSCOI"IB & 483 & $T X$ & RODLRTSON & 49495 & $T X$ & 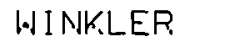 \\
\hline 97 & TX & LIVE OAK & 48397 & $T X$ & ROCKWALL & 48497 & $T X$ & WISE \\
\hline 48299 & $T X$ & LLANO & 48399 & $T X$ & RUNNELS & 48499 & $T X$ & WOOD \\
\hline 48301 & $T X$ & LOVING & 48401 & IX & RUSK & 48501 & $T X$ & YOAKUM \\
\hline 48.3115 & Ix & LUBBOCK & 48403 & $T X$ & SABINL & 18503 & $T X$ & YOUNG \\
\hline 05 & $T X$ & I YNN & $48405^{\circ}$ & $T X$ & SAN AUGUST & 48505 & $T X$ & ZAPATA \\
\hline 48307 & $T X$ & MC CULLOCH & 48407 & $T X$ & SAN JACINT & $48 \overline{507}$ & $T x^{\prime}$ & ZAVALA \\
\hline 309 & $T X$ & MC LENNAN & 48409 & $T X$ & SAN PATRIC & 48601 & $T X$ & PADRE I. \\
\hline & $T X$ & MC MULLEN & 48411 & $T X$ & SAN SABA & 48999 & $T X$ & $(A L L)$ \\
\hline 48 & $T X$ & MADISON & 48413 & $T X$ & SCHLE I CHER & 49000 & UT & (UNSPEC IF) \\
\hline & $\mathrm{TX}$ & MARION & 48415 & $I X$ & SCURRY & 49001 & UT & BEAVER \\
\hline 817 & $T X$ & MART IN & 48417 & $T X$ & SIACKKFIFOR & 49003 & UT & BOX, ELDER \\
\hline 48319 & $T X$ & MASON & 48419 & $T X$ & SHELBY & 49005 & UT & CACHE \\
\hline & $T X$ & MATAGORDA & 48421 & $T X$ & SHERMAN & 49007 & UT & CARBON \\
\hline 23 & $T X$ & MAVERICK & 48423 & $T X$ & SMITH & 49009 & UT & DAGGETT \\
\hline 48325 & $T X$ & MEDINA & 48425 & $T X$ & SOMERVELL & 43011 & UT & DAVIS \\
\hline 48327 & $T X$ & MENARD & 48427 & $T X$ & STARR & 49013 & UT & DUCHESNE \\
\hline & $T X$ & MIDLAND & 48429 & $T X$ & STEPHENS & 49015 & UT & EMERY \\
\hline & $T X$ & MILAM & 48431 & $T X$ & STERL ING & 49017 & UT & GARF IELD \\
\hline & $T X$ & MILLS & 48433 & $T X$ & STONEWALL & 49019 & UT & GRAND \\
\hline
\end{tabular}




\begin{tabular}{|c|c|c|c|c|c|}
\hline +9021 & UT & IRON & 51027 & VA & BUCHANAN \\
\hline 49023 & UT & JUAB & 51029 & VA & BUCK INGHAM \\
\hline 49025 & UT & KANE & 51031 & VA & CAMPBELL \\
\hline 49027 & UT & MILLLARD & 51033 & VA & CAROL INE \\
\hline 49029 & UT & MORGAN & 51035 & VA & CARROLL \\
\hline 49031 & UT & PIUTE & 51036 & VA & CHARLES CI \\
\hline 49033 & UT & $\mathrm{RICH}$ & 51037 & VA & CHARLOTTE \\
\hline 49035 & UT & SALT LAKE & 51041 & VA & CHESTERF IE \\
\hline 49037 & UT & SAN JUAN & 51043 & VA & CLARKE \\
\hline 49039 & UT & SANPETE & 51045 & VA & CRAIG \\
\hline 49041 & UT & SEVIER & 51047 & VA & CULPEPER \\
\hline 49043 & UT & SUMMI T & 51049 & VA & CUMBERLAND \\
\hline 49045 & UT & TOOELE & 51051 & VA & DICKENSON \\
\hline 49047 & UT & UINTAH & 51053 & VA & DINWIDDIE. \\
\hline 49049 & UT & UTAH & 51057 & VA & ESSEX \\
\hline $4905 i$ & UT & WASATCH & 51059 & VA & FAIRFAX \\
\hline 49053 & UT & WASHINGTON & 51061 & VA & FAUQU IER \\
\hline 49055 & UT & WAYNE & 51063 & VA & FLOYD \\
\hline 49057 & UT & WEBER & 51065 & VA & FLUVANNA \\
\hline 49999 & UT & $(A L L)$ & 51067 & VA & FRANKL IN \\
\hline 50000 & VT & (UNSPEC IF) & 51069 & VA & FREDER i CK \\
\hline 50001 & VT & ADD ISON & 51071 & VA & GILES \\
\hline 50003 & $V T$ & BENN INGTON & 51073 & VA & GLOUCESTER \\
\hline 50005 & $\mathrm{~V} T$ & CALEDON I A & 51075 & VA & GOOCHLAND \\
\hline 50007 & VT & CHITTENDEN & 51077 & VA & GRAYSON \\
\hline 50009 & VT & ESSEX & 51079 & VA & GREENE \\
\hline 500 & VT & FRANKL IN & 51081 & VA & GREENSVILL \\
\hline 50013 & VT & GRAND I SLE & 51083 & VA & HAL IFAX \\
\hline 50015 & VT & LAMO I LLE & 51085 & VA & HANOVER \\
\hline 50017 & VT & ORANGE & 51087 & VA & HENR I CO \\
\hline 50019 & VT & ORLEANS & 51089 & VA & HENRY \\
\hline 50021 & VT & RUT.LAND & 51091 & VA & HI GH ILAND \\
\hline 50023 & $\vee T$ & WASHINGTON & 51093 & VA & ISLE OF WI \\
\hline 50025 & VT & WINDHAM & 51095 & VA & JAMES CITY \\
\hline 50027 & VT & WINDSOR & 97 & VA & KING AND Q \\
\hline $50 s$ & VT & $(A L L)$ & 599 & VA & K.ING GEORG \\
\hline 51000 & VA & (UNSPEC I F) & 51101 & VA & KING WILL I \\
\hline 51001 & VA & ACCOMACK & 03 & VA & LANCASTER \\
\hline 510 & VA & ALBEMARLE & 51105 & VA & LEE \\
\hline 51005 & VA & ALLEGHANY & 51107 & VA & LOUDOUN \\
\hline 510 & VA & AMEL I A & 51109 & VA & LOUISA \\
\hline 51009 & $\checkmark A$ & AMHERST & & VA & LUNENBERG \\
\hline & VA & APPOMATTOX & 51113 & VA & MADISON \\
\hline 510 & VA & ARL INGTON & 51115 & VA & MATHEWG \\
\hline 510 & VA & AUGUSTA & 51117 & VA & MECKLENBUR \\
\hline & VA & RATH & 51119 & VA & MIDLLESEX \\
\hline & VA & BËDF ORD & 51121 & VA & MONTGOMERY \\
\hline & VA & BLAND & 51123 & VA & NANSEMOND \\
\hline 510 & VA & BOTETOURT & 51125 & VA & NEL.SON \\
\hline & VA & BRUNSW I CK & 51127 & VA & NEW KENT \\
\hline
\end{tabular}

51131 VA NORTHAMPTO

51133 VA NORTHUMBER

51135 VA NOTTOWAY

51.137 VA ORANGE

51139 VA PAGE

51141 VA PATRICK

51143 VA PITTSYLVAN

51145 VA POWHATAN

51147 VA PRINCE EDW

51149 VA PRINCE GEO

51153 VA PRINCE WIL

51155 VA PULASKI

51157 VA RAPPAHANNO

51159 VA RICHMOND

51161 VA ROANOKE

51163 VA ROCKBRIDGE

51165 VA ROCK INGHAM

51167 VA RUSSELL

51169 VA SCOTT

51171 VA SHENANDOAH

51173 VA SMYTH

51175 VA SOUTHAMPTO

51177 VA SPOTSYLVAN

51179 VA STAFFORD

51181 VA SURRY

51183 VA SUSSEX

51185 VA TAZEWELL

51187 VA WARREN

51191 VA WASHINGTON

51193 VA WESTMORELA

51195 VA WISE

51197 VA WYTHE

51199 VA YORK

51510 VA ALEXANDRIA

51515 VA BEDFORD CI 51520 VA BRISTOL CI 51530 VA BUENA VIST 51540 VA CHARLOTTES 51550 VA CHESAPEAKE 51560 VA CLIFTON FO 51570 VA COLONIAL H 51580 VA COVINGTON 51590 VA DANVILLE C 51595 VA EMPORIA CI 51600 VA FAIRFAX CI 51610 VA FALLS CHUR 51620 VA FRANKLIN C 51630 VA FREDERICKS 51640 VA GALAX CITY 51650 VA HAMPTON CI 
51660 VA HARRISONBU 51670 VA HOPEWELL C 51678 VA LEXINGTON 51680 VA LYNCHBURG 51690 VA MARTINSVIL 51700 VA NEWPORT NE 51710 VA NORFOLK CI 51720 VA NORTON CIT 51730 VA PETERSBURG 51740 VA PORTSMOUTH 51750 VA RADFORD CI 51760 VA RICHMOND C 51770 VA ROANOKE CI 51775 VA SALEM CITY 51780 VA SOUTH BOST 51790 VA STAUNTON C 51800 VA SUFFOLK CI 51810 VA VIRGINIA B 51820 VA WAYNESBORO 51830 VA WILLIAMSBU 51840 VA WINCHESTER 51999 VA (ALI..) 52000 VI VIRGIN ISL 52001 VI ST CROIX + 52003 VI ST JOHN + 52005 VI ST THOMAS+ 52999 VI (ALL) 53000 WA (UNSPEC IF) 53001 WA ADAMS 53003 WA ASOTIN 53005 WA BENTON 53007 WA CHELAN 53009 WA CLALLAM 53011 WA CLARK 53013 WA COLUMBIA 53015 WA COWLITZ 53017 WA DOUGLAS 53019 WA FERRY 53021 WA FRANKLIN 53023 WA GARF IELD 53025 WA GRANT 53027 WA GRAYS HARB 53029 WA ISLAND 53031 WA JEFFERSON 53033 WA KING 53035 WA KITSAP 5.30 .37 WA KITTITAS 53039 WA KLICKITAT 53041 WA LEWIS 53043 WA LINCOLN

\begin{tabular}{|c|c|c|}
\hline $30+5$ & WA & MASON \\
\hline 53047 & WA & OKANOGAN \\
\hline 53049 & WA & PAC IF IC \\
\hline 53051 & WA & PEND ORE IL \\
\hline 3053 & WA & PIERCE \\
\hline 53055 & WA & SAN JUAN \\
\hline 53057 & WA & SKAG I T \\
\hline 3059 & WA & SKAMAN I A \\
\hline 53061 & |n|A & SNOHOMISH \\
\hline 53063 & WA & SPOKANE \\
\hline 33065 & WA & STEVENS \\
\hline 53067 & WA & THURSTON \\
\hline 53069 & WA & WAHK I AKUM \\
\hline 3071 & WA & WALLA !.JAL.L \\
\hline 53073 & WA & WHATCOM \\
\hline 53075 & WA & WH I TMAN \\
\hline 3077 & WA & YAK IMA \\
\hline 53999 & WA & (ALL) \\
\hline 54000 & WV & (UNSPECIF) \\
\hline 54001 & WV & BARBOUR \\
\hline 54003 & WV & BERKELEY \\
\hline 54005 & WV & BOONE \\
\hline 54007 & WV & BRAXTON \\
\hline 309 & WV & BROOKE \\
\hline 54011 & WV & CABELL \\
\hline 54013 & WV & CALHOUN \\
\hline 54015 & WV & CLAY \\
\hline 54017 & WV & DODDR I DGE \\
\hline 540119 & WV & FAYETTF \\
\hline 54021 & WV & GILMER \\
\hline & WV & GRANT \\
\hline 54025 & WV & GREENBR IER \\
\hline 27 & WV & HAMPSHIRE \\
\hline 9 & WV & HANCOCK \\
\hline 54 & WV & HARDY \\
\hline 54033 & WV & HARR I SON \\
\hline 54035 & WV & JACKSON \\
\hline 540 & WV & JEFFERSON \\
\hline 54039 & WV & KANAWHA \\
\hline & WV & LEWIS \\
\hline & WV & LINCOLN \\
\hline & WV & LOGAN \\
\hline 54047 & WV & MC DOWELL \\
\hline 54049 & WV & MARION \\
\hline 54051 & WV & MARSHALL \\
\hline 54053 & WV & MASON \\
\hline & WV & MERCER \\
\hline & WV & MINERAL \\
\hline 59 & WV & MINGO \\
\hline & & \\
\hline
\end{tabular}

54063 WV MONROE 54065 WV MORGAN 54067 WV NICHOLAS 54069 WV OHIO 54071 WV PENDLETON 54073 WV PLEASANTS 54075 WV POCAHONTAS 54077 WV PRESTON 54079 IAIV PIITNAMM 54081 WV RALEIGH 54083 WV RANDOLPH 54085 WV RITCHIE 54087 WV ROANE 5'1080 WV SUMMERS 54091 WV TAYLOR 54093 WV TUCKER 54095 WV TYLER 54097 WV UPSHUR 54099 WV WAYNE 54101 WV WEBSTER 54103 WV WETZEL 54105 WV WIRT 54107 WV WOOD 54109 WV WYOMING 54999 WV (ALL) 55000 WI (UNSPECIF) 55001 WI ADAMS 55003 WI ASHLAND $55005 W I$ BARRON 55007 WI BAYF IELD 55009 WI BROWPN 55011 WI BUFFALO 55013 WI BURNETT 55015 WI CALUMET 55017 WI CHIPPEWA 55019 WI CLARK 55021 WI COLUMBIA 55023 WI CRAWFORD 55025 WI DANE 55027 WI DODGE 55029 WI DOOR 55031 (n) I DOIJGLAS 55033 WI DUNN 55035 WI. EAU C!_AIRE 55037 WI FLORENCE 55039 WI FOND DU LA 55041 WI FOREST 55043 WI GRANT 55045 WI GREEN 55047 WI GREEN LAKE 
55049 WI IOWA

55051 WI IRON

55053 WI JACKSON

55055 WI JEFFERSON

55057 WI JUNEAU

55059 WI KENOSHA

55061 WI KEWAUNEE

55063 WI LA CROSSE

55065 WI LAFAYETTE

55067 WI LANGLADE

55069 WI LINCOLN

55071 WI MANITOWOC

55073 WI MARATHON

55075 WI MARINETTE

55077 WI MARQUETTE

55078 WI MENOMINEE

55079 WI MILWAUKEE

55081 WI MONROE

55083 WI OCONTO

55085 WI ONEIDA

55087 WI OUTAGAMIE

55089 WI OZAIJKEE

55091 WI PEPIN

55093 WI PIERCE

55095 WI POLK

55097 WI PORTAGE

55099 WI PRICE

55101 WI RACINE

55103 WI RICHLAND

55105 WI ROCK

55107 WI RUSK

55109 WI ST CROIX

55111 WI SAUK

55113 WI SAWYER

55115 WI SHAWANO

55117 WI SHEBOYGAN

55119 WI TAYLOR

55121 WI TREMPEALEA

55123 WI VERNON

55125 WI VILAS

55127 WI WALWORTH

55129 WI WASHBURN

55131 WI WASHINGTON

55133 WI WAUKESHA

55135 WI WAUPACA

55137 WI INALISHARA

55139 WI WINNEBAGO

55141 WI WOOD

55999 WI (ALL)

56000 WY (UNSPECIF)

\begin{tabular}{|c|c|c|c|c|c|}
\hline 56001 & WY & ALBANY & 75300 & US & MARSHALL \\
\hline & WY & BIG HORN & 75301 & US & ARNO \\
\hline 56005 & WY & CAMPBELL & 75303 & US & BIKINI \\
\hline 56007 & WY & CARBON & 75305 & US & ENI WETOK \\
\hline 56009 & WY & CONVERSE & 75307 & US & JALVIT \\
\hline 56011 & WY & CROOK & 75309 & US & KWAJALE IN \\
\hline 56013 & WY & FREMONT & 75311 & US & MAJURO \\
\hline 56015 & WY & GOSHEN & 75313 & US & NAMU \\
\hline & WY & HOT SPRING & 75319 & US & OTHER 753 \\
\hline 56019 & WY & JOHNSON & 76000 & US & MISC CARIB \\
\hline 56021 & WY & LARAMIE & 76001 & US & NAVASSA IS \\
\hline & Wr & LINCOLN & 76003 & US & QUI TO SUEN \\
\hline $560 \tilde{5}$ & WY & NATRONA & 76005 & US & RONCADOR C \\
\hline 56027 & WY & NI OBRARA & 76007 & US & SERRANA B. \\
\hline 55029 & WY & PARK & 76009 & US & SERRANILLA \\
\hline & WY & PLATTE & 77000 & US & MISC PACIF \\
\hline 56033 & WY & SHERIDAN & 77001 & US & KINGMAN R. \\
\hline 035 & WY & SUBLETTE & 77003 & US & BAKER I . \\
\hline 037 & WY & SWEETWATER & 77005 & US & HOWLAND I \\
\hline 139 & WY & TETON & 77007 & US & JARVIS I. \\
\hline 56041 & WY & UINTA & 77009 & US & PALMYRA A. \\
\hline 5043 & WY & WASHAKIE & 78000 & VI & VIRGIN IS. \\
\hline 5045 & WY & WESTON & 79001 & US & WAKE I. \\
\hline 56999 & WY & $(A L L)$ & 80103 & FO & ANT IGUA \\
\hline 60000 & AS & AM. SAMOA & 80106 & FO & AFGHANIST \\
\hline 51000 & $C Z$ & CANAL ZONE & 80107 & FO & ALGERIA \\
\hline 00 & US & CANTON/END & 80112 & FO & ALBAN I A \\
\hline 62001 & US & CANTON I. & 80114 & FO & ANDORRA \\
\hline 62003 & US & ENDERBURY & 80115 & FO & ANGOLA \\
\hline 66000 & GU & GUAM & 80118 & FO & ARGENT I NA \\
\hline 670 & US & JOHNSTON A & 80119 & FO & AUSTRAL I A \\
\hline 71001 & US & MIDWAY IS. & 80121 & FO & AUSTRIA \\
\hline 72000 & PR & PUERTO RIC & 80122 & FO & ANGUI LLA \\
\hline 75000 & US & TRUST TERR & 80125 & FO & ANTARCT ICA \\
\hline 00 & US & CAROL INE I & 80201 & FO & BAHRA IN \\
\hline & US & KUSAIE & 80202 & ro & BARBADOS \\
\hline & US & NOMOI & 80203 & FO & BOTSWANA \\
\hline 75 & US & PALAU & 80204 & FO & BERMUDA \\
\hline & US & SANSOROL & 80205 & FO & BELGIUM \\
\hline & US & SENYAVIN & 80206 & FO & BAHAMAS \\
\hline & US & TRUK & 80207 & FO & BANGLADESH \\
\hline & US & UL I TH I & 80208 & FO & BEL I ZE \\
\hline & US & YAP & 80212 & FO & BOL IV I A \\
\hline & US & OTHER 751 & 80213 & FO & BURMA \\
\hline & US & MARIANAS I & 80216 & FO & SOLOMON IS \\
\hline & US & GUAM & 80218 & FO & BRAZIL \\
\hline & US & ROTA & 80220 & FO & BHUTAN \\
\hline & US & SAIPAN & 80221 & FO & BULGARIA \\
\hline & US & TINIAN & 80222 & FO & BOUVETOYA \\
\hline & US & OTHER 752 & 80224 & & BRUNE I \\
\hline
\end{tabular}

75300 US MARSHALL I

75305 US ENIWETOK

75307 US JALVIT

75309 US KWAJALEIN

75311 US MAJURO

75313 US NAMU

5319 US OTHER 753

76000 US MISC CARIB

76001 US NAVASSA IS

76003 US QUITO SUEN

6005 US RONCADOR C

76007 US SERRANA B.

77001 US KINGMAN R.

77003 US BAKER I.

77005 US HOWLAND I.

77007 US JARVIS I .

78000 VI VIRGIN IS.

79001 US WAKE I.

80103 FO ANTIGUA

IST.

80107 FO ALGERIA

80112 FO ALBANIA

80119 FO AUSTRALIA

80125 FO ANTARCTICA

80204 FO BERMUDA

80205 FO BELGIUM

80206 FO BAHAMAS

80207 FO BANGLADESH

80208 FO BEL I ZE

80216 FO SOLOMON IS

80218 FO BRAZIL

802ट2 FO BOUVETOYA

80224 FO BRUNE 


\begin{tabular}{|c|c|c|c|c|c|}
\hline $\begin{array}{l}80225 \\
80226\end{array}$ & $\begin{array}{l}\text { FO } \\
\text { FO }\end{array}$ & $\begin{array}{l}\text { BURUND I } \\
\text { BERL IN }\end{array}$ & $\begin{array}{l}80718 \\
80719\end{array}$ & $\begin{array}{l}\text { FO } \\
\text { FO }\end{array}$ & $\begin{array}{l}\text { GREECE } \\
\text { GILBERT IS }\end{array}$ \\
\hline $\begin{array}{l}80 \text { 담 } \\
80301\end{array}$ & FO & CANADA & 80720 & FO & GUATEMALA \\
\hline 80302 & $\mathrm{FO}$ & CAMBOD I A & 80722 & FO & GUINEA \\
\hline 0304 & FO & CHAD & 80725 & FO & GUYANA \\
\hline 80305 & FO & SR I LANKA & 80726 & FO & GAZA STRIP \\
\hline 80306 & $\mathrm{FO}$ & CONGO & 80801 & $\mathrm{FO}$ & HA IT I \\
\hline 80307 & FO & ZAIRE & 80811 & FO & HONG KONG \\
\hline 80308 & FO & CHINA (C) & 80813 & FO & HEARD / MAC \\
\hline 80309 & FO & CHILE & 80815 & FO & HONDURAS \\
\hline 80310 & FO & CAYMAN IS & 80821 & FO & HUNGARY \\
\hline & FO & cocos is & 80903 & FO & ICELAND \\
\hline 80313 & FO & CAMEROON & 80904 & FO & I NDONES I A \\
\hline 80314 & $\mathrm{FO}$ & COMOROS & 80914 & FO & INDI A \\
\hline & $\mathrm{FO}$ & COLUMBIA & 80915 & FO & BR. INO. O \\
\hline 80319 & $\mathrm{FO}$ & COSTA RICA & 80918 & $F O$ & IRAN \\
\hline 80320 & FO & CENT. AFR. & 80919 & FO & I SRAEL \\
\hline 80321 & FO & CUBA & 80920 & FO & I TALY \\
\hline & $\mathrm{FO}$ & CAPE VERDE & 80922 & $\mathrm{FO}$ & I VORY COA. \\
\hline 80323 & FO & COOK IS & 80925 & FO & I-S DMZ \\
\hline 80325 & FO & CYPRUS & 80926 & FO & IRAQ \\
\hline 805 & FO & CZECHOSLO. & 81001 & FO & JAPAN \\
\hline 80401 & FO & DENMIARK & 81013 & FO & JAMA ICA \\
\hline $80+13$ & FO & BEN IN & 81015 & FO & JORDAN \\
\hline 80415 & FO & DOMINICA & 81019 & FO & SVALBARD + \\
\hline & FO & DOM. REP. & 1105 & FO & KENYA \\
\hline 80503 & FO & ECUADOR & 114 & FO & KOREA (N) \\
\hline 80507 & FO & EGYPT & 81119 & FO & KOREA (S) \\
\hline 80 & FO & I RELAND & 81120 & FO & CHRISTMAS \\
\hline 80511 & FO & EQ. GUINEA & 81121 & FO & KUWA I T \\
\hline & $\mathrm{FO}$ & EL SALVAD. & 81201 & FO & LAOS \\
\hline & FO & ETHIOPIA & 81205 & FO & LEBANON \\
\hline 806 & FO & FALKLAND I & 81209 & FO & L IBER I A \\
\hline 80607 & FO & FR. GUIANA & 812.19 & FO & LIECHTENS. \\
\hline 806 & FO & F INLAND & 81220 & FO & LESOTHO \\
\hline & FO & $\mathrm{FIJI}$ & 81221 & $\mathrm{FO}$ & LUXËMBOUARG \\
\hline $80 \theta$ & FO & FAROE IS. & 81225 & FO & LIBYA \\
\hline & FO & FR. POLYN. & 81301 & $\mathrm{FO}$ & MADAGASCAR \\
\hline & FO & FRANCE & 81302 & $\mathrm{FO}$ & MART I N I QUE \\
\hline & FO & FR. $S+A$ LS & 81303 & FO & MACAO \\
\hline & FO & AFARS/ISS. & 81307 & FO & MONGOL I A \\
\hline & $F O$ & GAMB I A & 81308 & FO & MONTSERRAT \\
\hline & FO & GABON & U1 ડ́U' & 100 & MALAW I \\
\hline 80703 & FO & GERMANY (E & 81312 & FO & MAL I \\
\hline & FO & GERMANY (W & 81314 & FO & MONACO \\
\hline & FO & GHANA & 81315 & FO & MOROCCO \\
\hline & $\mathrm{FO}$ & GIBRAL TAR & 81316 & FO & MAURITIUS \\
\hline & $F$ & GRENADA & 81318 & FO & MAUR I TAN I A \\
\hline & & GREENLAND & 81320 & $\mathrm{FO}$ & MALTA \\
\hline & & GUADE & & & \\
\hline
\end{tabular}

81322 FO MALDIVES

81324 FO MEXICO

81325 FO MALAYSIA

81326 FO MOZAMBIQUE

81401 FO NETH. ANT.

81403 FO NEW CALED.

81405 FO NIUE

81406 FO NORFOLK I

81407 FO NIGER

81408 FO NEW HEBRI .

81409 FO NIGERIA

81412 FO NETHERLAN.

81415 FO NORWAY

81416 FO NEPAL

81418 FO PNAURU

81419 FO SURINAM

81421 FO NICARAGUA

81426 FO NEW ZEALA.

81601 FO PARAGUAY

81603 FO PITCAIRN

81605 FO PERU

81606 FO PARACEL IS

81607 FO SPRATLY IS

81611 FO PAKISTAN

81612 FO POLAND

81614 FO PANAMA

81615 FO PORTUGAL

81616 FO PAPUA

81621 FO GUINEA-BI .

81701 FO QATAR

$818 U 5$ FU RËUNION

81808 FO RHODESIA

81815 FO -ROMANIA

81816 FO PHILIPPIN. 81823 FO RWANDA

81901 FU SAUÜI ARA. 81902 FO ST. PIERRE 81903 FO SAN KITTS 81905 FO SEYCHELLES 81906 FO S. AFRICA 81907 FO SENEGAL 81908 FO ST. HELENA $819 ! 2$ FU SIERRA LE. 81913 FO SAN MARINO 81914 FO SINGAPORE 81915 TO SOMAL I A 81916 FO SPAIN 81920 FO ST. LIIIC IA 81921 FO SUDAN 81923 FO SWEDEN 


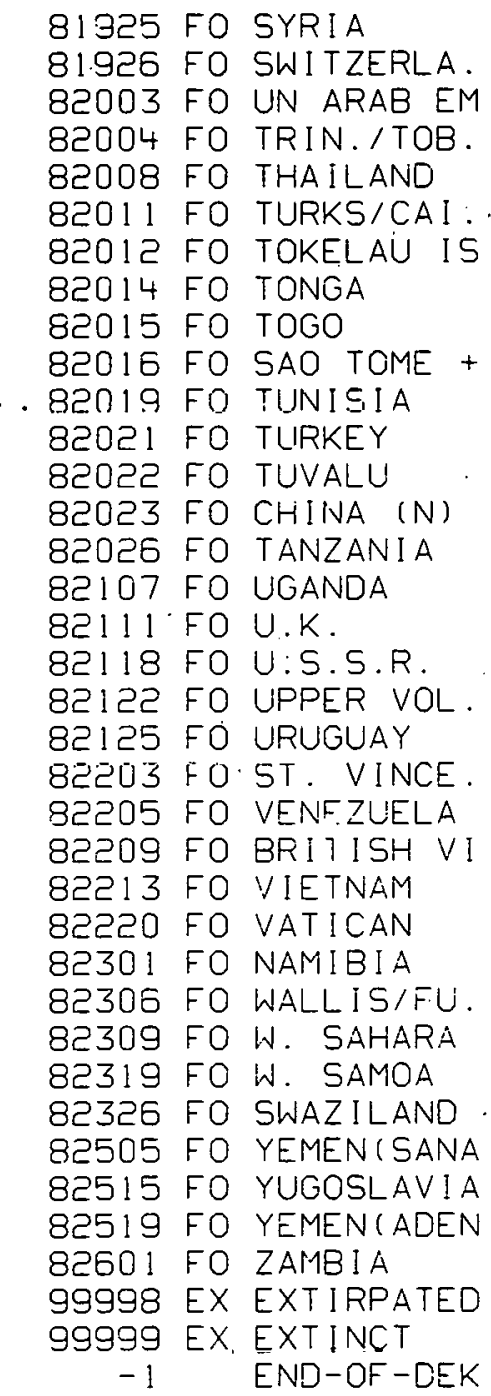




\section{REFERENCES}

(1). National Bureau of Standards (1973) "Counties and County Equivalents of the United States", Federal Information Processing Standards, FIPS PUB 6-2, American National Standard X3.31-1973, 15 September 1973.

(2). National Bureau of Standards (1970) "States and Outlying Areas of the United States", Federal Information Processing Standards, FIPS PUB 5-1, 15 June 1970.

(3). National Bureau of Standards (1976) "Countries, Dependencies, and Areas of Special Sovereignty", Federal Information Processing Standards, FIPS PUB 10-2, 15 November 1976

(4). Little, Elbert L., Jr., Roy O. Woodbury, and Frank H. Wadsworth (1974) Trees of Puerto Rico and the Virgin Islands, Second Volume, Agriculture Handbook No. 449, U.S. Department of Agriculture, Forest Service, Washington, DC, September 1974, page 3 . 